\title{
A Review on Impact of Mining and Mineral Processing Industries through Life Cycle Assessment
}

Shahjadi Hisan Farjana ${ }^{a}$, Nazmul Huda ${ }^{a, n}$, M. A. Parvez Mahmud ${ }^{a}$, R. Saidur ${ }^{\text {bcc }}$

${ }^{a}$ School of Engineering, Macquarie University, Sydney, NSW-2109, Australia

${ }^{\mathrm{n}}$ Corresponding Author: Email: nazmul.huda@mq.edu.au, Phone: +61 0298502249

${ }^{b}$ Research Centre for Nano-Materials and Energy Technology (RCNMET), School of Science and Technology, Sunway University, No. 5, Jalan Universiti, Bandar Sunway, Petaling Jaya, 47500 Selangor Darul Ehsan, Malaysia

${ }^{c}$ Department of Engineering, Lancaster University, LA1 4YW,UK 


\title{
A Review on Impact of Mining and Mineral Processing Industries through Life Cycle Assessment
}

\author{
Shahjadi Hisan Farjana ${ }^{a}$, Nazmul Huda ${ }^{\text {a, n }}$, M. A. Parvez Mahmud ${ }^{a}$, R. Saidur ${ }^{\text {b,c }}$ \\ ${ }^{a}$ School of Engineering, Macquarie University, Sydney, NSW-2109, Australia \\ ${ }^{\text {n }}$ Corresponding Author: Email: nazmul.huda@mq.edu.au, Phone: +61 0298502249 \\ ${ }^{\mathrm{b}}$ Research Centre for Nano-Materials and Energy Technology (RCNMET), School of Science and Technology, Sunway \\ University, No. 5, Jalan Universiti, Bandar Sunway, Petaling Jaya, 47500 Selangor Darul Ehsan, Malaysia \\ ${ }^{\mathrm{c}}$ Department of Engineering, Lancaster University, LA1 4YW,UK
}

\begin{abstract}
:
This paper analysed and summarised the significant research outputs published on the environmental impact assessment of mining and mineral processing industries through life cycle assessment. The paper presents valuable insights in identifying the gaps, where should the focus be in the mining and mineral processing industries for a sustainable future. Mining and mineral processing industries has been the key focus of research in many countries due to its increasing sustainability concerns that affects global warming and climate change. Use of heavy equipment that consumes electrical energy, mechanical energy, and enormous amount of process heat is a key contributor of the overall impacts in the industry. Due to the use of heavy equipment and associated energy consumption, these industrial sector contribute notably to global warming, human health, ecosystems, and resources. Among the various environmental impact assessment tools which are widely used to identify sustainability indicators, life cycle assessment (LCA) is a well justified approach among the practitioners and researchers. Though state of the art technological tools and resources are being used now a days, there is still a research gap in identifying the key mining processes which need to be the focus of attention. Renewable energy integration in the mineral processing sector and process heating from green energy sources is becoming the emergent field of research. The review results reveal, the assessment indicators in human health and ecosystems are key factors that are mostly missing in the previous studies which are crucial for people or community living nearby mining area. This review paper identifies the research gaps to the existing literature that can form the base for future research direction in the field of LCA and sustainable energy integration in mining and mineral processing industries.
\end{abstract}

Keywords: Mining, mineral processing, life cycle assessment, environmental impact, energy integration, renewable energy, sustainability.

\section{Introduction}

Mining and mineral processing industries contribute a gigantic share in a nation's economy in addition to supplying the invaluable resources for modern civilization. Most importantly, this sector plays a crucial role in sustainable economic development and overall GDP growth. To keep pace with the growing demand of the sustainable world, World Economic Forum is aiming to make the mining world sustainable by 2050 . There are a few goals which should be achieved, and several industrial mining governing bodies are working to settle those goals. These are drivers of change, transitional areas, resource scenario in future, and action plans. The drivers of change can be classified into five types: environmental, technological, societal, geopolitical, and geographic for the growing need in the environmental effect's management in the field of climate change, biodiversity, and water. World economic forum also outlined the key mining and mineral sectors which are crucial for setting the sustainable development goal by 2050: aluminium, iron, nickel, copper, and zinc mining (Ranängen and Lindman, 2017; WORLD ECONOMIC FORUM, 2015). In line with the economic demand and growth, the environmental effects 
and its consequences are also increasing exponentially. Sustainable development meant to an accord between economic activity and environmental concerns. The goal of sustainable development in mining industries is to increase metal production in such a way that it should ascertain the cost and efficiency, without significantly reducing the potential for future generation. The first step to achieve this goal is to assess the environmental impacts caused by the mining industries for current practices and identify the ways to reduce the environmental effects without compromising the production. According to International Council on Mining and Metals there are ten principals, of which two are directly related to climate change, water, and biodiversity - the considerations of environmental side of sustainable development. According to principle number six, continuous improvement should be pursued in environmental issues like water, climate change, and energy use (Gorman and Dzombak, 2018; Mudd, 2009; Tost et al., 2018).

On the subject of the environmental impacts of mining and mineral processing, it can be generally classified as waste management, acid mine drainage, sedimentation, metals deposition, and biodiversity. The processes produce considerable amount of waste outputs, which depends on the type of mineral to be mined and type of ore deposit. It is very challenging to dispose of such a large amount of wastes from mining and mineral processing which is detrimental for aquatic environment and ecosystems. Water pollution from mining wastes causes acid mine drainage, sedimentation, and deposition of metals. Erosion through waste rock piles and runoff after rainfall increases the sedimentation. Acid mine drainage is another type of serious environmental impacts from mining, which occurs from sulfidic minerals. Contamination of acidic water on surface and groundwater resources threatens the aquatic life and plants. Metals and reagents used for processing the significant amount of minerals are also gets released into the environments, gets mixed, and threatens the life of aquatics and plants. Removing the plants and vegetables from the ore mining area results in deforestation threatens the structure of the species, which is affecting the biodiversity (Cortez-Lugo et al., 2018; Fugiel et al., 2017; International Institute for Environment and Development, 2002).

Though the degree of these environmental impacts varies from one mine to another, from one metal to another metal, and correlates with the volume of production, the need for determining and quantifying the effects caused by the sector is inevitable to identify the key processes/ materials which are accountable for major environmental emissions and impacts. For example, the key processes are power plants used for electricity generation, diesel used for process heat generation, blasting process, or the ore mining (S.H. Farjana et al., 2018a, 2018b, Shahjadi Hisan Farjana et al., 2018a, 2018b). Among the various factors, fossil fuel consumption for electricity generation and process heat generation is the greatest contributor to environmental effects and emissions caused by the mining industries. The form of non-renewable fuels include coal, natural gas, diesel, heavy fuel oil, bitumen which are producing heat and electrical energy. After combustion, fossil fuel generates carbon di-oxides, nitrous oxides, sulphur di-oxides and produces fly ashes which are polluting the environment. Due to the increasing demand for global development, metal exploration is going into deeper of the surface, which also requires heavy equipment to extract lower grade ore minerals. These lower grade metal extractions also demand higher consumption of electricity for more equipment in use. However, increased environmental emission should be diversified in the fields of the environment- global warming, human health, ecosystems, and resources (Shahjadi Hisan Farjana et al., 2018b, 2018a; Farjana et al., 2019a).

In the mineral processing industries, in the last 15 years, there are 40 significant research outputs that are published based on the life cycle assessment of specific metal mining processes or a system of processes. The life cycle assessment (LCA) results vary from one standardised LCA method to another, from one simulation software to another, and from one mining metal to another. Despite all the key factors, the liable processes crucial for environmental emission for each metal is fixed irrespective of the quantification of results. This statement is validated using the review presented in this paper. The main aim of this review paper is to quantify and analyse the past research in LCA of minerals and mining 
processes to fill the knowledge gaps in major mining and mineral processes and materials accountable for environmental impacts from mining, environmental categories to be affected, quantity of emissions, and suggest alternatives to reduce the environmental impacts from the mining processes. Section 2 describes the materials and methods utilised in this review work. Section 3 describes the LCA methods used for life cycle assessment studies in mining and minerals industries. Section 4 comprehensively categorises and describes the LCA works of minerals and mining industries. Section 5 compares and summarises the major materials/processes responsible for environmental emissions from the mining industries, describes the research gaps and future scope till to date in the LCA research area in relation with mining and mineral processing industries. Finally, the paper finishes in Section 6 by providing some concluding remarks.

\section{Materials and Methods:}

As the first step of this systematic review, the relevant and significant research outputs, and the published articles are sorted and classified as part of the material collection process. In total, forty articles are exclusively selected which are focused on the LCA on mining industries. Among which most of the papers were published in Journal of Cleaner Production, International Journal of Life Cycle Assessment, Science of the Total Environment, Resources Conservation and Recycling, Journal of Environmental Management, and Journal of Sustainable Mining. These papers are classified based on the type of metal mining industry under consideration. Overall sixteen mining processes were rigorously studied through life cycle assessment. Those are aluminium ( 3 papers), copper ( 5 papers), coal (4 papers), gold ( 3 papers), iron ( 7 papers), rare earth element ( 2 papers), uranium ( 4 papers), zinc ( 3 papers), nickel (4 papers), cemented carbide ( 1 paper), ferroalloy ( 1 paper), manganese ( 1 paper), magnesium oxide ( 1 paper), and titanium oxides (1 paper).

In the next step, these publications are extensively studied to identify the key criteria's for conducting the comprehensive literature review. This step can be termed as a comprehensive analysis of the existing literature. In this stage, all the publications are studied irrespective of their evaluation methods, goal, and scope of their research. This stage also investigated the common trends and evaluation criteria followed by mining LCA specialists. Furthermore, LCA methods that were considered in those studies are also classified, which is described in Section 3 of this review paper. LCA methods are summarised as their impact assessment methods in practice, system boundary, impact categories in use, general material inputs and outputs, databases, and their functional units.

In the following step, the evaluation categories are selected, and the papers, their methods, and results are sorted based on the evaluation categories. The criteria are selected based on the metals, their general properties, mining processes, system boundary, geographic location, selected environmental impact categories to be assessed, most impactful mining process identification, and key emission materials.

In the last step, materials and their evaluated criteria are scientifically evaluated, presented, and identified the research gaps in these previous research studies. The papers are further studied to find out the research gap on metals which got comparatively lesser attention from LCA practitioners, mining processes which lacks attention, key materials used in mining which are harmful to the environment and suggesting possible solutions to reduce the notable amount of emissions from the mining process or industries.

Figure 1 describes the key steps of the methods utilised to perform this review study. 


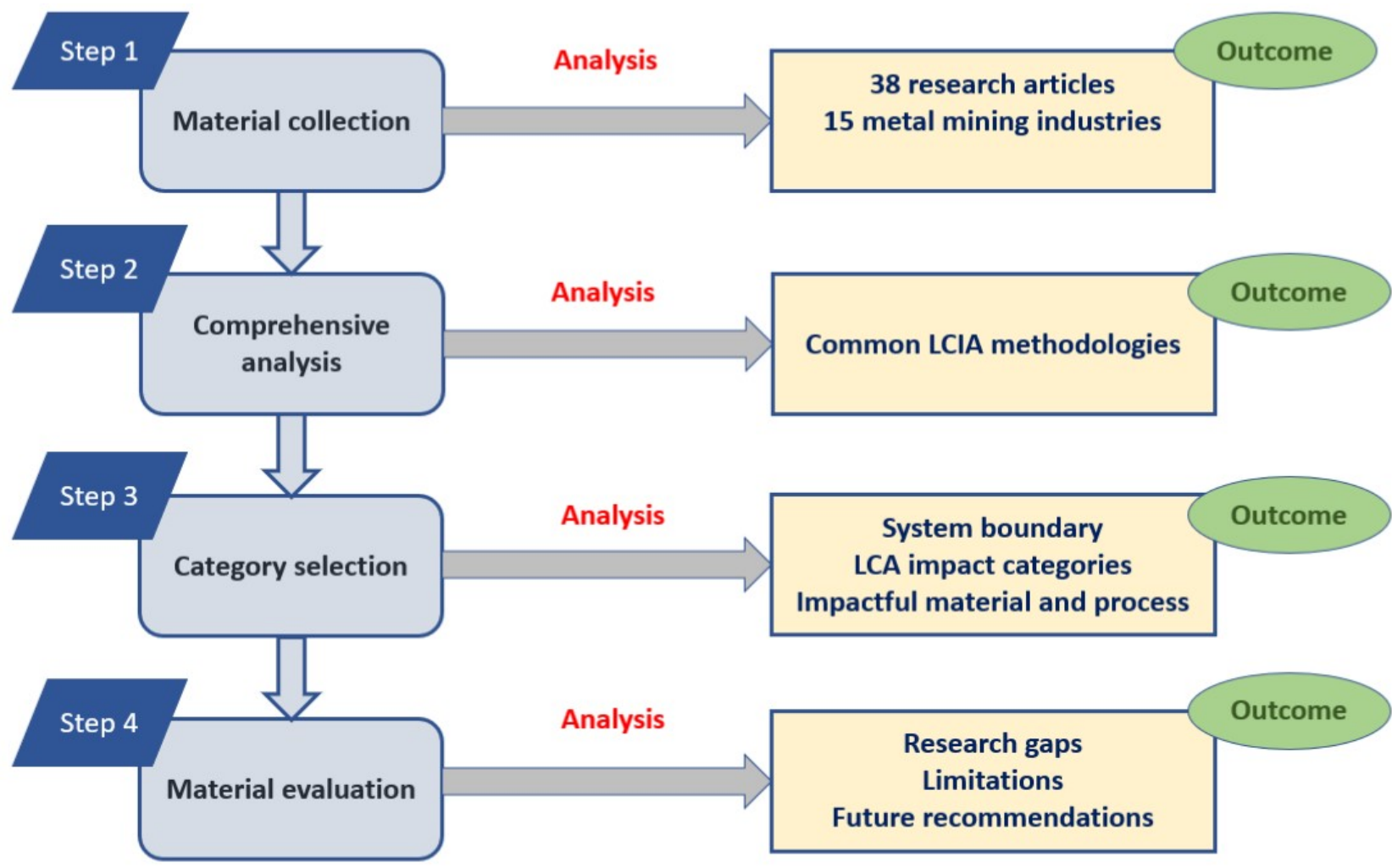

Fig. 1. Steps followed in methods to complete this review.

\section{LCA in mining industries}

This chapter describes the basics of LCA, steps, goal and scope, system boundary, software in use, and methods used for LCA analysis focused in the mining industries so far.

\subsection{Definition and steps in LCA}

Life-cycle assessment is a widely used environmental impact analysis tool which is used for many years in the scientific community to analyse the effects caused by a product, a process, or a system of processes on the environment (Grande et al., 2017). This impact analysis method aims to analyse and classify the environmental emissions based on several categorised and standardised impact assessment categories (Curran, 2012). The major steps in the life cycle assessment comprise of goal and scope definition, LCI (life cycle inventory) modelling, life cycle assessment, and results interpretation. These steps should be followed in each LCA study conducted based on the ISO (International Organization for Standardization) 14040 (Fogler and Timmons, 1998).

\subsection{System Boundary of LCA}

The system boundary followed in a LCA study could be from cradle-to-gate, gate-to-grave, gate-to-gate, or cradle-to-grave (Stewart and Petrie, 2006). The system boundary followed in mining-based LCA studies are cradle-to-gate. Due to the lack of enough data source, it is hard to assume the end-of-life state of the processed metal. Which in turn, restricts the LCA study onto the cradle-to-gate processes (Santero and Hendry, 2016). A complete LCA study in mining comprises of ore mining, concentration and 
beneficiation, extraction, smelting, transportation and refining operations. However, the structure of the system boundary is also dependent on the available datasets, as they are proprietary information.

\subsection{Functional unit and goal of LCA study}

The functional unit in consideration for LCA in mining could be of $1 \mathrm{~kg}$ of selected mineral, or 1 tonne of selected mineral, or mega tonne of that selected mineral. The goal of the LCA works is to analyse the effects of a product or process based on their system boundary and categorise their emissions (Teh et al., 2017): the materials, energy (in the form of renewables and non-renewables, resources, organic and inorganic chemicals are identified as the material inputs in an LCA study. The output product, waste emissions, by-products, and emissions to soil, water, and environment are considered as material or process outputs (Althaus and Classen, 2005).

\subsection{Life cycle inventory datasets}

The life-cycle inventory datasets were collected from several sources like company reports, published literature, renowned databases like EcoInvent, USGS, AusLCI. However, very few datasets are focused on global context. Datasets can be presented as global datasets, regional datasets, or country-specific datasets. For standardising the datasets, the collected sets of data are quantified and aggregated, validated, averaged, and finally represented in the form of mine irrespective datasets. The source of these datasets could be originated from mining company reports, published research works, books, media, and so on (DEE, 2017; EPA, 2018). A global dataset could be generated after data collection from several mining companies of different geographic regions, aggregating, averaging, checking, and data validation. Most of the metal life cycle inventory datasets are regional, which is confusing because technology mix, heat mix, and grid mix vary from one company to another, one country to another, and from one region to another. Another major difference is most of the metals could be mined in alternative routes and alternative techniques. It is hard and not available to get the inventory datasets for each of those mining processes.

In most cases, inventory datasets for subprocesses of the full mining process were available, which made it harder to compare among the mining processes and the metals. Also, metal mining industry datasets are dispersed in different databases which also difficult for researchers to get the life cycle inventory datasets in a go. These differences necessitate the fact that in future it would be highly beneficial to develop global datasets and database containing global metal mining datasets (Althaus et al., 2007; Althaus and Classen, 2005; Hischier et al., 2010; Long et al., 1998; Marguerite et al., 2015; Weidema et al., 2013).

\subsection{Life cycle assessment methods}

The methods to conduct the life cycle assessment are based on ISO 14040 standards. The renowned and widely used LCA methods in mining industries are CML (Centre of Environmental Science of Leiden University of Sweden) method, TRACI (Tool for the Reduction and Assessment of Chemical and other Environmental Impacts) method, ILCD (International Reference Life Cycle Data System) method, CED (Cumulative Energy Demand) method, and IPCC (Intergovernmental Panel on Climate Change) method. These methods vary from one another regarding characterisation, Normalisation and weighting factors, impact categories, and geographic location. The analysed impact categories also vary among the methods. The most common midpoint indicator based (problem-oriented) impact categories are HH (human health, cancer and non-cancer effects), CC (climate change), eutrophication (terrestrial, marine, aquatic), acidification potential, resources depletion, land and water use, and ecotoxicity. The end-point indicator (damage oriented) impact categories are climate change, human health, ecosystems, and resources. These methods are also geography dependent like CML methods are widely used for manufacturing processes 

2015; Hischier et al., 2010; JRC European commission, 2011; Wolf et al., 2012).

The most common life cycle assessment methods utilised in mining industries were ReCiPe method, the IPCC method, and Australian Indicator method. ReCiPe method has 18 midpoints indicator-based categories and three endpoints indicator-based categories. The ReCiPe is the most updated LCA method with a minimum number of indicator scores. ReCiPe method is classified on hierarchies, individualist, and egalitarian method. Most importantly, the ReCiPe method is particularly focused on European geographic continent (Fugiel et al., 2017; Marguerite et al., 2015). Intergovernmental Panel on Climate Change (IPCC) method is specialised in greenhouse gas emissions. This method accesses the GHG effects based on 20 years, 50 years, and 100 years' time span (Hischier et al., 2010).

On the other hand, Australian Indicator method is specialised in materials and processes located in Australian geographic region. According to the best practice guide in life cycle assessment, Australian Indicator method do not contain the toxicity emission factors and the characterisation factors are based on European context, inherited from CML method. So, it is not properly focused on Australian geographic context (Lodhia and Martin, 2014; Marguerite et al., 2015). Center for Methodological Development (CML) method, developed by University of Leiden in Netherland is another well-established LCA method, where the characterisation factors are focused on the average values of global and European geographic context, with no weighting applied on it. So, the regional validity of this method could be considered as global except for the AP and POCF, which are based on European factors. International Reference Life Cycle Data System (ILCD) method is developed by the Joint Research Commission in Europe (JRC) where the impact categories are formed using the base of different renowned methods, IPCC (for climate change in 100 years' time span), USEtox (human toxicity cancer and non-cancer), CML 2002 (resource depletion) and several other methods from literature. This method follows best practice in several impact assessment categories ((JRC), 2012; European Commission -- Joint Research Centre -- Institute for Environment and Sustainability, 2010; JRC European commission, 2011).

The most discussed impact categories are CC/GHG and PED/ TER. AP, MD, waste was also assessed in many literature works, but still, there are hugely lacking regarding environmental impact categories. Due to the lack of complete life cycle inventory datasets, it was also hard to complete full LCA study for metal industries, which could be a great research focus in future. Also, as environmental impacts could not be regional, there is still needing to develop a global LCA method, which would apply to processes or system of processes for any region (Acero et al., 2015; Menoufi, 2011).

Choosing the appropriate LCA method is a crucial step in conducting an LCA. However, this choice is dependent upon several factors such are geography, characterization and Normalisation factors for environment, and industrial sector choice. In mining industries, the most commonly practiced method is the ReCiPe method and ILCD method (discussed in Table 1).

\section{Table 1}

Summary of LCA techniques used in previous studies.

\begin{tabular}{|l|l|l|}
\hline Metal & Method & Impact categories \\
\hline $\begin{array}{l}\text { Aluminium (Farjana et al., 2019a; Nunez } \\
\text { and Jones, 2016; Paraskevas et al., 2016; } \\
\text { Tan and Khoo, 2005) }\end{array}$ & $\begin{array}{l}\text { EDIP, UMIP, ReCiPe, } \\
\text { ILCD, TRACI }\end{array}$ & $\begin{array}{l}\text { GWP, AP, HT, resources, waste, FFD, } \\
\text { EU, ODP, POCP, WF, }\end{array}$ \\
\hline Cemented carbide (Furberg et al., 2019) & & $\begin{array}{l}\text { TE, OD, FEW (Freshwater } \\
\text { ecotoxicity), CC, POF, WD }\end{array}$ \\
\hline $\begin{array}{l}\text { Coal (Adiansyah et al., 2017; Burchart- } \\
\text { Korol et al., 2016; Guimarães da Silva et al., }\end{array}$ & $\begin{array}{l}\text { IPCC, Australian Indicator } \\
\text { ReCiPe, }\end{array}$ & AP, GWP, Resource, waste, dust \\
\hline
\end{tabular}




\begin{tabular}{|c|c|c|}
\hline 2018; Zhang et al., 2018) & & \\
\hline $\begin{array}{l}\text { Copper (Ekman Nilsson et al., 2017; Haque } \\
\text { and Norgate, 2014; Memary et al., 2012; } \\
\text { Norgate, 2001; Northey et al., 2013) }\end{array}$ & $\begin{array}{l}\mathrm{ReCiPe} \\
\text { Indicator }\end{array}$ & GWP, AP, TED, \\
\hline $\begin{array}{l}\text { Ferroalloy (Bartzas and Komnitsas, 2015; } \\
\text { Haque and Norgate, 2013) }\end{array}$ & & GWP, AP, PED \\
\hline $\begin{array}{l}\text { Gold (Chen et al., 2018; Haque and } \\
\text { Norgate, 2014; Norgate and Haque, 2012) }\end{array}$ & $\begin{array}{l}\mathrm{ReCiPe} \\
\text { Indicator }\end{array}$ & $\begin{array}{l}\text { Energy, GWP, water use, waste, TA, HT, } \\
\text { PMF, ME, FD, }\end{array}$ \\
\hline $\begin{array}{l}\text { Iron (Ferreira and Leite, 2015; Gan and } \\
\text { Griffin, 2018; Haque and Norgate, 2015; } \\
\text { Norgate and Haque, 2010) }\end{array}$ & $\begin{array}{l}\text { IPCC, } \quad \text { ReCiPe, } \\
\text { Australian Indicator }\end{array}$ & $\begin{array}{l}\text { GHG, human health, ecosystem, } \\
\text { resources, GER }\end{array}$ \\
\hline Manganese (Westfall et al., 2016) & CML 2001 & GWP, AP, POCP, water use, waste \\
\hline Magnesium oxide (Ruan and Unluer, 2016) & EcoIndicator 99 & Human health, ecosystem, resources, \\
\hline $\begin{array}{l}\text { Nickel (Khoo et al., 2017; Mistry et al., } \\
\text { 2016) }\end{array}$ & $\begin{array}{lr}\text { IMPACT } & 2002+, \\
\text { ReCiPe, } & \text { Australian } \\
\text { Indicator, CML 2001 }\end{array}$ & GWP, PED \\
\hline $\begin{array}{l}\text { Rare earth element (Lima et al., 2018; } \\
\text { Zaimes et al., 2015) }\end{array}$ & $\begin{array}{ll}\text { IMPACT } & 2002+, \\
\text { ReCiPe, CED }\end{array}$ & GER, GWP, ODP, carcinogens \\
\hline Silver (Farjana et al., 2019b, 2019d) & ILCD, CED & GWP, HT. \\
\hline $\begin{array}{l}\text { Steel (Burchart-Korol, 2013; Norgate et al., } \\
\text { 2007; Renzulli et al., 2016) }\end{array}$ & $\begin{array}{l}\text { IPCC, ReCiPe, CED, } \\
\text { ILCD }\end{array}$ & GWP, AP, TED, dust, ODP, PMF \\
\hline $\begin{array}{l}\text { Titanium oxides (Shahjadi Hisan Farjana et } \\
\text { al., 2018a) }\end{array}$ & ILCD, CED & $\begin{array}{l}\text { GWP, AP, FAE, MAE, EU, MRD, LU, } \\
\text { Water, TED }\end{array}$ \\
\hline $\begin{array}{l}\text { Uranium (Shahjadi Hisan Farjana et al., } \\
\text { 2018b; Haque and Norgate, 2014; Norgate } \\
\text { et al., 2014; Parker et al., 2016) }\end{array}$ & $\begin{array}{l}\text { ILCD, Australian } \\
\text { Indicator, CED }\end{array}$ & $\begin{array}{l}\text { GWP, AP, FAE, MAE, EU, MRD, LU, } \\
\text { Water, TED }\end{array}$ \\
\hline $\begin{array}{l}\text { Zinc (Qi et al., 2017; Van Genderen et al., } \\
\text { 2016) }\end{array}$ & ReCiPe, CML 2001 & GWP, AP, EU, POCP, OD, PED, \\
\hline
\end{tabular}

The identification of the best practice methods under different impact categories are discussed below in Table 2. Table 2 also elaborates the quantification techniques for each of the major environmental impact assessment categories.

\section{Table 2}

Quantification and best practice in LCA methods (Marguerite et al., 2015).

\begin{tabular}{|l|l|l|}
\hline Impact categories & Elements used for quantification & Best practice methods \\
\hline Climate change & $\begin{array}{l}\text { Quantification based on the human } \\
\text { activities on climate based on greenhouse } \\
\text { gas emissions. This is most commonly } \\
\text { accounted for carbon dioxide, methane, and } \\
\text { nitrous oxide emissions. }\end{array}$ & $\begin{array}{l}\text { IPCC method to calculate GHG } \\
\text { based on 100 years' emissions. }\end{array}$ \\
\hline Resources depletion & $\begin{array}{l}\text { Quantifies the depletion of natural } \\
\text { resources from the earth, based on on method and ILCD method } \\
\text { concentration of reserve and } \\
\text { deaccumulation rate/quantity of fuels/ ratio } \\
\text { of annual production to available reserve/ } \\
\text { damage to resource based on increased cost } \\
\text { of extraction. }\end{array}$ & $\begin{array}{l}\text { CMLed on concentration of reserve } \\
\text { and deaccumulation rate. }\end{array}$ \\
\hline Eutrophication & $\begin{array}{l}\text { Quantification based on the macro nutrients } \\
\text { released on the environment- air, water, }\end{array}$ & $\begin{array}{l}\text { CML and IMPACT 2002+ which } \\
\text { quantifies based on stoichiometric }\end{array}$ \\
\hline
\end{tabular}


soil. It can be aquatic and terrestrial. Aquatic eutrophication is quantified based on accelerated algae growth, reduced sunlight infiltration and oxygen depletion. Terrestrial eutrophication is quantified based on increase susceptibility of plants to diseases.

Acidification $\quad$ Quantification based on the acidifying
impacts based on when acid precursor compounds are released onto the environment and deposited on land (terrestrial) or water (aquatic). Quantification is mainly based on nitrous oxides, sulphur oxides, sulphuric acid and ammonia.

\begin{tabular}{|c|c|c|}
\hline $\begin{array}{l}\text { Human toxicity and } \\
\text { eco-toxicity }\end{array}$ & $\begin{array}{l}\text { Quantifies the impact of toxicity substance } \\
\text { released on land, water, and environment. } \\
\text { Quantification is based on using pesticides, } \\
\text { heavy metals, hormones, and organic } \\
\text { chemicals. }\end{array}$ & $\begin{array}{l}\text { USEtox, ILCD, ReCiPe, and } \\
\text { IMPACT 2002+. }\end{array}$ \\
\hline $\begin{array}{l}\text { Photochemical } \\
\text { ozone formation }\end{array}$ & $\begin{array}{l}\text { Quantifies the impacts based on impacts } \\
\text { from increase on ozone formation in } \\
\text { troposphere. The main criteria are the } \\
\text { emission of nitrous oxides, carbon } \\
\text { monoxide, and those which impacts on } \\
\text { ozone formation. }\end{array}$ & $\begin{array}{l}\text { CML method, based on simplified } \\
\text { description of atmospheric } \\
\text { transport. }\end{array}$ \\
\hline $\begin{array}{l}\text { Particulate } \\
\text { formation }\end{array}$ & $\begin{array}{l}\text { Quantification is based on the emissions on } \\
\text { air which are harmful for human health. In } \\
\text { different LCIA methods, these are } \\
\text { characterized under different impact } \\
\text { categories. }\end{array}$ & $\begin{array}{l}\text { TRACI as TRACI } \\
\begin{array}{l}\text { method } \\
\text { distinguishes between } \\
\text { different }\end{array} \\
\text { types of emissions. }\end{array}$ \\
\hline Land use & $\begin{array}{l}\text { Quantification is based on the amount of } \\
\text { land use in LCA and its effects on } \\
\text { biodiversity. }\end{array}$ & $\begin{array}{l}\text { Currently no best practice methods } \\
\text { for land use as no single method } \\
\text { quantifies all levels of biodiversity. }\end{array}$ \\
\hline Ozone depletion & $\begin{array}{l}\text { Quantifies the impact based on the } \\
\text { reduction in concentration of ozone. }\end{array}$ & $\begin{array}{l}\text { Ozone depletion factors published } \\
\text { by the World Meteorological } \\
\text { Organizations (WMO). }\end{array}$ \\
\hline Ionizing radiation & $\begin{array}{l}\text { Quantifies the impact of radioactive species } \\
\text { (radionuclides) on air and water. }\end{array}$ & $\begin{array}{l}\text { ILCD or ReCiPe method based on } \\
\text { the quantification of radioactive } \\
\text { impact on human health. }\end{array}$ \\
\hline
\end{tabular}

\subsection{Geographic region under consideration}

Regarding geographic region, a number of studies were focused on different regions, but the most commons were based on two countries - Australia and China. Many research on LCA is being carried out in Australian geographic context- aluminium, coal, copper, ferroalloy, gold, iron, nickel, titanium oxides, and Uranium. For mining in China, LCA on aluminium, coal, iron, and zinc. Impact categories were also different based on metal specific industries, as they were originated from different geographic context and used different LCA methods (Mutchek et al., 2016; Stewart and Petrie, 2006; Teh et al., 2017). 


\subsection{Allocation techniques}

Allocation technique was required in many of the LCA studies which produce a significant number of byproducts. The allocation technique could be of mass-based, economy-based, or can be used as a combination of both mass and economy. The characterisation and normalisation factors for allocation techniques vary among the LCA software like SimaPro or Gabi. According to the trend followed by the metal mining industries, it is best practice to avoid coproduct allocation whenever possible. It was assumed that no products were going outside the system other than the main product. However, in many processes, it cannot be avoided. In those cases, it is better to use the allocation technique focused on both mass and economy, as the mass can vary from one mining company/site to another, production technique could also vary. In addition, results between mass and economy could vary in a large amount. Hence, it is best to calculate using both technique, and then data aggregation and averaging could be done to allocate proper values (Raugei and Ulgiati, 2009; Santero and Hendry, 2016; Weidema and Norris, 2002).

\subsection{Software in use}

The software which was most widely used in mining industries were SimaPro and Gabi. AusLCI database which is integrated with SimaPro software and containing many metal mining LCA datasets focused particularly for Australia made SimaPro a widely accepted choice. The analysis results generated by both SimaPro and Gabi should produce reasonably similar outcome considering similar analysis techniques and databases are used, however, that is also subject to research and validation. There may be some variation among the datasets generated from different companies, the characterisation and normalisation factors would also be different (Goedkoop et al., 2014; Li et al., 2018; Nunez and Jones, 2016; PRé, 2018).

\section{Impact Analysis based on Metal Mining Industries}

This chapter describes the LCA conducted on the key mining and mineral processing industries, their analysis methods, key findings, results, limitations, and future recommendations. The major industries involve aluminum, coal, copper, ferroalloy, gold, iron, nickel, rare earth elements, stainless steel, uranium, and zinc. The last subsection identifies five metals with no or very few research output which are cemented carbide, manganese, magnesium oxide, and titanium oxides.

\subsection{LCA in aluminium mining}

Aluminium is a lightweight and corrosion resistant metal, which are used in automobile industries, aerospace industries, beverage, making alloys, and electronics industries. The top countries which are mining and producing aluminium are China, Russia, Canada, India, Australia. Aluminium production consists of four major steps: bauxite ore mining, alumina production from Bayer process, alumina smelting from Hall Heroult process, and alumina refining. Table 3 describes the major findings and recommendations from the researches conducted related to LCA of this metal.

There are four major studies conducted in the LCA of aluminium production processes. Tan et al. analysed LCA of the aluminium supply chain which consists of the refinery, smelter, and a casting plant. The geographical coverage was Australia, and it was a cradle to gate LCA study. The analysis was done using SimaPro with EDIP (Environmental Design of Industrial Products). The impact categories which were assessed, global warming potential (GWP), acidification potential (AP), human toxicity (HT), resources, built waste. Tan considered four scenarios including the baseline mode of operation, and other 
scenarios were constructed after modifying the scrap metal and red mud. Their results revealed that electricity use in smelting and refining process is mainly responsible for GWP (Global Warming Potential) and HT (Human Toxicity). AP (Acidification Potential) is due to sulfur dioxide $\left(\mathrm{SO}_{2}\right)$ generation from the power plant and transportation system. Their study revealed that reducing the scrap metal and red mud could significantly reduce the impacts from aluminium production (Tan and Khoo, 2005).

Paraskevas et al. analysed aluminium production after comparing electricity mix of 29 countries. Their datasets are originated from EcoInvent and USGS databases whereas analysed using SimaPro software and ReCiPe method. Electricity generated from hydropower, coal, gas, nuclear, biofuel, geothermal, solar are considered there. They assumed that electricity is $100 \%$ grid dependent and not traded among the countries. According to Paraskevas, amount of greenhouse gas emissions from aluminium production is $0.45 \mathrm{Gt} \mathrm{CO}_{2}$ eq. Aluminium production requires $66 \mathrm{MJ}$ energy per $\mathrm{kg}$. More than eighty percent $(80 \%)$ is for electricity generation in Hall Heroult process. They identified that countries with high coal and oilrich mix have higher emission results rather than countries using cleaner technologies. They have also stated that countries with similar electricity mix show similar GHG (Greenhouse Gas Emission) results (Paraskevas et al., 2016).

Another study conducted by Nunez et al. where the datasets are collected by the International Aluminium Institute (IAI) have studied primary aluminium production process and used Gabi software. The geographic region under consideration was global and global minus China. Nunez considered six midpoints indicator-based categories: GWP (global warming potential), AP (acidification potential), FFD (fossil fuel depletion), EU (eutrophication), ODP (ozone depletion potential), POCP (photo-oxidant creation potential), and WSP (water scarcity potential). Their identification also reveals the fact that highest contribution of GHG is from alumina refining and electrolysis process. Direct emissions from the electrolysis process also contribute largely to GHG (Nunez and Jones, 2016). Farjana et al. studied the cradle-to-gate complete LCA of four major steps from the bauxite mining to alumina refining processes. They have also conducted the sensitivity analysis among the quantity of fossil fuel used based on process heat generation. As the study reports, electricity consumption during alumina smelting has the highest impact on environment. Process heat generation has also considerable impact on the environment. The climate change effect from bauxite mining is $0.079 \mathrm{~kg} \mathrm{CO}_{2}$ eq., alumina production is $1.23 \mathrm{~kg} \mathrm{CO}_{2}$ eq., alumina smelting is $10.91 \mathrm{~kg} \mathrm{CO}_{2}$ eq., and alumina refining is $0.27 \mathrm{~kg} \mathrm{CO}_{2}$ eq. (Farjana et al., 2019a)

\section{Table 3}

Summary of the findings and recommendations for LCA of aluminum mining.

\begin{tabular}{|l|l|l|}
\hline Study reference & Key findings & Recommendation \\
\hline $\begin{array}{l}\text { LCA focused on } \\
\text { Australia (Tan and Khoo, } \\
\text { 2005) }\end{array}$ & $\begin{array}{l}\text { Electricity use in smelting and refining } \\
\text { process is mainly responsible for GWP }\end{array}$ & $\begin{array}{l}\text { Reducing the scrap metal and red } \\
\text { mud could significantly reduce } \\
\text { the impacts }\end{array}$ \\
\hline $\begin{array}{l}\text { LCA comparing 29 } \\
\text { countries (Paraskevas et } \\
\text { al., 2016) }\end{array}$ & $\begin{array}{l}\text { Identified that countries with high coal } \\
\text { and oil-rich mix have higher emission } \\
\text { results and countries with similar } \\
\text { electricity mix show similar GHG } \\
\text { results reduce the environmental } \\
\text { impacts from aluminium } \\
\text { production, it should start by } \\
\text { focussing on China due to their } \\
\text { energy mix. All the aluminium } \\
\text { producing countries should focus } \\
\text { on using the cleaner resources. }\end{array}$ \\
\hline $\begin{array}{l}\text { LCA on global aluminum } \\
\text { production (Nunez and } \\
\text { Jones, 2016) }\end{array}$ & $\begin{array}{l}\text { reveals the fact that highest } \\
\text { contribution of GHG is from alumina } \\
\text { refining and electrolysis process. }\end{array}$ & $\begin{array}{l}\text { Due to increased production of } \\
\text { aluminum in China, more LCI } \\
\text { datasets are required for }\end{array}$ \\
\hline
\end{tabular}




\begin{tabular}{|l|l|l|}
\hline & $\begin{array}{l}\text { Direct emissions from the electrolysis } \\
\text { process also contribute largely to GHG }\end{array}$ & $\begin{array}{l}\text { modelling to enhance the } \\
\text { reliability of the impact } \\
\text { assessment about aluminum } \\
\text { production. }\end{array}$ \\
\hline $\begin{array}{l}\text { LCA on global aluminum } \\
\text { production (Farjana et al., } \\
\text { 2019a) }\end{array}$ & $\begin{array}{l}\text { Electricity and process heat } \\
\text { consumption in alumina smelting has } \\
\text { the highest impact. }\end{array}$ & $\begin{array}{l}\text { Alternative energy generation } \\
\text { source and improvement in } \\
\text { energy efficiency would be } \\
\text { beneficial for sustainability. }\end{array}$ \\
\hline
\end{tabular}

\subsection{LCA in coal mining}

Coal is a widely used fossil fuel used for electricity generation or process heat generation. Coal is extracted on the earth crust based on open cast and underground mining. The major miners of coal are Ukraine, Kazakhstan, South Africa, China, United States, and Australia. Coal can be produced from open pit mining or underground mining. There are a few steps involved in coal production while major processes are mining, transportation, and comminution. In the mining step, surface soil is removed for drilling and detonation. Then the inert materials are removed, and coal layers are drilled. Then the coal layers undergo detonation and mined areas are recovered. Then the run of mines undergoes the loading and transportation. The run of mines is then stocked, crushed, and shifted. Table 4 describes the major findings and recommendations from the research conducted related to LCA of this metal.

Korol et al. developed and utilised a computational LCA for coal mining in Poland. They assessed the GHG using the IPCC method (20 years, 100 years, and 500 years). Analysis of damage categories was done using the ReCiPe method. Their study identified that the largest contributor to GHG is fossil fuel and methane emissions for electricity use, processing of waste, heat, and steel supports. Among the three range of years, the highest range of emissions was from 20 years span, that is $85 \mathrm{~kg} \mathrm{CO}_{2}$ eq per $\mathrm{kg}$. In this time frame, highest contributor for GHG is methane emissions which could be generated from electricity, heat and steel support associated with the ventilation process (Burchart-Korol et al., 2016). In another study, Adiansyah et al. compare coal mining tailings management strategies using LCA. They have used hybrid LCA method comprised of Australian Indicator and ReCiPe method. The strategies involved belt press, tailings paste, thickened tailings. They found that electrical energy is the greatest contributor to environmental emissions from coal mining. The analysis is done using three case scenarios- tailings with the low amount of water, tailing paste with much solids, and the base case with high amount of water (Adiansyah et al., 2017). Zhang et al studied opencast coal mining operation in China. The functional unit was 100 ton of coal. The system boundary includes stripping, mining, transportation, processing, and reclamation. The impact categories which were considered: resources, acidification, GWP, waste, and dust. According to Zhang, the most impactful category was dust, followed by GWP and acidification. For 1 ton of coal production, the GWP was $7331.7 \mathrm{~kg} \mathrm{CO} 2$ eq (Zhang et al., 2018). Silva et al. analysed the surface coal mine located in Brazil. Their system boundary includes mining, transportation system, comminution, recovery, production, and final transportation. Their study found that diesel oil is the significant parameter which emits carbon dioxide, methane, and ammonia. They have also conducted a sensitivity analysis based on fugitive emission factors for diesel oil, electricity, and transport (Guimarães da Silva et al., 2018).

\section{Table 4}

Summary of the findings and recommendations for LCA of coal mining.

\begin{tabular}{|l|l|l|}
\hline Study reference & Key findings & Recommendation \\
\hline $\begin{array}{l}\text { LCA for coal mining in } \\
\text { Poland (Burchart-Korol }\end{array}$ & The largest contributor to GHG is & \multicolumn{2}{|c|}{ The impacts can be reduced using } \\
fond methane emissions for & alternative fuels in steel \\
\hline
\end{tabular}




\begin{tabular}{|l|l|l|}
\hline et al., 2016) & $\begin{array}{l}\text { electricity use, processing of waste, } \\
\text { heat }\end{array}$ & $\begin{array}{l}\text { production. Pollution prevention } \\
\text { methods should be applied to } \\
\text { reduce emissions. }\end{array}$ \\
\hline $\begin{array}{l}\text { LCA in respect of } \\
\text { Australia (Adiansyah et } \\
\text { al., 2017) }\end{array}$ & $\begin{array}{l}\text { Electrical energy is the greatest } \\
\text { contributor to environmental emissions } \\
\text { from coal mining }\end{array}$ & $\begin{array}{l}\text { The thickened tailing in the coal } \\
\text { mining tailing management could } \\
\text { reduce the environmental burdens. }\end{array}$ \\
\hline $\begin{array}{l}\text { LCA focused on coal } \\
\text { production in China } \\
\text { (Zhang et al., 2018) }\end{array}$ & $\begin{array}{l}\text { the most impactful category was dust, } \\
\text { followed by GWP and acidification }\end{array}$ & $\begin{array}{l}\text { Increase in tire performance, } \\
\text { transportation efficiency, low- } \\
\text { carbon power development, and } \\
\text { advancement in mining } \\
\text { technology will be beneficial to } \\
\text { reduce the impacts. }\end{array}$ \\
\hline $\begin{array}{l}\text { LCA based on Brazil } \\
\text { (Guimarães da Silva et } \\
\text { al., 2018) }\end{array}$ & $\begin{array}{l}\text { diesel oil is the significant parameter } \\
\text { which emits carbon dioxide, methane, } \\
\text { and ammonia }\end{array}$ & $\begin{array}{l}\text { This work will contribute to the } \\
\text { detailed LCA analysis of coal } \\
\text { mining in Brazil to implement the } \\
\text { measures related to diesel oil. }\end{array}$ \\
\hline
\end{tabular}

\subsection{LCA in copper mining}

Copper is a valuable metal used for their conductivity properties and corrosion resistant properties. They are widely used for electrical wiring, construction, heat exchangers, and electronics. The producers of copper are United States, Chile, and Australia. Copper is extracted using ore mining, beneficiation. If it goes through pyrometallurgical extraction, then it passes through smelting, converting, fire refining, and electrorefining. If the ore goes through hydrometallurgical extraction, then it has leaching, solvent extraction, and electrowinning. Table 5 describes the major findings and recommendations from the research conducted related to LCA of this metal.

Norgate conducted LCA based on pyrometallurgical and hydrometallurgical copper production. They assessed and compared the impacts from process parameters, ore grade, energy consumed for electricity generation, and electricity generation capacity. The assessed impact categories were GWP, AP. They showed that solvent extraction and electrowinning processes of hydrometallurgical copper production has a higher impact over pyrometallurgical copper production (Norgate, 2001). Memary et al. conducted a time series analysis of copper production. They examined the environmental effects from copper mining and smelting from 1940 to 2008 through a novel approach. They had conducted a cradle-to-gate LCA study based on datasets from five Australian copper mine. They showed that carbo footprint from all mines ranged from $800 \mathrm{kt} \mathrm{CO}_{2}$ eq to $1922 \mathrm{kt} \mathrm{CO}_{2}$ eq. They showed that copper mining and milling were the most crucial part to reduce GWP (Memary et al., 2012). Northey et al. conducted LCA of copper mining and stated that average energy intensity ranges from 10 to $70 \mathrm{GJ} / \mathrm{t} \mathrm{Cu}$. GHG ranges from 1 to $9 \mathrm{t}$ $\mathrm{CO}_{2} \mathrm{eq} / \mathrm{t} \mathrm{Cu}$. This large variation was due to the form of copper produced, ore grade, sources of fuel, and electrical energy (Northey et al., 2013). Haque et al. conducted a comparative LCA study among in-situ leaching based production of copper, gold, and uranium. Their study was conducted based on Australian Impact method using SimaPro software. They showed that for copper mining, solvent extraction and electrowinning played a significant role in GHG. For good field related activities, electricity was the main source of GHG and also the sulfuric acid used for leaching (Haque and Norgate, 2014). Nilsson compared the carbon footprint of copper mining based on LCA while the sources are both primary and secondary. The value of carbon footprint ranges from 1.1 to $8.5 \mathrm{~kg} \mathrm{CO}_{2} \mathrm{eq} / \mathrm{kg} \mathrm{Cu}$. The literature shows that it could be 2.1 to $8 \mathrm{~kg} \mathrm{CO}$ eq $/ \mathrm{kg} \mathrm{Cu}$ for primary copper. From the secondary source, the carbon footprint ranges from 0.1 to $1.9 \mathrm{~kg} \mathrm{CO}_{2} \mathrm{eq} / \mathrm{kg} \mathrm{Cu}$. The reason for this wide range of variation was the material quality, the metallurgical process, and transportation distance (Ekman Nilsson et al., 2017). Farjana et al. analyzed the gold-silver-lead-zinc-copper beneficiation process, which summarizes that gold-silver beneficiation has 
greatest impact over the other metal in these joint production which is due to the electricity usage through fossil fuel consumption (Farjana et al., 2019b).

Table 5

Summary of the findings and recommendations for LCA of copper mining.

\begin{tabular}{|l|l|l|}
\hline Study reference & Key findings & Recommendation \\
\hline $\begin{array}{l}\text { LCA on global copper } \\
\text { production (Norgate, } \\
\text { 2001) }\end{array}$ & $\begin{array}{l}\text { solvent extraction and electrowinning } \\
\text { processes of hydrometallurgical copper } \\
\text { production has a higher impact. }\end{array}$ & $\begin{array}{l}\text { They conducted a sensitivity } \\
\text { analysis based on by varying 30\% } \\
\text { of process power consumption } \\
\text { and transport mode and distance, } \\
\text { which indicates in the } \\
\text { improvement } \\
\text { environmental emissions. }\end{array}$ \\
\hline $\begin{array}{l}\text { LCA on Australian } \\
\text { copper mining (Memary } \\
\text { et al., 2012) }\end{array}$ & $\begin{array}{l}\text { copper mining and milling were the } \\
\text { most crucial part to reduce GWP. }\end{array}$ & $\begin{array}{l}\text { The mining production impacts } \\
\text { related to regional energy } \\
\text { consideration should be carefully } \\
\text { considered with the geography. }\end{array}$ \\
\hline $\begin{array}{l}\text { LCA on copper mining } \\
\text { (Northey et al., 2013) }\end{array}$ & $\begin{array}{l}\text { The large variation in GHG was due to } \\
\text { the form of copper produced, ore } \\
\text { grade, sources of fuel, and electrical } \\
\text { energy. }\end{array}$ & $\begin{array}{l}\text { Recommendations made for the } \\
\text { companies for improving mining } \\
\text { datasets through indicating } \\
\text { detailed energy consumption } \\
\text { scenario for each stage of the } \\
\text { metal production. }\end{array}$ \\
\hline $\begin{array}{l}\text { LCA of copper mining in } \\
\text { Australia (Haque and } \\
\text { Norgate, 2014) }\end{array}$ & $\begin{array}{l}\text { For good field related activities, } \\
\text { electricity was the main source of } \\
\text { GHG, and the sulfuric acid used for } \\
\text { leaching. }\end{array}$ & $\begin{array}{l}\text { Electricity generated from the } \\
\text { renewable energy resources such } \\
\text { as solar energy will beneficial for } \\
\text { reducing impacts from in-situ } \\
\text { leaching. }\end{array}$ \\
\hline $\begin{array}{l}\text { LCA of global copper } \\
\text { mine (Ekman Nilsson et } \\
\text { al., 2017) }\end{array}$ & $\begin{array}{l}\text { The reason for this wide range of } \\
\text { variation in GHG was the material } \\
\text { quality, the metallurgical process, and } \\
\text { transportation distance. }\end{array}$ & $\begin{array}{l}\text { In case of the advancement of the } \\
\text { technology for efficient recovery } \\
\text { of metals, the impact will reduce. }\end{array}$ \\
\hline $\begin{array}{l}\text { Gold-silver beneficiation has highest } \\
\text { impact over the other metals }\end{array}$ & $\begin{array}{l}\text { Modification in the electricity grid } \\
\text { mix to enhance the energy } \\
\text { efficiency will be helpful to } \\
\text { reduce environmental burdens. }\end{array}$ \\
\hline
\end{tabular}

\subsection{LCA in ferroalloy mining}

Ferroalloy is iron bearing alloys which also have a higher proportion of metals. They can make alloys including chromium, manganese, molybdenum, silicon. It is mostly found and produced in China, South Africa, Ukraine, Kazakhstan. Table 6 describes the major findings and recommendations from the research conducted related to LCA of this metal.

Haque et al. studied the LCA of ferroalloys. These alloys were iron bearing material alloyed in conjunction with manganese, chromium, silicon, and molybdenum. They studied the environmental impacts in respect of Australia, using the Tasmanian electricity GHG emissions factors. According to their results, GHG was $1.8 \mathrm{t} \mathrm{CO}_{2} \mathrm{eq} / \mathrm{t} \mathrm{FeMn}, 2.8 \mathrm{t} \mathrm{CO}_{2} \mathrm{eq} / \mathrm{t} \mathrm{SiMn}, 3.4 \mathrm{t} \mathrm{CO}_{2} \mathrm{eq} / \mathrm{t} \mathrm{FeSi}, 13.9 \mathrm{t} \mathrm{CO}_{2} \mathrm{eq} / \mathrm{t}$ $\mathrm{FeNi}$, and $3 \mathrm{t} \mathrm{CO}_{2} \mathrm{eq} / \mathrm{t} \mathrm{FeCr}$. This large variation in $\mathrm{GHG}$ was due to their electricity use, fossil fuel consumption, grade of ferroalloys produced (Haque and Norgate, 2013). Bartzas et al. conducted an LCA 


\subsection{LCA in gold mining}

Gold is a precious metal which is popular metal of precious jewellery, currency, or in electronic applications. Australia has the highest amount of gold mine deposit, similar like South Africa, and Russia. From the gold mine, the gold ores are gone through comminution stage comprises of crushing and grinding. If it is refractory ore then consequentially undergoes flotation, roasting, pressure oxidation, biooxidation, regrinding, smelting, and refining. If the gold ore is non-refractory or free-milling ore, then it undergoes extraction, cyanidation (tank or heap), recovery, stripping, electrowinning, smelting, and refining. Table 7 describes the major findings and recommendations from the research conducted related to LCA of this metal.

Norgate et al. analysed gold production processes both from refractory and non-refractory ores. The impact categories under consideration were energy, GHG, water, and waste. They found that refractory ore has the highest impact on mining and comminution stage due to electricity consumption. $61 \%$ of the total GHG is from refractory ores (Norgate and Haque, 2012). Chen et al. analysed the life cycle impact of gold mining processes in China where the impact categories were CC, TAP, HT, PMF (Particulate Matter Formation), FFD (fossil fuel depletion). The analysis was done by midpoint and endpoint-based ReCiPe method. They found that the largest impact is on the metal depletion category from mining due to energy consumption and emissions. For climate change, electricity and diesel were the largest contributors. Climate change impact was $5.55 \mathrm{E} 4 \mathrm{~kg} \mathrm{CO}_{2}$ eq (Chen et al., 2018). Haque et al. conducted a comparative LCA study among in-situ leaching based production of copper, gold, and uranium. Their study was conducted based on Australian Impact method using SimaPro software. They showed that for gold mining, activities relating well field impacts mostly about $39 \%$ of total GHG, where $56 \%$ was from gold extraction and metal production, and 5\% were due to chemical use (Haque and Norgate, 2014). Farjana et al. analyzed the gold-silver-lead-zinc-copper beneficiation process, which summarizes that gold-silver beneficiation has greatest impact over the other metal in these joint production which is due to 
the electricity usage through fossil fuel consumption (Farjana et al., 2019b). Farjana et al. also analyzed the comparative life cycle environmental impacts of gold-silver refining operations where the ore is extracted from co-production of gold-silver and the combined production of gold-silver-lead-zinc-copper. Results from that study showed that gold refining from the gold-silver production have noteworthy environmental impact over the combined production of five metals (Farjana et al., 2019d)

Table 7

Summary of the findings and recommendations for LCA of gold mining.

\begin{tabular}{|c|c|c|}
\hline Study reference & Key findings & Recommendation \\
\hline $\begin{array}{l}\text { LCA on gold mining in } \\
\text { Australia (Norgate and } \\
\text { Haque, 2012) }\end{array}$ & $\begin{array}{l}\text { The refractory ore of gold has the } \\
\text { highest impact on mining and } \\
\text { comminution stage due to electricity } \\
\text { consumption. }\end{array}$ & $\begin{array}{l}\text { Gold mining technological } \\
\text { improvements would be } \\
\text { beneficial for high pressure gas } \\
\text { recovery, leaching, flotation } \\
\text { technologies, gravitational } \\
\text { technologies, etc. to reduce the } \\
\text { environmental impacts. }\end{array}$ \\
\hline $\begin{array}{l}\text { LCA of gold mining in } \\
\text { China (Chen et al., 2018) }\end{array}$ & $\begin{array}{l}\text { The largest impact is on the metal } \\
\text { depletion category from mining due to } \\
\text { energy consumption and emissions. } \\
\text { For climate change, electricity and } \\
\text { diesel were the largest contributors. }\end{array}$ & $\begin{array}{l}\text { Environmental policy suggestions } \\
\text { like increasing the resources } \\
\text { efficiency, adjusting energy } \\
\text { structure, gold recycling, and } \\
\text { ecological compensation approach } \\
\text { would be beneficial for reducing } \\
\text { impacts. }\end{array}$ \\
\hline $\begin{array}{l}\text { LCA of gold mining in } \\
\text { Australia (Haque and } \\
\text { Norgate, 2014) }\end{array}$ & $\begin{array}{l}\text { For gold mining, activities relating } \\
\text { well field impacts mostly about } 39 \% \\
\text { of total GHG, where } 56 \% \text { was from } \\
\text { gold extraction and metal production, } \\
\text { and } 5 \% \text { were due to chemical use. }\end{array}$ & $\begin{array}{l}\text { Electricity generated from the } \\
\text { renewable energy resources such } \\
\text { as solar energy will beneficial for } \\
\text { reducing impacts from in-situ } \\
\text { leaching. }\end{array}$ \\
\hline $\begin{array}{l}\text { LCA of gold-silver-lead- } \\
\text { zinc-copper beneficiation } \\
\text { (Farjana et al., 2019b) }\end{array}$ & $\begin{array}{l}\text { Gold-silver beneficiation has highest } \\
\text { impact over the other metals }\end{array}$ & $\begin{array}{l}\text { Modification in the electricity grid } \\
\text { mix to enhance the energy } \\
\text { efficiency will be helpful to } \\
\text { reduce environmental burdens. }\end{array}$ \\
\hline $\begin{array}{ll}\text { LCA of } & \begin{array}{l}\text { gold-silver } \\
\text { operations }\end{array} \\
\text { refining } & \text { (Farjana et al., } 2019 \mathrm{~d} \text { ) }\end{array}$ & $\begin{array}{l}\text { Gold refining from the gold-silver } \\
\text { couple production have notable } \\
\text { environmental impact over the } \\
\text { combined production. }\end{array}$ & $\begin{array}{l}\text { Altering the material alloying } \\
\text { properties for stainless steel } \\
\text { would be beneficial to reduce } \\
\text { environmental impacts. }\end{array}$ \\
\hline
\end{tabular}

\subsection{LCA in iron mining}

Iron is one of the most abundant elements found in the earth's crust and is mostly widely used metal in modern civilization. The major miners and producers of iron are China, Australia, Brazil, Russia, and India. Iron can be mined from open pit mining or underground mining. Iron ore is extraction through drilling, blasting, excavating, loading, haulage, ore dumping, crushing, and screening. After screening lumped ores are sent through stacking, reclaiming, loading, transport. If the iron ores are fine ore then after screening it goes through stacking, reclaiming, loading, transport, pelleting and sintering. Table 8 describes the major findings and recommendations from the research conducted related to LCA of this metal.

Ferreira et al. analysed the iron production for an open pit mine located in Brazil. Dataset was collected from company reports. The functional unit considered was one tonne of iron ore concentration produced. 
The analysis was done using SimaPro software and IPCC method. They found that use of grinding media was the largest contributor to environmental emissions with the largest impact on human health and quality of ecosystems. Emission of inhalable inorganic materials is affecting human health. Greenhouse gas emissions are from electricity consumption which was $13.32 \mathrm{~kg} \mathrm{CO}_{2}$ eq for 1 ton of iron produced (Ferreira and Leite, 2015). Haque et al. analysed LCA of open pit iron ore mining and processing which comprises of drilling, blasting, loading, haulage, crushing, screening, separation, stacking, and stockpiling. The functional unit was 1 ton. The impact categories were gross energy requirements and GHG emissions. The analysis was done by Australian Indicator method. The analysis results showed that loading and haulage made the highest contribution to GHG (11.9 $\mathrm{CO}_{2}$ eq/t) (Haque and Norgate, 2015; Norgate and Haque, 2010). Gan et al. analysed LCA of mining and processing of iron ore mine in China. The iron mine considered consists of open pit mine and underground mine. The functional unit was 1 tonne of iron ore. The analysis was done using the IPCC method. They found that the highest GHG contribution is from agglomeration, loading, haulage, and ore processing, where mean value is $270 \mathrm{~kg} \mathrm{CO}_{2}$ eq tonne. The second largest contributor is vegetation(Gan and Griffin, 2018).

\section{Table 8}

Summary of the findings and recommendations for LCA of iron mining.

\begin{tabular}{|l|l|l|}
\hline Study reference & Key findings & Recommendation \\
\hline $\begin{array}{l}\text { LCA of iron mining in } \\
\text { Brazil (Ferreira and Leite, } \\
\text { 2015) }\end{array}$ & $\begin{array}{l}\text { The use of grinding media was the } \\
\text { largest contributor to environmental } \\
\text { emissions with the largest impact on } \\
\text { human health and quality of } \\
\text { ecosystems. }\end{array}$ & $\begin{array}{l}\text { Replacement of fossil fuels with } \\
\text { biodiesel would be beneficial for } \\
\text { reducing climate change effects. }\end{array}$ \\
\hline $\begin{array}{l}\text { LCA of iron mining in } \\
\text { Australia (Haque and } \\
\text { Norgate, 2015) }\end{array}$ & $\begin{array}{l}\text { The loading and haulage made the } \\
\text { highest contribution to GHG. }\end{array}$ & $\begin{array}{l}\text { Emerging technologies should be } \\
\text { adopted to reduce the } \\
\text { environmental burdens from } \\
\text { loading and hauling of iron ore. }\end{array}$ \\
\hline $\begin{array}{l}\text { LCA of iron mining in } \\
\text { China (Gan and Griffin, } \\
\text { 2018) }\end{array}$ & $\begin{array}{l}\text { The highest GHG contribution is from } \\
\text { agglomeration, loading, haulage, and } \\
\text { ore processing }\end{array}$ & $\begin{array}{l}\text { To reduce the environmental } \\
\text { impacts of iron mining in China, } \\
\text { high grade ore import from } \\
\text { abroad }\end{array}$ \\
\hline
\end{tabular}

\subsection{LCA in nickel mining}

Nickel is an important element for the military, marine, transport, aerospace, and architectural applications. In the nickel mining, the ore can be extracted from sulfidic ore or oxidic ore. If the ore is sulfidic, then it goes through beneficiation, pyrometallurgical extraction, refining. If the ore is oxidic, then it goes through ore preparation, hydrometallurgical extraction, and refining. Table 9 describes the major findings and recommendations from the research conducted related to LCA of this metal.

Khoo et al. studied three cradle-to-gate based nickel laterite technologies. The geographic region considered were Western Australia and Indonesia. The analysis was conducted using IMPACT 2002+ method, ReCiPe method, and Australian Indicator method. They were high-pressure acid leaching (HPAL), ferronickel, and direct nickel (DNi) process. Their study revealed that the highest environmental impact was from ferronickel, while the most sustainable was HPAL. It was also found that results obtained from Australian Indicator method were slightly higher than for other methods. Global warming potential was mostly contributed by fuel consumption in nickel reduction and smelting. Another major factor for GHG was coal consumption to produce steam (Khoo et al., 2017). Mistry et al. conducted LCA of nickel and ferronickel production. Their datasets were originated from nine companies, which comprised of $52 \%$ global nickel production and $40 \%$ global ferronickel production. The analysis was 
done using Gabi software and CML 2001 method. They showed that extraction and refining steps were the major contributor for PED and GWP (Mistry et al., 2016).

Table 9

Summary of the findings and recommendations for LCA of nickel mining.

\begin{tabular}{|l|l|l|}
\hline Study reference & Key findings & Recommendation \\
\hline $\begin{array}{l}\text { LCA of nickel mining for } \\
\text { Australia and Indonesia } \\
\text { (Khoo et al., 2017) }\end{array}$ & $\begin{array}{l}\text { The highest environmental impact was } \\
\text { from ferronickel, while the most } \\
\text { sustainable was HPAL due to fuel } \\
\text { consumption in nickel reduction and } \\
\text { smelting. }\end{array}$ & $\begin{array}{l}\text { Nickel production using the DNi } \\
\text { method would be beneficial over } \\
\text { the HPAL method to enhance } \\
\text { sustainability. }\end{array}$ \\
\hline $\begin{array}{l}\text { LCA of global nickel } \\
\text { production (Mistry et al., } \\
\text { 2016) }\end{array}$ & $\begin{array}{l}\text { The extraction and refining steps were } \\
\text { the major contributor for PED and } \\
\text { GWP. }\end{array}$ & $\begin{array}{l}\text { The nickel institute will update } \\
\text { their life cycle inventory datasets } \\
\text { based on technological } \\
\text { advancements, energy efficiency, } \\
\text { and raw material inputs. }\end{array}$ \\
\hline
\end{tabular}

\subsection{LCA in rare earth elements mining}

These group of metals contains fifteen types of elements, which can exist in the form of oxide minerals. These rare earth elements are used for making optical and electronics products. Different industrial sectors are using these rare earth elements metallurgy, oil, and agriculture. They are mined from China, Brazil, and the United States. Rare earth elements can be mined using open pit mining or underground mining. After mining, it goes through beneficiation stage, which involves crushing and grinding, magnetic separation, multi-stage flotation, filtering, washing, and conditioning. At the refining stage, the concentrated rare earth elements go through leaching, roasting, co-products separation, ion exchange, calcination, solvent extraction, mixed concentration, mischmetal refining, water leaching, multistage acid leaching, precipitation, and acid digestion. Table 10 describes the major findings and recommendations from the research conducted related to LCA of this metal.

Weng et al. conducted LCA of rare earth elements, based on cradle-to-gate 26 mining projects. Their focus was on GER (Gross Energy Requirements) and GWP. The analysis was done using SimaPro software, ReCiPe method, and CED method. The allocation method was an economy-based allocation of SimaPro. They found that the greatest environmental impacts were from ionic clay, monazite, bastnaesite where the impact is higher than for most common metals like bauxite, copper, and steel (Weng et al., 2016). Lima et al. analysed LCA of $4 \mathrm{~kg}$ of rare earth element with $2 \mathrm{~kg}$ of coproducts from a Brazilian ore. The analysis was done using the IMPACT 2002+ method where the datasets were from CETEM. Their study showed that largest consumption of hydrochloric acid and ammonium oxides produce radioactive emissions which impact on ozone depletion potential, and carcinogens thus impact on human health (Lima et al., 2018).

Table 10

Summary of the findings and recommendations for LCA of rare earth elements mining.

\begin{tabular}{|l|l|l|}
\hline Study reference & Key findings & Recommendation \\
\hline $\begin{array}{l}\text { LCA of rare earth } \\
\text { elements (Weng et al., } \\
\text { 2016) }\end{array}$ & $\begin{array}{l}\text { The greatest environmental impacts } \\
\text { were from ionic clay, monazite, } \\
\text { bastnaesite where the impact is higher } \\
\text { than for most common metals like } \\
\text { bauxite, copper, and steel. }\end{array}$ & $\begin{array}{l}\text { Rarechologies should adopt cleaner } \\
\text { ways based on mineralogy and } \\
\text { geological conditions. }\end{array}$ \\
\hline
\end{tabular}




\begin{tabular}{|c|c|c|}
\hline $\begin{array}{l}\text { LCA of rare earth } \\
\text { elements in Brazil (Lima } \\
\text { et al., 2018) }\end{array}$ & $\begin{array}{l}\text { The largest consumption of } \\
\text { hydrochloric acid and ammonium } \\
\text { oxides produce radioactive emissions } \\
\text { which impact on ozone depletion } \\
\text { potential, and carcinogens thus impact } \\
\text { on human health }\end{array}$ & $\begin{array}{l}\text { More investment is required in the } \\
\text { life cycle assessment sectors to } \\
\text { better justify the environmental } \\
\text { impact analysis. }\end{array}$ \\
\hline
\end{tabular}

\subsection{LCA in stainless steel production}

Steel industry is like oil and gas. Steel is widely used in construction works, transportation, packaging, and energy sector. China is one of the leading producers of steel. Steel is produced after processing in coke ovens, a sintering plant, blast furnace, and converter. Table 11 describes the major findings and recommendations from the research conducted related to LCA of this metal.

Norgate et al. conducted the LCA study of steel production where the functional unit was $1 \mathrm{~kg}$ of refined stainless steel. They assessed GWP, AP, and TED. The effects of different sources of electricity were also assessed. They used CSIRO software LCA-PRO for analysis. Their study revealed that when ferronickel was the nickel source, total energy consumption was higher than the case where nickel metal was used as a source. They also stated that nickel has the highest impact, then ferronickel, ferrochrome, and iron. While analysing the source of electricity, natural gas use could reduce the GWP without changing the total energy consumption, while hydroelectricity could reduce both (Norgate et al., 2007). Korol et al. assessed the cradle-to-grave LCA of steel production and arc furnace routes of Poland. They used SimaPro software and EcoInvent database for their analysis. The analysis method was IPCC, ReCipe, and CED. They showed that production of pig iron had the highest impact on GHG and fuel consumption due to electricity. They also showed that the iron ore sintering process was the highest contributor to dust and on GHG emissions. Direct GHG emissions were related to the combustion sources, while the indirect emissions were from fossils. The GHG value was $913 \mathrm{~kg} \mathrm{CO}_{2} \mathrm{eq} / \mathrm{FU}$ for natural electric arc furnace and $744 \mathrm{CO}_{2}$ eq/FU for crude steel (Burchart-Korol, 2013). Renzulli et al. studied cradle-to-gate LCA of an integrated steel mill in Italy. The system boundary was raw material extraction, the sintering operations, the coke production, and iron-steel production. The analysis method was ILCD while both mass and economy-based allocation were considered. Their results are similar like for Korol et al. that the most impactful processes were blast furnace and coke oven operations. More than $40 \%$ of the climate change, ozone depletion, and particulate matter were due to raw material transportation in the blast furnace and coke oven (Renzulli et al., 2016). Ma et al. analysed the crude steel production in China. Their functional unit was 1 ton of steel billet. The analysis method was IMPACT world+ model, IPCC, and ReCiPe. The system boundary includes mining, magnesium oxide production, transportation, and electricity generation. They analysed the water footprint caused by steel production and found that grey water footprint was higher than blue water footprint, while direct emissions played the key role for grey water footprint. Metal depletion was higher due to iron ore consumption (Ma et al., 2018).

Table 11

Summary of the findings and recommendations for LCA of steel mining.

\begin{tabular}{|l|l|l|}
\hline Study reference & Key findings & Recommendation \\
\hline LCA of steel (Norgate et & $\begin{array}{l}\text { Stated that when ferronickel was the } \\
\text { al., 2007) }\end{array}$ & $\begin{array}{l}\text { Alternative metal production } \\
\text { nickel source, total energy } \\
\text { technologies should be developed } \\
\text { consumption was higher than the case } \\
\text { where nickel metal was used as a } \\
\text { to reduce the environmental } \\
\text { burdens. } \\
\text { source. They also stated that nickel has } \\
\text { the highest impact, then ferronickel, }\end{array}$ \\
\hline
\end{tabular}


ferrochrome, and iron.

LCA of steel production The production of pig iron had the in Poland (Burchart- highest impact on GHG and fuel Korol, 2013)

LCA of steel mill in Italy (Renzulli et al., 2016) in China (Ma et al., 2018) process was the highest contributor to consumption due to electricity. They also showed that the iron ore sintering dust and on GHG emissions

The most impactful processes were blast furnace and coke oven operations. More than $40 \%$ of the climate change, ozone depletion, and particulate matter were due to raw material transportation in the blast furnace and coke oven

The water footprint caused by steel production and found that grey water footprint was higher than blue water footprint, while direct emissions played the key role for grey water footprint
In future, LCA of alternative steel production technologies should be conducted including thermodynamic analysis and exergy analysis.

Energy and fuel exchange between the power plants and factory can be modelled and analysed. LCA analysis can also be extended based on steel product rolling operations.

Further studies should be carried out based on dynamic database and spatial disparity in water footprint evaluation in different aspects.

\subsection{LCA in uranium mining}

Uranium is the source of nuclear power which is widely produced and naturally found. Nuclear power accounts for more than $10 \%$ of power production in the world. The uranium deposits are mostly found in Australia, Kazakhstan, and Canada. Uranium can be mined using open pit mining or underground mining. The mined ores are then going through crushing, grinding, leaching, solid separation, liquor extraction, uranium precipitation, solid separation, and drying. Table $\mathbf{1 2}$ describes the major findings and recommendations from the research conducted related to LCA of this metal.

Norgate et al. studied the LCA of nuclear power production for uranium while the ore grade was $0.15 \%$ $\mathrm{U}_{3} \mathrm{O}_{8}$. The functional unit was $1 \mathrm{MWh}$ of electricity produced from $1 \mathrm{GWe}$ nuclear reactor. The system boundary includes uranium ore mining to electricity production in a plant. Their study found that fuel enrichment stage made the highest contribution of GHG while the total GHG was $34 \mathrm{~kg} \mathrm{CO}$ eq/MWh. But if the ore grade falls to $0.01 \%$, then the GHG would be $60 \mathrm{~kg} \mathrm{CO} 2$ eq/MWh (Haque and Norgate, 2014; Norgate et al., 2014). Parker et al. studied the cradle-to-gate uranium mining and milling in Canada. They found that source of GHG, that is the energy used to produce electricity and process emissions from non-energy resources was the largest contributor to environmental emissions (Parker et al., 2016). Farjana et al. analysed and compared among open pit mining, underground mining, and in-situ leaching uranium mining operations. They found that in-situ leaching has a higher impact on all the environmental impact categories except ionising radiation. On the other hand, underground mining effects adversely on ionising radiation (S.H. Farjana et al., 2018a; Shahjadi Hisan Farjana et al., 2018b). Haque et al. conducted a comparative LCA study among in-situ leaching based production of copper, gold, and uranium. Their study was conducted based on Australian Impact method using SimaPro software. They showed that for uranium mining, well field related activities and chemical consumption contributed the most for GHG. Chemical consumption for leaching and mineral processing contributed about $20 \%$ of GHG, while wellfield related electricity consumption emits $74 \%$ of GHG (Haque and Norgate, 2014). 
Table 12

Summary of the findings and recommendations for LCA of uranium mining.

\begin{tabular}{|l|l|l|}
\hline Study reference & Key findings & Recommendation \\
\hline $\begin{array}{l}\text { LCA of nuclear power } \\
\text { production (Norgate et } \\
\text { al., 2014) }\end{array}$ & $\begin{array}{l}\text { The fuel enrichment stage made the } \\
\text { highest contribution of GHG }\end{array}$ & $\begin{array}{l}\text { New technologies in different } \\
\text { stages of nuclear fuel cycle would } \\
\text { be beneficial for reducing } \\
\text { environmental burdens. }\end{array}$ \\
\hline $\begin{array}{l}\text { LCA of uranium mining } \\
\text { in Canada (Parker et al., } \\
\text { 2016) }\end{array}$ & $\begin{array}{l}\text { The energy used to produce electricity } \\
\text { and process emissions from non- } \\
\text { energy resources was the largest } \\
\text { contributor to environmental emissions }\end{array}$ & $\begin{array}{l}\text { In future, detailed LCA study } \\
\text { impact categories should be } \\
\text { imnducted to reduce the } \\
\text { environmental burdens and to } \\
\text { trade off among the competing } \\
\text { energy products. }\end{array}$ \\
\hline $\begin{array}{l}\text { LCA of global uranium } \\
\text { mining (S.H. Farjana et } \\
\text { al., 2018a; Shahjadi } \\
\text { Hisan Farjana et al., } \\
\text { 2018b) }\end{array}$ & $\begin{array}{l}\text { The in-situ leaching has a higher } \\
\text { impact on all the environmental impact } \\
\text { categories except ionising radiation }\end{array}$ & $\begin{array}{l}\text { In future, further studies should be } \\
\text { conducted using the natural gas- } \\
\text { based scenario for process and } \\
\text { mine specific datasets. }\end{array}$ \\
\hline $\begin{array}{l}\text { LCA of uranium mining } \\
\text { in Australia (Haque and } \\
\text { Norgate, 2014) }\end{array}$ & $\begin{array}{l}\text { The well field related activities and } \\
\text { chemical consumption contributed the } \\
\text { most for GHG }\end{array}$ & $\begin{array}{l}\text { Electricity generated from the } \\
\text { renewable energy resources such } \\
\text { as solar energy will beneficial for } \\
\text { reducing impacts from in-situ } \\
\text { leaching. }\end{array}$ \\
\hline
\end{tabular}

\subsection{LCA in zinc mining}

Zinc is used for the galvanising process, to protect steel in the construction, transportation, and products. It is also used as an alloying element with copper. Zinc is produced from ore mining, mineral processing, concentration, roasting, leaching, purification, and electrolysis. Table 13 describes the major findings and recommendations from the research conducted related to LCA of this metal.

Genderen et al. analysed the cradle-to-gate LCA of zinc concentrate and special high-grade zinc. The geographical coverage considered in that study was global. The system boundary consists of zinc ore mining, concentration, transportation, and smelting. Datasets were collected from 24 mines and 18 smelters and analysed using Gabi software. The selected impact categories were GWP, AP, EU (Eutrophication), POCP, ODP, and PED. The analysis was done using the CML method, and the functional unit was 1 MT (Mega tonne) of zinc. Their study found that the impacts of zinc production were primarily due to energy consumption in the mining and concentration process. Electricity consumption was huge, which the country and grid mix played a significant role (Van Genderen et al., 2016). Qi et al. conducted LCA of hydrometallurgical zinc production in China which was based on National inventory datasets. The analysis was done by ReCiPe method, and the functional unit was 1 tonne of hydrometallurgical zinc production. Their study reveals that overall environmental emissions were due to zinc ore mining and energy consumption in the form of electricity and natural gas. They also stated that pollutants like copper, zinc, lead, which were emitted to the environment were responsible for human toxicity, marine aquatic ecotoxicity. Carbon-di-oxide emission from coal-based electricity generation was dominant for climate change and fossil depletion. Also, the heavy metals from iron ore mining and refining contributed to impacts on human health and water (Qi et al., 2017). Farjana et al. analyzed the gold-silver-lead-zinc-copper beneficiation process, which summarizes that gold-silver 
beneficiation has greatest impact over the other metal in these joint production which is due to the electricity usage through fossil fuel consumption (Farjana et al., 2019b).

Table 13

Summary of the findings and recommendations for LCA of zinc mining.

\begin{tabular}{|l|l|l|}
\hline Study reference & Key findings & Recommendation \\
\hline $\begin{array}{l}\text { LCA of global zinc } \\
\text { production } \\
\text { Genderen et al., 2016) } \\
\text { (Van }\end{array}$ & $\begin{array}{l}\text { The impacts of zinc production were } \\
\text { primarily due to energy consumption } \\
\text { in the mining and concentration } \\
\text { process. }\end{array}$ & $\begin{array}{l}\text { In future, including the unit } \\
\text { process details for LCA analysis } \\
\text { for concentration and smelting } \\
\text { would be beneficial for } \\
\text { sustainability. }\end{array}$ \\
\hline $\begin{array}{l}\text { LCA of zinc production } \\
\text { in China (Qi et al., 2017) }\end{array}$ & $\begin{array}{l}\text { The overall environmental emissions } \\
\text { were due to zinc ore mining and } \\
\text { energy consumption in the form of } \\
\text { electricity and natural gas. }\end{array}$ & $\begin{array}{l}\text { In future, their study would be } \\
\text { beneficial to build national LCI } \\
\text { database for zinc production in } \\
\text { China. }\end{array}$ \\
\hline $\begin{array}{l}\text { LCA of gold-silver-lead- } \\
\text { zinc-copper beneficiation } \\
\text { (Farjana et al., 2019b) }\end{array}$ & $\begin{array}{l}\text { Gold-silver beneficiation has highest } \\
\text { impact over the other metals }\end{array}$ & $\begin{array}{l}\text { Modification in the electricity grid } \\
\text { mix to enhance the energy } \\
\text { efficiency will be helpful to } \\
\text { reduce environmental burdens. }\end{array}$ \\
\hline
\end{tabular}

\subsection{Other metals and their LCA studies}

Table 14 describes the major findings and recommendations from the research conducted related to LCA of these metals.

Cobalt is a valuable metal found in the earth's crust which is widely used in the industrial applications. Cobalt mining has notable impact on human health due to cancer-causing elements which may cause heart disease, vision problem, etc. Farjana et al. conducted the life cycle assessment of cobalt extraction process. According to their study, cobalt extraction is harmful for eutrophication and global warming. Cobalt extraction requires large amount of electricity which is detrimental for global warming, and also is the blasting.

Cemented carbide has higher hardness and higher corrosion resistance, mostly used for drilling tools and cutting tools. China is the leading producer of cemented carbide. The cemented carbide ore is mined from extraction, crushing, milling, gravity method grinding, sulphide flotation, and roasting. In the hydrometallurgy stage, the cemented carbide ore is digested, filtrated, precipitated, extracted using solvent, and finally crystalised. In the pyrometallurgy stage, the ore goes through calcination, hydrogen reduction, and carburization. In the powder metallurgy stage, the ore goes through powder milling, granulation, and sintering. Furberg et al. conducted a cradle to gate LCA of cemented carbide production with cobalt, while the geographic location was non-Chinese (Canada and USA). Their study stated that impacts were due to elements like kerosene, tailings, water, and electricity. The highest impacts were on the category of TAP (terrestrial acidification), ODP (ozone depletion), FEU (freshwater eutrophication). And the lowest impact was on CC (climate change), PCOF (photochemical oxidant formation), and WD (water depletion) (Furberg et al., 2019).

Manganese is an essential element for batteries, fertilisers, and chemicals. Manganese is a widely used alloying element comes in conjunction to make ferroalloys. The manganese alloy is produced using mineral extraction, hauling, ore preparation and beneficiation, sintering and transportation, smelting, 
crushing, screening, and refining. Westfall et al. conducted an LCA study based on manganese alloys, where datasets were collected from 16 ore and alloy producers. The authors have conducted a cradle-togate LCA of silicomanganese, ferromanganese, and refined ferromanganese. The impact categories considered were GWP, AP, POCP, water, and waste. The analysis was done using CML 2001 method. According to their analysis, electricity demand, fuel consumption during smelting were the primary contributors for impact (Westfall et al., 2016).

Magnesium oxide cement are widely produced in China, North Korea, Turkey, Russia, and Australia. The magnesium oxide is produced from the raw material acquisition, crushing, vertical shaft kiln, precipitation tank, screening, crushing, grinding, and packaging. Ruan et al. analysed the LCA of magnesium oxide where the functional unit was 1 tonne. They showed that $\mathrm{MgO}$ has a lower impact on ecosystem and resources but larger impact on human health. The analysis was done using EcoIndicator 99 method. They considered five different case scenarios based on fossil fuel and raw material consumption (Ruan and Unluer, 2016).

Silver metal is most widely used for industrial purposes or for making jewelries. There are very few studies which addressed the environmental impact of silver mining processes. Farjana et al. analysed the environmental burdens associated with gold-silver-lead-zinc-copper beneficiation process (Farjana et al., 2019b). In another study, they analysed the environmental impacts of gold-silver refining operations (Farjana et al., 2019d). They found that silver beneficiation and refining have least environmental impacts than gold mining processes as they consume least amount of electricity, however, there are some impacts in the eutrophication, global warming, and ecotoxicity (Farjana et al., 2019b, 2019d).

Titanium oxides are widely used for making high-performance metal parts, artificial body parts, and engine elements. Ilmenite and rutile are the generally found form of titanium oxides. Ilmenite and rutile are extracted from mine site using heavy mineral concentration, rare earth drum separation, electrostatic separation circuit, and gravity separation circuit. Farjana et al. conducted a comparative LCA analysis of cradle-to-gate titanium oxides production. Ilmenite and rutile were considered where the geographic region considered was for Australia. The datasets were collected from AusLCI database and SimaPro software. The study revealed that rutile had a significant environmental impact than for ilmenite due to higher energy consumption and electricity use. The GHG was $0.295 \mathrm{~kg} \mathrm{CO}_{2} \mathrm{eq} / \mathrm{kg}$ of ilmenite production and $1.535 \mathrm{~kg} \mathrm{CO}_{2}$ eq/kg of rutile production (Shahjadi Hisan Farjana et al., 2018a).Table 14

Summary of the findings and recommendations for LCA of different metals

\begin{tabular}{|l|l|l|}
\hline Study reference & Key findings & Recommendation \\
\hline $\begin{array}{l}\text { LCA of cobalt extraction } \\
\text { process (Farjana et al., } \\
\text { 2019c) }\end{array}$ & $\begin{array}{l}\text { Eutrophication and global warming } \\
\text { impacts are higher due to electricity } \\
\text { consumption }\end{array}$ & $\begin{array}{l}\text { Altering the electricity generation } \\
\text { resources within the same grid } \\
\text { mix network will be beneficial for } \\
\text { sustainability. }\end{array}$ \\
\hline $\begin{array}{l}\text { LCA of non-Chinese } \\
\text { cemented carbide } \\
\text { production (Furberg et } \\
\text { al., 2019) }\end{array}$ & $\begin{array}{l}\text { The impacts were due to elements like } \\
\text { kerosene, tailings, water, and } \\
\text { electricity. }\end{array}$ & $\begin{array}{l}\text { In future, improvement in LCI } \\
\text { datasets is required to get rid of } \\
\text { uncertainty in environmental } \\
\text { sustainability. }\end{array}$ \\
\hline $\begin{array}{l}\text { LCA global } \\
\text { manganese production } \\
\text { (Westfall et al., 2016) }\end{array}$ & $\begin{array}{l}\text { The electricity demand, fuel } \\
\text { consumption during smelting were the } \\
\text { primary contributors for impact. }\end{array}$ & $\begin{array}{l}\text { In future, the LCI datasets and } \\
\text { LCA results can be integrated to }\end{array}$ \\
\hline $\begin{array}{l}\text { LCA of magnesium oxide } \\
\text { production (Ruan and } \\
\text { Unluer, 2016) }\end{array}$ & $\begin{array}{l}\text { MgO has a lower impact on ecosystem } \\
\text { and resources but larger impact on } \\
\text { human health }\end{array}$ & $\begin{array}{l}\text { An extensive database with } \\
\text { detailed LCI should be built to } \\
\text { conduct detailed LCA analysis. } \\
\text { Moreover, reduction of carbon } \\
\text { dioxide emissions should be }\end{array}$ \\
\hline
\end{tabular}




\begin{tabular}{|l|l|l|}
\hline & LCA of titanium oxides \\
in Australia (Shahjadi & $\begin{array}{l}\text { Rutile had a significant environmental } \\
\text { impact than for ilmenite due to higher } \\
\text { energy consumption and electricity } \\
\text { use. }\end{array}$ & $\begin{array}{l}\text { Electricity grid mix have } \\
\text { significant impact on the } \\
\text { environmental impact analysis } \\
\text { results which would be analysed } \\
\text { extensively in future. }\end{array}$ \\
\hline $\begin{array}{l}\text { LCA of gold-silver-lead- } \\
\text { zinc-copper beneficiation } \\
\text { (Farjana et al., 2019b) }\end{array}$ & $\begin{array}{l}\text { Gold-silver beneficiation has highest } \\
\text { impact over the other metals }\end{array}$ & $\begin{array}{l}\text { Modification in the electricity grid } \\
\text { mix to enhance the energy } \\
\text { efficiency will be helpful to } \\
\text { reduce environmental burdens. }\end{array}$ \\
\hline $\begin{array}{l}\text { LCA of gold-silver } \\
\text { refining } \\
\text { (Farjana et al., 2019d) }\end{array}$ & $\begin{array}{l}\text { Gold-silver refining from the couple } \\
\text { production of gold-silver have more } \\
\text { environmental burdens associated with } \\
\text { gold-silver-lead-zinc-copper couple } \\
\text { production. }\end{array}$ & $\begin{array}{l}\text { Altering the stainless steel } \\
\text { alloying properties would be } \\
\text { beneficial for sustainability. }\end{array}$ \\
\hline
\end{tabular}

\section{Discussion}

This chapter discusses the key aspects of the research articles on life cycle assessment of metal and mining industries. Analysis results can be discussed based on a combination of three different perspectives - mining technologies, environmental impacts, and energy consumption and integration. According to the discussion on the LCA results presented in table 15, which describes the key findings of these research papers on LCA based on metal type, it is quite evident that the common reason for largest environmental impact from mining is due to energy generation, fossil fuel consumption for energy and process heat generation. For aluminium, smelting and refining stage made the greatest contribution due to energy consumption and direct emissions to the environment. From the cemented carbide production, the mining, hydrometallurgy, and powder metallurgy stages made the greatest contribution due to kerosene use, sulfidic tailing, water, and electricity. In the case of coal mining, still electricity use, fossil fuel use for heat generation creates greater environmental impacts generated from the mining stage. Among the copper mining steps, solvent extraction and electrowinning in hydrometallurgy causes greater environmental impact rather than for pyrometallurgy, due to electricity, fossil fuel use for heat generation, and steel use. Gold mining is impactful in mining and comminution stage, due to well field related activities. Agglomeration, loading, haulage, and ore processing in iron mining is harmful to the environment due to the emission of inorganic chemical materials, use of electricity, and use of grinding media. From magnesium oxide production, calcination stage is highly impactful towards environment due to fossil fuel usage in the form of coal. For nickel production, primary extraction, nickel reduction, and smelting are impactful due to electricity usage and coal consumption to produce steam. The oxide separation stage in rare earth mining step, consume a huge amount of hydrochloric acid and ammonium oxides which is harmful. Pig iron in a blast furnace and iron ore sintering process in steel and stainlesssteel production causes greater impact due to electricity and fossil fuel usage. The fuel enrichment stage, well-field related stages, and the mining stage cause the greatest environmental impact of uranium mining due to electricity usage, use of chemicals and indirect emissions. In summary, mining and extraction stages made the greatest contribution in cemented carbide, coal, gold, titanium oxides, and zinc production. Smelting and refining steps cause a higher impact for aluminium, ferroalloy, nickel, and manganese mining which are due to significant amount of electricity consumed in smelting operation.

From the discussion presented above and in table 15, it is quite evident that most of the environmental emissions from mining industries are due to electricity consumption and fossil fuel usage, whatever the process is. Fossil fuel can be of the form of diesel oil, natural gas, heavy fuel oil, and residual fuel oi. These fossil fuels can be used for electricity production, process heat generation, and mechanical energy 
generation. Among these, fossil fuel use can be reduced or replaced by integrating renewable energy resources. Renewable energy can be used as an alternative fuel to generate electricity or to produce process heat. Several LCA studies assessed the environmental impact scenario with the integration of renewable energy resources in mining industries. There could be replacement by different types of renewables either partially or completely. Another major reason is the electricity grid mix, which varies from one country to another. The grid mix is a combination of fuel sources used to generate electricity. Among the three major components in LCA, electricity mix, technology mix, and heat mix- electricity mix and heat mix both are related to fossil fuel. Between them, a most adverse effect is from electricity use which impacts on GWP and AP. It also affects PED and GER. Replacing coal with natural gas may also be a solution to reduce GWP with same GER, but natural gas has more ionising radiation impact on human health. However, it is possible but dependent on the availability of the renewables at the mining site to integrate with the power generation system. This replacement is time-consuming and involves huge capital cost. Another important point is electricity generation efficiencies which could be improved after involving modern technologies.

Another major part is the integration of renewable resources to generate process heat in mining. Regarding solar energy, temperatures below $150^{\circ}$ Celsius could easily be achieved by non-CST (nonconcentrated solar thermal) technologies. Temperatures ranging between $150^{\circ}$ to $400^{\circ}$ Celsius is possible to generate with primary CST (concentrated solar thermal) technologies. There are few industries in the world where already process heat integration is operating with solar technologies. Few mines in Chile are utilising solar process heat for electrowinning operations. South Africa is using solar process heat for mining and cleaning operations. Cyprus, Austria, India, and Germany are also using solar process heat for different low-temperature mining operations which all operate below $100^{\circ}$ Celsius. The availability of solar energy also varies depending on the latitude and longitude, irradiation, and many other factors. Not all miner countries could have this renewable source of energy.

Other than energy integration, there are some technological factors which affect the environmental impacts of mining processes - the most important factor, which was discussed in almost every paper that ore grade effects largely on environmental burdens associated with mining. The deeper would the mining goes; the greater machinery requirements and the energy consumption would be. The more we are approaching towards development, more mining of the metals is required. Another important factor is the use of inorganic chemicals for chemical extraction, acid leaching, and electrowinning processes; which is more troublesome for environmental sustainability. Mining tailing management is another critical issue, which causes significant load on environment impacting human health, ecosystems, and resources.

\section{Table 15}

Key factors of environmental impacts from metal mining industries.

\begin{tabular}{|l|l|l|}
\hline Metal & $\begin{array}{l}\text { Highest } \\
\text { Impactful } \\
\text { Category }\end{array}$ & Impactful process \\
\hline $\begin{array}{l}\text { Aluminium (Nunez } \\
\text { and Jones, 2016; } \\
\begin{array}{l}\text { Paraskevas et al., } \\
\text { 2016; Tan and Khoo, } \\
\text { 2005) }\end{array}\end{array}$ & $\begin{array}{l}\text { GWP due to } \\
\text { smelting and } \\
\text { refining }\end{array}$ & $\begin{array}{l}\text { Smelting and refining, electricity consumption and direct } \\
\text { emissions. }\end{array}$ \\
\hline $\begin{array}{l}\text { Cobalt (Farjana et } \\
\text { al., 2019c) }\end{array}$ & GWP, EU & Extraction due to electricity consumption and blasting. \\
\hline $\begin{array}{l}\text { Cemented carbide } \\
\text { (Furberg et al., 2019) }\end{array}$ & TE, OD, FWE & $\begin{array}{l}\text { Mining, hydrometallurgy, and power metallurgy phases. } \\
\text { Due to kerosene, sulfidic tailing, water use, and electricity }\end{array}$ \\
\hline
\end{tabular}


use. Mining due to electricity usage, diesel oil consumption, fossil fuel, use of steel and heat.

Solvent extraction and electrowinning, leaching due to electricity usage, fossil fuel, sulfuric acid.

Smelting and refining due to electricity usage, fossil fuel.

Komnitsas, 2015; Haque and

Norgate, 2013)

Gold (Chen et al., GWP, MD

2018; Farjana et al., 2019b, 2019d; Haque and Norgate, 2014; Norgate and Haque, 2012)

Iron (Ferreira and Leite, 2015; Gan and Griffin, 2018; Haque and Norgate, 2015; Norgate and Haque, 2010)

Manganese (Westfall et al., 2016)

Magnesium oxide (Ruan and Unluer, 2016)

Nickel (Khoo et al. 2017; Mistry et al., 2016)

Rare earth element ODP, carcinogens (Lima et al., 2018; Zaimes et al., 2015)

Silver (Farjana et al., GWP, EU $\quad$ Stainless steel and electricity used in beneficiation and 2019b, 2019d)

Steel (Burchart- GHG, dust
refining processes.

Korol, 2013; Norgate et al., 2007; Renzulli et al., 2016)

\begin{tabular}{|c|c|c|}
\hline $\begin{array}{l}\text { Titanium } \\
\text { (Shahjadi }\end{array}$ & GHG & Mining due to electricity usage. \\
\hline $\begin{array}{l}\text { Uranium (Shahjadi } \\
\text { Hisan Farjana et al., }\end{array}$ & GHG & $\begin{array}{l}\text { Fuel enrichment, well field related activities, leaching due } \\
\text { to electricity usage, use of chemicals, and direct }\end{array}$ \\
\hline
\end{tabular}




\begin{tabular}{|l|l|l|}
$\begin{array}{l}\text { 2018b; Haque and } \\
\text { Norgate, 2014; } \\
\text { Norgate et al., 2014; } \\
\text { Parker et al., 2016) }\end{array}$ & & emissions. \\
\hline $\begin{array}{l}\text { Zinc (Qi et al., 2017; } \\
\text { Van Genderen et al., } \\
\text { 2016) }\end{array}$ & GWP & $\begin{array}{l}\text { Mining and concentration due to electricity consumption } \\
\text { and fossil fuel usage. }\end{array}$ \\
\hline
\end{tabular}

\section{Conclusion}

In conclusion, this review paper presents a comprehensive scenario of all the existing studies reported in the literature on the life cycle environmental impact analysis of metal mining industries. Sixteen metal mining industries are identified which have the significant research output that quantified the environmental effects based on LCA methods. A comprehensive compilation of the published work is being carried out, analysed, compared the impactful mining materials, processes which are energy intensive, thus harmful for global environmental sustainability. According to the findings presented in this paper, mining and extraction stages made the notable contribution in cemented carbide, coal, gold, titanium oxides, and zinc production. In addition, smelting and refining steps cause a considerable amount of impact for aluminium, ferroalloy, nickel, and manganese mining which are due to significant amount of electricity consumed in smelting operation. This paper also summarises the key methods of life cycle assessment which were utilised for mining industries. Limitations of these studies and future recommendation to improve the environmental sustainability are also presented. The most important challenge is the replacement of energy generation resources by renewables, which could significantly reduce the gross energy requirements and global warming potential, to achieve the sustainability goals for 2050.

In summary, there are some limitations, and future recommendations focused on LCA techniques and methods as follows:

a. Development of global LCA method which would be applicable irrespective of the geographic region of the mining company.

b. Development of aggregated allocation technique for coproduction of metals, which would be free from technological and economic differences of metals.

c. Analysis of complete LCA for each metal industries, as most of them, lack full LCA study, due to the research focus and availability of dataset.

d. Development of specific database focused on mining industries life cycle inventory datasets, which should contain inventory datasets for every type of mining technology per metal.

According to the analysis results presented in this study, it is evident that the mining industry is considerably affecting global warming potential and human health (carcinogenic and non-carcinogenic). The following measures could be adopted for significant reduction in the emission during the mining processes:

a. Replacement of electricity generation sources by renewables is of paramount importance. The choice of renewable energy resource would be dependent on the geographic location of the mine, availability of energy resources, and the capital cost of replacement.

b. Process heat generation sources could be altered by renewables. Mining processes should be classified as in terms of heating needs as low-temperature, medium temperature, and hightemperature process heat applications. Following that, the feasibility of process heat integration should be assessed approaching towards the practical integration. 
c. Sourcing high grade mining ore would be beneficial for the environment, which will consume less energy in the form of electricity and heat and less equipment to extract mined ore.

d. Decreasing the use of inorganic chemicals for leaching or increasing the efficiency of leaching processes would be beneficial to reduce the human health impacts, both carcinogenic and noncarcinogenic.

\section{Nomenclature}

\begin{tabular}{|c|c|}
\hline Term & Description \\
\hline AP & Acidification \\
\hline $\mathrm{CC}$ & Climate change \\
\hline CED & Cumulative energy demand \\
\hline CETEM & Center for mineral technology database \\
\hline CSIRO & Commonwealth Scientific and Industrial Research Organization \\
\hline CML & Center for methodological development \\
\hline CST & Concentrated solar thermal technology \\
\hline $\mathrm{DNi}$ & Direct Nickel method \\
\hline EDIP & Environmental Design of Industrial Products \\
\hline EU & Eutrophication \\
\hline FEU & Freshwater eutrophication \\
\hline FFD & Fossil fuel depletion \\
\hline FWE & Freshwater ecotoxicity \\
\hline GER & Gross energy requirements \\
\hline GWP & Global warming potential \\
\hline $\mathrm{HH}$ & Human health \\
\hline HPAL & High pressure acid leaching \\
\hline HT & Human toxicity \\
\hline IAI & International Aluminum Institute \\
\hline IPCC & Intergovernmental Panel on Climate Change \\
\hline ILCD & International Reference Life Cycle Data System \\
\hline ISO & International Organization for Standardization \\
\hline LCA & Life cycle assessment \\
\hline LCA-Pro & Life cycle assessment software name \\
\hline LCI & Life cycle inventory \\
\hline $\mathrm{ME}$ & Marine eutrophication \\
\hline MT & Mega tonne \\
\hline Non-CST & Non- concentrated solar thermal technology \\
\hline ODP & Ozone depletion potential \\
\hline POCP & photo-oxidant creation potential \\
\hline PMF & Particulate matter formation \\
\hline TAP & Terrestrial acidification \\
\hline USGS & U.S. Geological Survey database \\
\hline WD & Water resource depletion \\
\hline WMO & World Meteorological Organization \\
\hline WSP & Water scarcity potential \\
\hline $\mathrm{kg} \mathrm{CO} \mathrm{Cq}_{2}$ & Carbon dioxide equivalent \\
\hline
\end{tabular}




\section{References}

(JRC), I. for the E. and S. in the E.C.J.R.C., 2012. ILCD handbook, Http://Lct.Jrc.Ec.Europa.Eu/Assessment/Assessment/Projects. https://doi.org/10.278/33030

Acero, A.A.P., Rodríguez, C., Ciroth, A., 2015. LCIA methods Impact assessment methods in Life Cycle Assessment and their impact categories 1-22.

Adiansyah, J.S., Haque, N., Rosano, M., Biswas, W., 2017. Application of a life cycle assessment to compare environmental performance in coal mine tailings management. J. Environ. Manage. 199, 181-191. https://doi.org/10.1016/j.jenvman.2017.05.050

Althaus, H., Chudacoff, M., Hischier, R., Jungbluth, N., Osses, M., Primas, A., Hellweg, S., 2007. Life cycle inventories of chemicals. Ecoinvent data v2.0, Swiss Centre for Life Cycle Inventories. 1-957.

Althaus, H.J., Classen, M., 2005. Life cycle inventories of metals and methodological aspects of inventorying material resources in ecoinvent. Int. J. Life Cycle Assess. 10, 43-49. https://doi.org/10.1065/lca2004.11.181.5

Bartzas, G., Komnitsas, K., 2015. Life cycle assessment of ferronickel production in Greece. Resour. Conserv. Recycl. 105, 113-122. https://doi.org/10.1016/j.resconrec.2015.10.016

Burchart-Korol, D., 2013. Life cycle assessment of steel production in Poland: A case study. J. Clean. Prod. 54, 235-243. https://doi.org/10.1016/j.jclepro.2013.04.031

Burchart-Korol, D., Fugiel, A., Czaplicka-Kolarz, K., Turek, M., 2016. Model of environmental life cycle assessment for coal mining operations. Sci. Total Environ. 562, 61-72. https://doi.org/10.1016/j.scitotenv.2016.03.202

Chen, W., Geng, Y., Hong, J., Dong, H., Cui, X., Sun, M., Zhang, Q., 2018. Life cycle assessment of gold production in China. J. Clean. Prod. 179, 143-150. https://doi.org/10.1016/j.jclepro.2018.01.114

Cortez-Lugo, M., Riojas-Rodríguez, H., Moreno-Macías, H., Montes, S., Rodríguez-Agudelo, Y., Hernández-Bonilla, D., Catalán-Vázquez, M., Díaz-Godoy, R., Rodríguez-Dozal, S., 2018. Evaluation of the effect of an environmental management program on exposure to manganese in a mining zone in Mexico. Neurotoxicology 64, 142-151. https://doi.org/10.1016/j.neuro.2017.08.014

Curran, M.A., 2012. Life Cycle Assessment Handbook. https://doi.org/10.1002/9781118528372

DEE, 2017. Australian Energy Update. Aust. Gov. 2016, 27. https://doi.org/2203-8337

Ekman Nilsson, A., Macias Aragonés, M., Arroyo Torralvo, F., Dunon, V., Angel, H., Komnitsas, K., Willquist, K., 2017. A Review of the Carbon Footprint of $\mathrm{Cu}$ and $\mathrm{Zn}$ Production from Primary and Secondary Sources. Minerals 7, 168. https://doi.org/10.3390/min7090168

EPA, 2018. The Emissions \& Generation Resource Integrated Database (eGRID) Technical Support Document. US Environ. Prot. Agency 106.

European Commission -- Joint Research Centre -- Institute for Environment and Sustainability, 2010. International Reference Life Cycle Data System (ILCD) Handbook -- General guide for Life Cycle Assessment -- Detailed guidance, Constraints. https://doi.org/10.2788/38479

Farjana, S.H., Huda, N., Mahmud, M.A.P., 2019a. Impacts of aluminum production: A cradle to gate investigation using life-cycle assessment. Sci. Total Environ. 663, 958-970. https://doi.org/10.1016/j.scitotenv.2019.01.400

Farjana, S.H., Huda, N., Mahmud, M.A.P., 2019b. Life cycle analysis of copper-gold-lead-silver-zinc beneficiation process. Sci. Total Environ. 659, 41-52. https://doi.org/10.1016/j.scitotenv.2018.12.318

Farjana, S.H., Huda, N., Mahmud, M.A.P., 2019c. Life cycle assessment of cobalt extraction process. J. Sustain. Min. https://doi.org/10.1016/j.jsm.2019.03.002

Farjana, S.H., Huda, N., Mahmud, M.A.P., 2018a. Life-Cycle environmental impact assessment of mineral industries, in: IOP Conference Series: Materials Science and Engineering. https://doi.org/10.1088/1757-899X/351/1/012016

Farjana, S.H., Huda, N., Mahmud, M.A.P., Lang, C., 2019d. Impact Analysis of Gold-Silver Refining Processes Through Life-Cycle Assessment. J. Clean. Prod. https://doi.org/10.1016/j.jclepro.2019.04.166 
Farjana, S.H., Huda, N., Mahmud, M.A.P., Lang, C., 2018a. Towards sustainable TiO 2 production : An investigation of environmental impacts of ilmenite and rutile processing routes in Australia. J. Clean. Prod. 196, 1016-1025. https://doi.org/10.1016/j.jclepro.2018.06.156

Farjana, S.H., Huda, N., Mahmud, M.A.P., Lang, C., 2018b. Comparative Life-cycle Assessment of Uranium Extraction Processes in Australia. J. Clean. Prod. 202, 666-683. https://doi.org/10.1016/j.jclepro.2018.08.105

Farjana, S.H., Huda, N., Parvez Mahmud, M.A., 2018b. Environmental impact assessment of european non-ferro mining industries through life-cycle assessment, in: IOP Conference Series: Earth and Environmental Science. https://doi.org/. IOP Conference Series: Earth and Environmental Science, 154, [012019]. DOI: 10.1088/1755-1315/154/1/012019

Ferreira, H., Leite, M.G.P., 2015. A Life Cycle Assessment study of iron ore mining. J. Clean. Prod. 108, 1081-1091. https://doi.org/10.1016/j.jclepro.2015.05.140

Fogler, S., Timmons, D., 1998. An Overview of the ISO 14040 Life Cycle Assessment Approach and an Industrial Case Study. Argentum V.

Fugiel, A., Burchart-Korol, D., Czaplicka-Kolarz, K., Smoliński, A., 2017. Environmental impact and damage categories caused by air pollution emissions from mining and quarrying sectors of European countries. J. Clean. Prod. 143, 159-168. https://doi.org/10.1016/j.jclepro.2016.12.136

Furberg, A., Arvidsson, R., Molander, S., 2019. Environmental life cycle assessment of cemented carbide (WC-Co) production. J. Clean. Prod. 209, 1126-1138. https://doi.org/10.1016/j.jclepro.2018.10.272

Gan, Y., Griffin, W.M., 2018. Analysis of life-cycle GHG emissions for iron ore mining and processing in China-Uncertainty and trends. Resour. Policy 58, 90-96. https://doi.org/10.1016/j.resourpol.2018.03.015

Goedkoop, M., Oele, M., Vieira, M., Leijting, J., Ponsioen, T., Meijer, E., 2014. SimaPro Tutorial 89. https://doi.org/10.1142/S0218625X03005293

Gorman, M.R., Dzombak, D.A., 2018. A review of sustainable mining and resource management: Transitioning from the life cycle of the mine to the life cycle of the mineral. Resour. Conserv. Recycl. 137, 281-291. https://doi.org/10.1016/j.resconrec.2018.06.001

Grande, C.A., Blom, R., Spjelkavik, A., Moreau, V., Payet, J., 2017. Life-cycle assessment as a tool for eco-design of metal-organic frameworks (MOFs). Sustain. Mater. Technol. 14, 11-18. https://doi.org/10.1016/j.susmat.2017.10.002

Guimarães da Silva, M., Costa Muniz, A.R., Hoffmann, R., Luz Lisbôa, A.C., 2018. Impact of greenhouse gases on surface coal mining in Brazil. J. Clean. Prod. 193, 206-216. https://doi.org/10.1016/j.jclepro.2018.05.076

Haque, N., Norgate, T., 2015. Life cycle assessment of iron ore mining and processing, Iron Ore: Mineralogy, Processing and Environmental Sustainability. Elsevier Ltd. https://doi.org/10.1016/B978-1-78242-156-6.00020-4

Haque, N., Norgate, T., 2014. The greenhouse gas footprint of in-situ leaching of uranium, gold and copper in Australia. J. Clean. Prod. 84, 382-390. https://doi.org/10.1016/j.jclepro.2013.09.033

Haque, N., Norgate, T., 2013. Estimation of greenhouse gas emissions from ferroalloy production using life cycle assessment with particular reference to Australia. J. Clean. Prod. 39, 220-230. https://doi.org/10.1016/j.jclepro.2012.08.010

Hischier, R., Weidema, B., Althaus, H.-J., Bauer, C., Doka, G., Dones, R., Frischknecht, R., Hellweg, S., Humbert, S., Jungbluth, N., Köllner, T., Loerincik, Y., Margni, M., Nemecek, T., 2010. Implementation of Life Cycle Impact Assessment Methods Data v2.2 (2010). ecoinvent Rep. No. 3 176.

International Institute for Environment and Development, 2002. Appendix 2 : Environmental and Social Impacts of Mining. Glob. Biodivers.

JRC European commission, 2011. ILCD Handbook: Recommendations for Life Cycle Impact Assessment in the European context, Vasa. https://doi.org/10.278/33030

Khoo, J.Z., Haque, N., Woodbridge, G., McDonald, R., Bhattacharya, S., 2017. A life cycle assessment of a new laterite processing technology. J. Clean. Prod. 142, 1765-1777. 
https://doi.org/10.1016/j.jclepro.2016.11.111

Li, C., Bai, H., Lu, Y., Bian, J., Dong, Y., Xu, H., 2018. Life-cycle assessment for coal-based methanol production in China. J. Clean. Prod. 188, 1004-1017. https://doi.org/10.1016/j.jclepro.2018.04.051

Lima, F.M., Lovon-Canchumani, G.A., Sampaio, M., Tarazona-Alvarado, L.M., 2018. Life Cycle Assessment of the Production of Rare Earth Oxides from a Brazilian Ore. Procedia CIRP 69, 481486. https://doi.org/10.1016/j.procir.2017.11.066

Lodhia, S., Martin, N., 2014. Corporate Sustainability Indicators: An Australian Mining Case Study. J. Clean. Prod. 84, 107-115. https://doi.org/10.1016/j.jclepro.2014.05.050

Long, K.R., DeYoung, J.H., Ludington, S.D., 1998. Database of significant deposits of gold, silver, copper, lead, and zinc in the United States. Part A: Database description and analysis. Open-File Report 98-206A. US Geol. Surv. 1-60.

Ma, X., Ye, L., Qi, C., Yang, D., Shen, X., Hong, J., 2018. Life cycle assessment and water footprint evaluation of crude steel production: A case study in China. J. Environ. Manage. 224, 10-18. https://doi.org/10.1016/j.jenvman.2018.07.027

Marguerite, R., Tim, G., Maartje, S., James, L., Brad, R., Fabiano, X., Jonas, B., Annette, C., Joe, J., 2015. Best Practice Guide for Life Cycle Impact Assessment ( LCIA ) in Australia ALCAS Impact Assessment Committee. ALCAS Impact Assess. Comm.

Memary, R., Giurco, D., Mudd, G., Mason, L., 2012. Life cycle assessment: A time-series analysis of copper. J. Clean. Prod. 33, 97-108. https://doi.org/10.1016/j.jclepro.2012.04.025

Menoufi, K.A.I., 2011. Life Cycle Analysis and Life Cycle Impact Assessment methodologies: State of the art. Master Thesis $1-84$.

Mistry, M., Gediga, J., Boonzaier, S., 2016. Life cycle assessment of nickel products. Int. J. Life Cycle Assess. 21, 1559-1572. https://doi.org/10.1007/s11367-016-1085-X

Mudd, G.M., 2009. The Sustainability of Mining in Australia: Key Production Trends and Their Environmental Implications for the Future. https://doi.org/978-0-9803199-4-1

Mutchek, M., Cooney, G., Pickenpaugh, G., Marriott, J., Skone, T., 2016. Understanding the Contribution of Mining and Transportation to the Total Life Cycle Impacts of Coal Exported from the United States. Energies 9, 559. https://doi.org/10.3390/en9070559

Norgate, T., Haque, N., 2012. Using life cycle assessment to evaluate some environmental impacts of gold production. J. Clean. Prod. 29-30, 53-63. https://doi.org/10.1016/j.jclepro.2012.01.042

Norgate, T., Haque, N., 2010. Energy and greenhouse gas impacts of mining and mineral processing operations. J. Clean. Prod. 18, 266-274. https://doi.org/10.1016/j.jclepro.2009.09.020

Norgate, T., Haque, N., Koltun, P., 2014. The impact of uranium ore grade on the greenhouse gas footprint of nuclear power. J. Clean. Prod. 84, 360-367. https://doi.org/10.1016/j.jclepro.2013.11.034

Norgate, T.E., 2001. A Comparative Life Cycle Assessment of Copper Production Processes.

Norgate, T.E., Jahanshahi, S., Rankin, W.J., 2007. Assessing the environmental impact of metal production processes. J. Clean. Prod. 15, 838-848. https://doi.org/10.1016/j.jclepro.2006.06.018

Northey, S., Haque, N., Mudd, G., 2013. Using sustainability reporting to assess the environmental footprint of copper mining. J. Clean. Prod. 40, 118-128. https://doi.org/10.1016/j.jclepro.2012.09.027

Nunez, P., Jones, S., 2016. Cradle to gate: life cycle impact of primary aluminium production. Int. J. Life Cycle Assess. 21, 1594-1604. https://doi.org/10.1007/s11367-015-1003-7

Paraskevas, D., Kellens, K., Van De Voorde, A., Dewulf, W., Duflou, J.R., 2016. Environmental Impact Analysis of Primary Aluminium Production at Country Level. Procedia CIRP 40, 209-213. https://doi.org/10.1016/j.procir.2016.01.104

Parker, D.J., MNaughton, C.S., Sparks, G.A., 2016. Life Cycle Greenhouse Gas Emissions from Uranium Mining and Milling in Canada. Environ. Sci. Technol. 50, 9746-9753. https://doi.org/10.1021/acs.est.5b06072

PRé, 2018. SimaPro Database Manual Methods Library Colophon Title: SimaPro Database Manual Methods Library. https://doi.org/10.1017/CBO9781107415324.004 
Qi, C., Ye, L., Ma, X., Yang, D., Hong, J., 2017. Life cycle assessment of the hydrometallurgical zinc production chain in China. J. Clean. Prod. 156, 451-458. https://doi.org/10.1016/j.jclepro.2017.04.084

Ranängen, H., Lindman, A., 2017. A path towards sustainability for the Nordic mining industry. J. Clean. Prod. 151, 43-52. https://doi.org/10.1016/j.jclepro.2017.03.047

Raugei, M., Ulgiati, S., 2009. A novel approach to the problem of geographic allocation of environmental impact in Life Cycle Assessment and Material Flow Analysis. Ecol. Indic. 9, 1257-1264. https://doi.org/10.1016/j.ecolind.2009.04.001

Renzulli, P.A., Notarnicola, B., Tassielli, G., Arcese, G., Di Capua, R., 2016. Life cycle assessment of steel produced in an Italian integrated steel mill. Sustain. 8. https://doi.org/10.3390/su8080719

Ruan, S., Unluer, C., 2016. Comparative life cycle assessment of reactive $\mathrm{MgO}$ and Portland cement production. J. Clean. Prod. 137, 258-273. https://doi.org/10.1016/j.jclepro.2016.07.071

Santero, N., Hendry, J., 2016. Harmonization of LCA methodologies for the metal and mining industry. Int. J. Life Cycle Assess. 21, 1543-1553. https://doi.org/10.1007/s11367-015-1022-4

Stewart, M., Petrie, J., 2006. A process systems approach to life cycle inventories for minerals: South African and Australian case studies. J. Clean. Prod. 14, 1042-1056. https://doi.org/10.1016/j.jclepro.2004.08.008

Tan, R.B.H., Khoo, H.H., 2005. An LCA study of a primary aluminum supply chain. J. Clean. Prod. 13, 607-618. https://doi.org/10.1016/j.jclepro.2003.12.022

Teh, S.H., Wiedmann, T., Castel, A., de Burgh, J., 2017. Hybrid life cycle assessment of greenhouse gas emissions from cement, concrete and geopolymer concrete in Australia. J. Clean. Prod. 152, 312320. https://doi.org/10.1016/j.jclepro.2017.03.122

Tost, M., Hitch, M., Chandurkar, V., Moser, P., Feiel, S., 2018. The state of environmental sustainability considerations in mining. J. Clean. Prod. 182, 969-977. https://doi.org/10.1016/j.jclepro.2018.02.051

Van Genderen, E., Wildnauer, M., Santero, N., Sidi, N., 2016. A global life cycle assessment for primary zinc production. Int. J. Life Cycle Assess. 21, 1580-1593. https://doi.org/10.1007/s11367-016-11318

Weidema, B.P., Bauer, C., Hischier, R., Mutel, C., Nemecek, T., Reinhard, J., Vadenbo, C.O., Wernet, G., 2013. Data quality guideline for the ecoinvent database version $33,169$.

Weidema, B.P., Norris, G. a, 2002. Avoiding co-product allocation in the metals sector. ICMM Int. Work. Life Cycle Assess. Met.

Weng, Z., Haque, N., Mudd, G.M., Jowitt, S.M., 2016. Assessing the energy requirements and global warming potential of the production of rare earth elements. J. Clean. Prod. 139, 1282-1297. https://doi.org/10.1016/j.jclepro.2016.08.132

Westfall, L.A., Davourie, J., Ali, M., McGough, D., 2016. Cradle-to-gate life cycle assessment of global manganese alloy production. Int. J. Life Cycle Assess. 21, 1573-1579. https://doi.org/10.1007/s11367-015-0995-3

Wolf, M.A., Pant, R., Chomkhamsri, K., Sala, S., Pennington, D., 2012. The International Reference Life Cycle Data System (ILCD) Handbook, European Commission. JRC references reports. https://doi.org/10.2788/85727

WORLD ECONOMIC FORUM, 2015. Mining \& Metals in a Sustainable World 2050 1-44. https://doi.org/REF 250815

Zaimes, G.G., Hubler, B.J., Wang, S., Khanna, V., 2015. Environmental Life Cycle Perspective on Rare Earth Oxide Production. ACS Sustain. Chem. Eng. 3, 237-244. https://doi.org/10.1021/sc500573b

Zhang, L., Wang, J., Feng, Y., 2018. Life cycle assessment of opencast coal mine production: a case study in Yimin mining area in China. Environ. Sci. Pollut. Res. 25, 8475-8486. https://doi.org/10.1007/s1 1356-017-1169-6 


\section{Highlights:}

1. A review based on life cycle assessment studies in mining and mineral processing

2. 16 metal mining industries are reviewed

3. Summarized key factors of environmental effects using LCA

4. Future research directions are highlighted 


\title{
A Review on Impact of Mining and Mineral Processing Industries through Life Cycle Assessment
}

\author{
Shahjadi Hisan Farjana ${ }^{a}$, Nazmul Huda ${ }^{a, n}$, M. A. Parvez Mahmud ${ }^{a}$, R. Saidur ${ }^{\text {b,c }}$ \\ ${ }^{a}$ School of Engineering, Macquarie University, Sydney, NSW-2109, Australia \\ ${ }^{\mathrm{n}}$ Corresponding Author: Email: nazmul.huda@mq.edu.au, Phone: +61 0298502249 \\ ${ }^{\mathrm{b}}$ Research Centre for Nano-Materials and Energy Technology (RCNMET), School of Science and Technology, Sunway \\ University, No. 5, Jalan Universiti, Bandar Sunway, Petaling Jaya, 47500 Selangor Darul Ehsan, Malaysia \\ ${ }^{\mathrm{c}}$ Department of Engineering, Lancaster University, LA1 4YW,UK
}

\begin{abstract}
:
This review paper analysed and summarised the significant research outputs published on the environmental impact assessment of mining and mineral processing industries through life cycle assessment. The paper presents valuable insights in identifying the gaps, This paper will also identify the gaps, where should the focus be in the mining and mineral processing industries for a sustainable future. Mining and mineral processing industries has been the key focus of research in many countries are in the focus of scientific society due to its increasing sustainability concerns that affects about global warming and climate change. Mining processes u $u s e$ of heavy equipment that consumes electrical energy, mechanical energy, and enormous amount of process heat is a key contributor of the overall impacts in the industry. Due to the use of heavy equipment and eorrespending associated energy consumption, these industrial sector contribute notably peses a severe threat to global warming, human health, ecosystems, and resources. Assessment and quantification of the environmental effects caused by the mining industries due to energy consumption have been a key foeus of the seientific community for the last 25 years. Among the various environmental impact assessment tools which are widely used to identify sustainability indicators, life cycle assessment (LCA) is a well justified scientific tool approach among the practitioners and researchers. Though state of the art technological tools and resources are being used now a days, there is still a research gap in identifying the key mining processes which need to be the focus of attention. Renewable energy integration in the mineral processing sector and process heating from green energy sources is becoming the emergent field of research. The review results reveal, the assessment indicators in human health and ecosystems are key factors that are mostly missing in the previous studies which are crucial for people or community living nearby mining area. This review paper will-identifies $y$ the research gaps to the existing literature that can form the base for future provide-research direction in the future research-field of LCA-research and sustainable energy integration in mining and mineral processing industries.
\end{abstract}

Keywords: Mining, mineral processing, industries, life cycle assessment, environmental impact, energy integration, renewable energy, sustainability.

\section{Introduction}

Mining and mineral processing metal-industries contribute a gigantic share in a nation's economy in addition to supplying the invaluable resources for modern civilization. are important not only for industrial consumers but also for governments, stakeholders.-Most importantly, this sector plays a crucial role in sustainable economic development and overall GDP growth. - To keep pace with the growing demand of the sustainable world, World Economic Forum is orking-aiming to make the mining world sustainable by 2050 . There are a few goals which should be achieved, and several industrial mining governing bodies are working to settle those goals. These are drivers of change, transitional areas, resource scenario in future, and action plans. The drivers of change can be classified into five types: 
environmental, technological, societal, geopolitical, and geographic for the growing need in the environmental effect's management in the field of climate change, biodiversity, and water. World economic forum also outlined the key mining and mineral sectors which are crucial for setting the sustainable development goal by 2050: aluminium, iron, nickel, copper, and zinc mining (Ranängen and Lindman, 2017; WORLD ECONOMIC FORUM, 2015). In line with the economic demand and growth, the environmental effects and its consequences are also increasing exponentially. Sustainable development meant to an accord between economic activity and environmental concerns. The goal of sustainable development in mining industries is to increase metal production in such a way that it should ascertain the cost and efficiency, without significantly reducing the potential for future generation. The first step to To-achieve this goal_, it is the duty of the scientific society impacts caused by the mining industries for current practices in present scenario-and identify the ways to reduce the environmental effects without compromising the thus maximising the production. According to International Council on Mining and Metals there are ten principals, of which two are directly related to climate change, water, and biodiversity_-_the_-considerations of environmental side of sustainable development. According to principle number six, continuous improvement should be pursued in environmental issues like water, climate change, and energy use (Gorman and Dzombak, 2018; Mudd, 2009; Tost et al., 2018).

RegardingOn the subject of the environmental impacts of mining and mineral processing, it can be generally classified as waste management, acid mine drainage, sedimentation, metals deposition, and biodiversity. The Mining processes produce too much-considerable amount of waste outputs, which depends on the is determined by the type of mineral to be mined and type of ore deposit. It is very challenging to dispose of such a large huge-amount of wastes from mining and mineral processing which is detrimental for aquatic environment and ecosystems. Water pollution from mining wastes causes acid mine drainage, sedimentation, and deposition of metals. Erosion through waste rock piles and runoff after rainfall increases the sedimentation. Acid mine drainage is another type of serious environmental impacts from mining, which occurs from sulfidic minerals. Contamination of acidic water on surface and groundwater resources threatens the aquatic life and plants. Metals and reagents used for processing the significant amount of minerals are also gets released into the environments, gets mixed, and threatens the life of aquatics and plants. Removing the plants and vegetables from the ore mining area results in deforestation threatens the structure of the species, which is affecting the biodiversity (Cortez-Lugo et al., 2018; Fugiel et al., 2017; International Institute for Environment and Development, 2002).

Though the degree of these environmental impacts varies from one mine to another, from one metal to another metal, and correlates with the volume of production, the need for it is obvious to determining e and quantifying the effects caused by the sector mining industries is inevitable to identify the key processes/ materials which are responsibleaccountable for major environmental emissions and impacts. For example, the key processes are power plants used for electricity generation, diesel heat used for process heat generation, blasting process, or the ore mining (S.H. Farjana et al., 2018a, 2018b, Shahjadi Hisan Farjana et al., 2018a, 2018b). Among the various factors, fossil fuel consumption for electricity generation and process heat generation is the greatest contributor to environmental effects and emissions caused by the mining industries. The form of non-renewable fuels include coal, natural gas, diesel, heavy fuel oil, bitumen which are producing heat and electrical energy. After combustion, fossil fuel generates in-carbon di-oxides, nitrous oxides, sulphur di-oxides and produces fly ashes which are polluting the environment. Due to the increasing demand for global development, metal exploration is going into deeper of the surface, which also requires heavy equipment to extract lower grade ore minerals. These lower grade metal extractions also demand higher consumption of electricity for more equipment in use. However, increased environmental emission should be diversified in the fields of the environment- global warming, human health, ecosystems, and resources (Shahjadi Hisan Farjana et al., 2018b, 2018a; Farjana et al., 2019a). 
In the mineral processing industries, from in the last 15 years, there are around 40 significant research outputs that are published based on the life cycle assessment of specific metal mining processes or a system of processes. The life cycle assessment (LCA) results vary from one standardised LCA method to another, from one simulation software to another, and from one mining metal to another. Despite all the key factors, the respensibleliable processes crucial for environmental emission for each metal is fixed irrespective of the quantification of results. This statement is validated using the review presented in this paper. The main aim major purpose-of this review paper is to quantify and analyse the past research works-in LCA of minerals and mining processes to fill the knowledge gaps in major mining and mineral processes and materials accountable for environmental impacts from mining, environmental categories to be affected, quantity of emissions, and suggest alternatives to reduce the environmental impacts from the mining processes. Section 2 describes the materials and methods utilised in this review work. Section 3 describes the LCA methods used for life cycle assessment studies in mining and minerals industries. Section 4 comprehensively categorises and describes the LCA works of minerals and mining industries. Section 5 compares and summarises the major materials/processes responsible for environmental emissions from the mining industries, describes the research gaps and future scope till to date in the LCA research area in relation with mining and mineral processing industries. Finally, the paper finishes in Section 6 by providing some the-concluding remarks.

\section{Materials and Methods:}

As the first step of this systematic review, few steps are followed to accomplish this review. At first, the relevant and significant research outputs, and their published articles are sorted and classified as part of the material collection process. In total, Total-forty journal and conference papersarticles are exclusively selected which are focused on the LCA on mining industries. Among which most of the papers were published in Journal of Cleaner Production, International Journal of Life Cycle Assessment, Science of the Total Environment, Resources Conservation and Recycling, Journal of Environmental Management, and Journal of Sustainable Mining. These papers are classified based on the type of metal mining industry under consideration. Overall sixteen metals and theirmining processes were exclusivelyrigorously studied through life cycle assessment. Those are aluminium (3 papers), copper (5 papers), coal (4 papers), gold ( 3 papers), iron ( 37 papers), rare earth element (2 papers), stainless steel (4 papers), uranium (4 papers), zinc (3 papers), nickel (4 papers), cemented carbide ( 1 paper), ferroalloy ( 1 paper), manganese ( 1 paper), magnesium oxide (1 paper), and titanium oxides ( 1 paper).

In the next step, these publications are extensively studied to identify the key criteria's for conducting the extensive-comprehensive literature review. This step can be termed as a comprehensive analysis of the existing literature. In this stage, all the se-publications are studied irrespective of their evaluation methods, goal, and scope of their research. This stage also investigated the common trends and evaluation criteria followed by mining LCA specialists. Furthermore, LCA methods that were considered in those studies followed in these research works is are also classified, which is further-is described in Section 3 of this review paper. LCA methods are summarised as their impact assessment methods in practice, system boundary, impact categories in use, general material inputs and outputs, databases, and their functional units.

In the following step, the evaluation categories are selected, and the papers, their methods, and results are sorted based on the evaluation categories. The evaluation-criteria are which were-selected are-based on the metals, their general properties, mining processes, system boundary, geographic location, selected environmental impact categories to be assessed, most impactful mining process identification, and key emission materials.

In the last step, materials and their evaluated criteria are scientifically evaluated, presented, and identified the research gaps in these previous research studiesworks. The papers are further studied to find out the 
research gap on metals which got comparatively lesser attention were never under the foeus of from LCA practitionersspecialists, mining processes which lacks attention, key materials used in mining which are harmful to the environment and suggesting possible solutions to reduce the notable amount of emissions from the mining process or industries.

Figure 1 describes the key steps of the methods utilised to perform this review study.

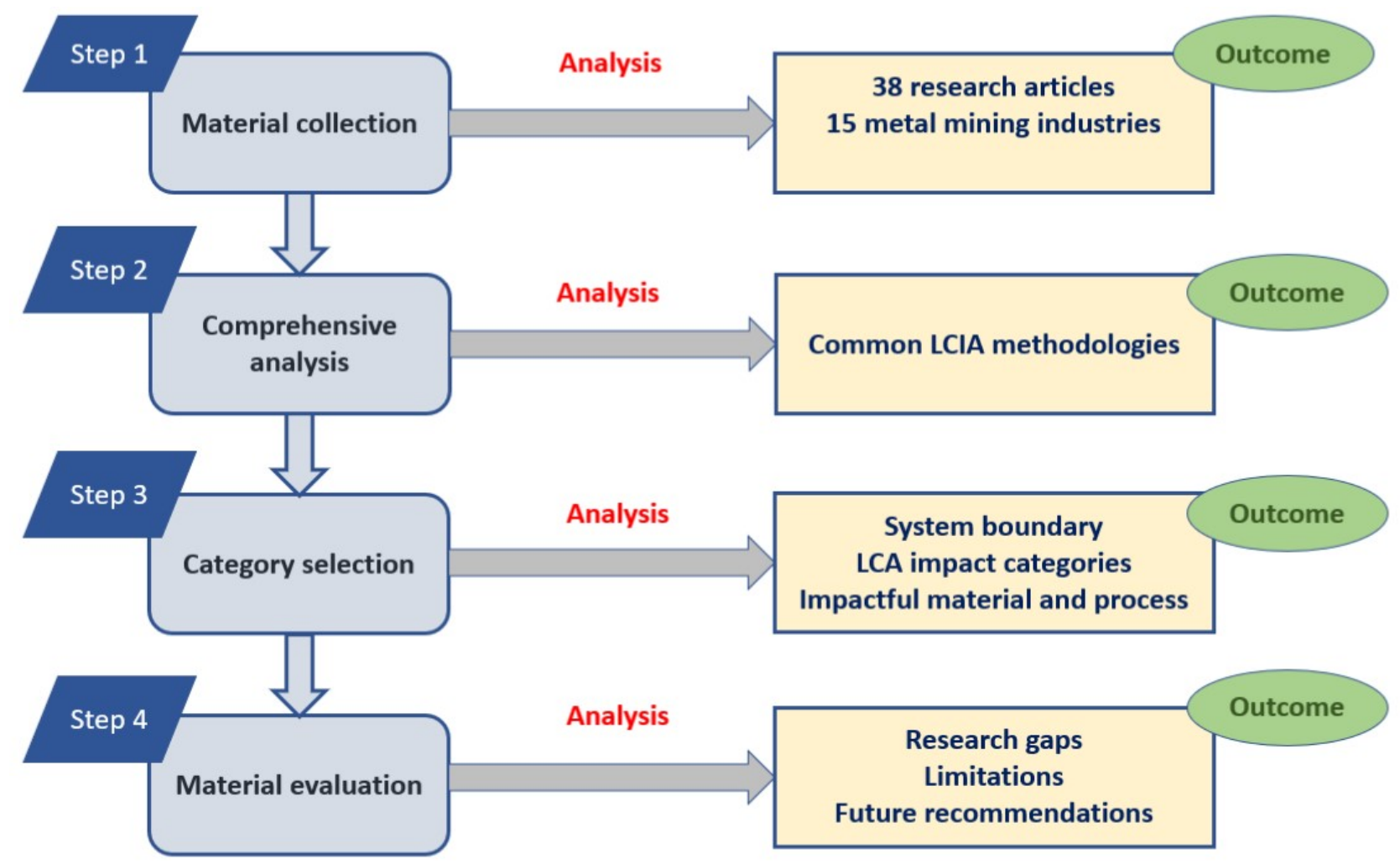

Fig. 1. Steps followed in methods to complete this review.

\section{LCA in mining industries}

This chapter describes the basics of LCA, steps, goal and scope, system boundary, software in use, and methods used for LCA analysis focused in the mining industries so far.

\subsection{Definition and steps in LCA}

Life-cycle assessment is a widely used environmental impact analysis tool which is used for many years in the scientific community to analyse the effects caused by a product, a process, or a system of processes on the environment (Grande et al., 2017). This impact analysis method aims to analyse and classify the environmental emissions based on several categorised and standardised impact assessment categories (Curran, 2012). The major steps in the life cycle assessment comprise of goal and scope definition, LCI (life cycle inventory) modelling, life cycle assessment, and results interpretation. These steps should be followed in each LCA study conducted based on the ISO (International Organization for Standardization) 14040 (Fogler and Timmons, 1998). 


\subsection{System Boundary of LCA}

The system boundary followed in a LCA study could be from cradle-to-gate, gate-to-grave, gate-to-gate, or cradle-to-grave (Stewart and Petrie, 2006). The system boundary followed in mining-based LCA studies are cradle-to-gate. Due to the lack of enough data source, it is hard to assume the end-of-life state of the processed metal. Which in turn, restricts the LCA study onto the cradle-to-gate processes (Santero and Hendry, 2016). A complete LCA study in mining comprises of ore mining, concentration and beneficiation, extraction, smelting, transportation and refining operations. However, the structure of the system boundary is also dependent on the available datasets, as they are proprietary information.

\subsection{Functional unit and goal of LCA study}

The functional unit in consideration for LCA in mining could be of $1 \mathrm{~kg}$ of selected mineral, or 1 tonne of selected mineral, or mega tonne of that selected mineral. The goal of the LCA works is to analyse the effects of a product or process based on their system boundary and categorise their emissions (Teh et al., 2017): the materials, energy (in the form of renewables and non-renewables, resources, organic and inorganic chemicals are identified as the material inputs in an LCA study. The output product, waste emissions, by-products, and emissions to soil, water, and environment are considered as material or process outputs (Althaus and Classen, 2005).

\subsection{Life cycle inventory datasets}

The life-cycle inventory datasets were collected from several sources like company reports, published literature-works, renowned databases like EcoInvent, USGS, AusLCI. However, very few datasets are focused on global context. Datasets can be presented as global datasets, regional datasets, or countryspecific datasets. For standardising the datasets, the collected sets of data are quantified and aggregated, validated, averaged, and finally represented in the form of mine irrespective datasets. The source of these datasets could be originated from mining company reports, published research works, books, media, and so on (DEE, 2017; EPA, 2018). A global dataset could be generated after data collection from several mining companies of different geographic regions, aggregating, averaging, checking, and data validation. Most of the metal life cycle inventory datasets are regional, which is confusing because technology mix, heat mix, and grid mix vary from one company to another, one country to another, and from one region to another. Another major difference is most of the metals could be mined in alternative routes and alternative techniques. It is hard and not available to get the inventory datasets for each of those mining processes.

In most cases, inventory datasets for subprocesses of the full mining process were available, which made it harder to compare among the mining processes and the metals. Also, metal mining industry datasets are dispersed in different databases which also difficult for researchers to get the life cycle inventory datasets in a go. These differences necessitate the fact that in future it would be highly beneficial to develop global datasets and database containing global metal mining datasets (Althaus et al., 2007; Althaus and Classen, 2005; Hischier et al., 2010; Long et al., 1998; Marguerite et al., 2015; Weidema et al., 2013).

\subsection{Life cycle assessment methods}

| The methods to conduct the life cycle assessment analyse-are based on ISO 14040 standards. The renowned and widely used LCA methods in mining industries are CML (Centre of Environmental Science of Leiden University of Sweden) method, TRACI (Tool for the Reduction and Assessment of Chemical and other Environmental Impacts) method, ILCD (International Reference Life Cycle Data System) method, CED (Cumulative Energy Demand) method, and IPCC (Intergovernmental Panel on 
Climate Change) method. These methods vary from one another regarding characterisation, Normalisation and weighting factors, impact categories, and geographic location. The analysed impact categories also vary among the methods. The most common midpoint indicator based (problem-oriented) impact categories are $\mathrm{HH}$ (human health, cancer and non-cancer effects), CC (climate change), eutrophication (terrestrial, marine, aquatic), acidification potential, resources depletion, land and water use, and ecotoxicity. The end-point indicator (damage oriented) impact categories are climate change, human health, ecosystems, and resources. These methods are also geography dependent like CML methods are widely used for manufacturing processes held in Europe whereas TRACI method is used for LCA studies based on USA ((JRC), 2012; Acero et al., 2015; Hischier et al., 2010; JRC European commission, 2011; Wolf et al., 2012).

The most common life cycle assessment methods utilised in mining industries were ReCiPe method, the IPCC method, and Australian Indicator method. ReCiPe method has 18 midpoints indicator-based categories and three endpoints indicator-based categories. The ReCiPe is the most updated LCA method with a minimum number of indicator scores. ReCiPe method is classified on hierarchies, individualist, and egalitarian method. Most importantly, the ReCiPe method is particularly focused on European geographic continent (Fugiel et al., 2017; Marguerite et al., 2015). Intergovernmental Panel on Climate Change (IPCC) method is specialised in greenhouse gas emissions. This method accesses the GHG effects based on 20 years, 50 years, and 100 years' time span (Hischier et al., 2010).

On the other hand, Australian Indicator method is specialised in materials and processes located in Australian geographic region. According to the best practice guide in life cycle assessment, Australian Indicator method do not contain the toxicity emission factors and the characterisation factors are based on European context, inherited from CML method. So, it is not properly focused on Australian geographic context (Lodhia and Martin, 2014; Marguerite et al., 2015). Center for Methodological Development (CML) method, developed by University of Leiden in Netherland is another well-established LCA method, where the characterisation factors are focused on the average values of global and European geographic context, with no weighting applied on it. So, the regional validity of this method could be considered as global except for the AP and POCF, which are based on European factors. International Reference Life Cycle Data System (ILCD) method is developed by the Joint Research Commission in Europe (JRC) where the impact categories are formed using the base of different renowned methods, IPCC (for climate change in 100 years' time span), USEtox (human toxicity cancer and non-cancer), CML 2002 (resource depletion) and several other methods from literature. This method follows best practice in several impact assessment categories ((JRC), 2012; European Commission -- Joint Research Centre -- Institute for Environment and Sustainability, 2010; JRC European commission, 2011).

The most discussed impact categories are CC/GHG and PED/ TER. AP, MD, waste was also assessed in many literature works, but still, there are hugely lacking regarding environmental impact categories. Due to the lack of complete life cycle inventory datasets, it was also hard to complete full LCA study for metal industries, which could be a great research focus in future. Also, as environmental impacts could not be regional, there is still needing to develop a global LCA method, which would apply to processes or system of processes for any region (Acero et al., 2015; Menoufi, 2011).

Choosing the appropriate LCA method is a crucial step in conducting an LCA. However, this choice is dependent upon several factors such are geography, characterization and Normalisation factors for environment, and industrial sector choice. In mining industries, the most commonly practiced method is the ReCiPe method and ILCD method (discussed in Table 1).

\section{Table 1}

Summary of LCA techniques used in previous studies. 


\begin{tabular}{|c|c|c|}
\hline Metal & Method & Impact categories \\
\hline $\begin{array}{l}\text { Aluminium (Farjana et al., 2019a; Nunez } \\
\text { and Jones, 2016; Paraskevas et al., 2016; } \\
\text { Tan and Khoo, 2005) }\end{array}$ & $\begin{array}{l}\text { EDIP, UMIP, ReCiPe, } \\
\text { ILCD, TRACI }\end{array}$ & $\begin{array}{l}\text { GWP, AP, HT, resources, waste, FFD, } \\
\text { EUEm, ODP, POCP, WF, }\end{array}$ \\
\hline Cemented carbide (Furberg et al., 2019) & & $\begin{array}{l}\text { TE, OD, FEW (Freshwater } \\
\text { ecotoxicity), CC, POF, WD }\end{array}$ \\
\hline $\begin{array}{l}\text { Coal (Adiansyah et al., 2017; Burchart- } \\
\text { Korol et al., 2016; Guimarães da Silva et al., } \\
\text { 2018; Zhang et al., 2018) }\end{array}$ & $\begin{array}{l}\text { IPCC, } \quad \text { ReCiPe, } \\
\text { Australian Indicator }\end{array}$ & AP, GWP, Resource, waste, dust \\
\hline $\begin{array}{l}\text { Copper (Ekman Nilsson et al., 2017; Haque } \\
\text { and Norgate, 2014; Memary et al., 2012; } \\
\text { Norgate, 2001; Northey et al., 2013) }\end{array}$ & $\begin{array}{l}\text { ReCiPe, } \\
\text { Indicator }\end{array}$ & GWP, AP, TED, \\
\hline $\begin{array}{l}\text { Ferroalloy (Bartzas and Komnitsas, 2015; } \\
\text { Haque and Norgate, 2013) }\end{array}$ & & GWP, AP, PED \\
\hline $\begin{array}{l}\text { Gold (Chen et al., 2018; Haque and } \\
\text { Norgate, 2014; Norgate and Haque, 2012) }\end{array}$ & $\begin{array}{ll}\text { ReCiPe, } & \text { Australian } \\
\text { Indicator } & \end{array}$ & $\begin{array}{l}\text { Energy, GWP, water use, waste, TA, HT, } \\
\text { PMF, ME, FD, }\end{array}$ \\
\hline $\begin{array}{l}\text { Iron (Ferreira and Leite, 2015; Gan and } \\
\text { Griffin, 2018; Haque and Norgate, 2015; } \\
\text { Norgate and Haque, 2010) }\end{array}$ & $\begin{array}{l}\text { IPCC, } \quad \mathrm{ReCiPe}, \\
\text { Australian Indicator }\end{array}$ & $\begin{array}{l}\text { GHG, human health, ecosystem, } \\
\text { resources, GER }\end{array}$ \\
\hline Manganese (Westfall et al., 2016) & CML 2001 & GWP, AP, POCP, water use, waste \\
\hline Magnesium oxide (Ruan and Unluer, 2016) & EcoIndicator 99 & Human health, ecosystem, resources, \\
\hline $\begin{array}{l}\text { Nickel (Khoo et al., 2017; Mistry et al., } \\
\text { 2016) }\end{array}$ & $\begin{array}{lr}\text { IMPACT } & 2002+, \\
\text { ReCiPe, } & \text { Australian } \\
\text { Indicator, CML } 2001\end{array}$ & GWP, PED \\
\hline $\begin{array}{l}\text { Rare earth element (Lima et al., 2018; } \\
\text { Zaimes et al., 2015) }\end{array}$ & $\begin{array}{ll}\text { IMPACT } & 2002+, \\
\text { ReCiPe, CED } & \\
\end{array}$ & GER, GWP, ODP, carcinogens \\
\hline Silver (Farjana et al., 2019b, 2019d) & $\underline{\text { ILCD, CED }}$ & GWP, HT. \\
\hline $\begin{array}{l}\text { Steel (Burchart-Korol, 2013; Norgate et al., } \\
\text { 2007; Renzulli et al., 2016) }\end{array}$ & $\begin{array}{l}\text { IPCC, ReCiPe, CED, } \\
\text { ILCD }\end{array}$ & GWP, AP, TED, dust, ODP, PMF \\
\hline $\begin{array}{l}\text { Titanium oxides (Shahjadi Hisan Farjana et } \\
\text { al., 2018a) }\end{array}$ & ILCD, CED & $\begin{array}{l}\text { GWP, AP, FAE, MAE, EU, MRD, LU, } \\
\text { Water, TED }\end{array}$ \\
\hline $\begin{array}{l}\text { Uranium (Shahjadi Hisan Farjana et al., } \\
\text { 2018b; Haque and Norgate, 2014; Norgate } \\
\text { et al., 2014; Parker et al., 2016) }\end{array}$ & $\begin{array}{l}\text { ILCD, Australian } \\
\text { Indicator, CED }\end{array}$ & $\begin{array}{l}\text { GWP, AP, FAE, MAE, EU, MRD, LU, } \\
\text { Water, TED }\end{array}$ \\
\hline $\begin{array}{l}\text { Zinc (Qi et al., 2017; Van Genderen et al., } \\
\text { 2016) }\end{array}$ & ReCiPe, CML 2001 & GWP, AP, EU, POCP, OD, PED, \\
\hline
\end{tabular}

The identification of the best practice methods under different impact categories are discussed below in Table 2. Table 2 also elaborates the quantification techniques for each of the major environmental impact assessment categories.

\section{Table 2}

Quantification and best practice in LCA methods (Marguerite et al., 2015).

\begin{tabular}{|l|l|l|}
\hline Impact categories & Elements used for quantification & Best practice methods \\
\hline Climate change & $\begin{array}{l}\text { Quantification es based on the human } \\
\text { activities on climate based on greenhouse } \\
\text { gas emissions. This is most commonly } \\
\text { accounted for carbon dioxide, methane, and } \\
\text { nitrous oxide emissions. }\end{array}$ & $\begin{array}{l}\text { IPCC method to calculate GHG } \\
\text { emissions. }\end{array}$ \\
\hline Resources depletion & Quantifies the depletion of natural & CML method and ILCD method \\
\hline
\end{tabular}




\begin{tabular}{|c|c|c|}
\hline & $\begin{array}{l}\text { resources from the earth, based on } \\
\text { concentration of reserve and } \\
\text { deaccumulation rate/quantity of fuels/ ratio } \\
\text { of annual production to available reserve/ } \\
\text { damage to resource based on increased cost } \\
\text { of extraction. }\end{array}$ & $\begin{array}{l}\text { based on concentration of reserve } \\
\text { and deaccumulation rate. }\end{array}$ \\
\hline Eutrophication & $\begin{array}{l}\text { Quantification es based on the macro } \\
\text { nutrients released on the environment- air, } \\
\text { water, soil. It can be aquatic and terrestrial. } \\
\text { Aquatic eutrophication is quantified based } \\
\text { on accelerated algae growth, reduced } \\
\text { sunlight infiltration and oxygen depletion. } \\
\text { Terrestrial eutrophication is quantified } \\
\text { based on increase susceptibility of plants to } \\
\text { diseases. }\end{array}$ & $\begin{array}{l}\text { CML and IMPACT } 2002+\text { which } \\
\text { quantifies based on stoichiometric } \\
\text { nutrification potential applicable to } \\
\text { both categories. }\end{array}$ \\
\hline Acidification & $\begin{array}{l}\text { Quantification es-based on the acidifying } \\
\text { impacts based on when acid precursor } \\
\text { compounds are released onto the } \\
\text { environment and deposited on land } \\
\text { (terrestrial) or water (aquatic). } \\
\text { Quantification is mainly based on nitrous } \\
\text { oxides, sulphur oxides, sulphuric acid and } \\
\text { ammonia. }\end{array}$ & $\begin{array}{l}\text { CML and ILCD method based on } \\
\text { critical load exceedance method of } \\
\text { hazard index (HI) method. }\end{array}$ \\
\hline $\begin{array}{l}\text { Human toxicity and } \\
\text { eco-toxicity }\end{array}$ & $\begin{array}{l}\text { Quantifies the impact of toxicity substance } \\
\text { released on land, water, and environment. } \\
\text { Quantification is based on using pesticides, } \\
\text { heavy metals, hormones, and organic } \\
\text { chemicals. }\end{array}$ & $\begin{array}{l}\text { USEtox, ILCD, ReCiPe, and } \\
\text { IMPACT 2002+. }\end{array}$ \\
\hline $\begin{array}{l}\text { Photochemical } \\
\text { ozone formation }\end{array}$ & $\begin{array}{l}\text { Quantifies the impacts based on impacts } \\
\text { from increase on ozone formation in } \\
\text { troposphere. The main criteria are the } \\
\text { emission of nitrous oxides, carbon } \\
\text { monoxide, and those which impacts on } \\
\text { ozone formation. }\end{array}$ & $\begin{array}{l}\text { CML method, based on simplified } \\
\text { description of atmospheric } \\
\text { transport. }\end{array}$ \\
\hline $\begin{array}{l}\text { Particulate matter } \\
\text { formation }\end{array}$ & $\begin{array}{l}\text { Quantification is based on the emissions on } \\
\text { air which are harmful for human health. In } \\
\text { different LCIA methods, these are } \\
\text { characterized under different impact } \\
\text { categories. }\end{array}$ & 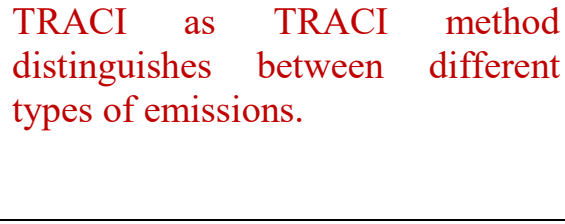 \\
\hline Land use & $\begin{array}{l}\text { Quantification is es-based on the amount of } \\
\text { land use in LCA and its effects on } \\
\text { biodiversity. }\end{array}$ & $\begin{array}{l}\text { Currently no best practice methods } \\
\text { for land use as no single method } \\
\text { quantifies all levels of biodiversity. }\end{array}$ \\
\hline Ozone depletion & $\begin{array}{l}\text { Quantifies the impact based on the } \\
\text { reduction in concentration of ozone. }\end{array}$ & $\begin{array}{l}\text { Ozone depletion factors published } \\
\text { by the World Meteorological } \\
\text { Organizations (WMO). }\end{array}$ \\
\hline Ionizing radiation & $\begin{array}{l}\text { Quantifies the impact of radioactive species } \\
\text { (radionuclides) on air and water. }\end{array}$ & $\begin{array}{l}\text { ILCD or ReCiPe method based on } \\
\text { the quantification of radioactive } \\
\text { impact on human health. }\end{array}$ \\
\hline
\end{tabular}




\subsection{Geographic region under consideration}

| Regarding geographic region, a number of studies different research works-were focused on different regions, but the most commons were based on two countries - Australia and China. Many research on LCA is being carried out in Australian geographic context- aluminium, coal, copper, ferroalloy, gold, iron, nickel, titanium oxides, and Uranium. For mining in China, LCA worked-on aluminium, coal, iron, and zinc. Impact categories were also different based on metal specific industries, as they were originated from different geographic context and used different LCA methods (Mutchek et al., 2016; Stewart and Petrie, 2006; Teh et al., 2017).

\subsection{Allocation techniques}

Allocation technique was also-required in many of the LCA studies which produce a significant number of by-products. The allocation technique could be of mass-based, economy-based, or can be used as a combination of both mass and economy. The characterisation and normalisation factors for allocation techniques vary among the LCA software like SimaPro or Gabi. According to the trend followed by the metal mining industries, it is best practice to avoid coproduct allocation whenever possible. It was assumed that no products were going outside the system other than the main product. However, in many processes, it cannot be avoided. In those cases, it is better to use the allocation technique focused on both mass and economy, as - Because, the mass can vary from among-one mining company/site to another, production technique could also vary. In addition, Also, results between mass and economy could vary in a large huge-amount. Hence, So, it is best to calculate using both technique, and then data aggregation and averaging could be done to allocate proper values (Raugei and Ulgiati, 2009; Santero and Hendry, 2016; Weidema and Norris, 2002).

\subsection{Software in use}

The software which was most widely used popular in mining industries were SimaPro and Gabi. Between this two, SimaPro seems to be more popular. One of the reasons for this popularity could be the-AusLCI database which is integrated with SimaPro software and containing s-many metal mining LCA datasets focused particularly for Australia made SimaPro a widely accepted choice. The analysis results generated by both SimaPro and Gabi should produce reasonably similar outcome considering similar analysis techniques and databases are used, however, that is also subject to research and validation. This can show another prospective research direction, that conducting life cycle assessment using both SimaPro and Gabi, using the same methods, and match their results based on each impact categories. There may be would-some variation because between-among the datasets generated from different companies, the characterisation and normalisation factors would also be different (Goedkoop et al., 2014; Li et al., 2018; Nunez and Jones, 2016; PRé, 2018).

\section{Impact Analysis based on Metal Mining Industries}

| This chapter describes the LCA research-conducted on the key mining and metalmineral processing industries, their analysis methods, key findings, results, limitations, and future recommendations. The major industries involve aluminum, coal, copper, ferroalloy, gold, iron, nickel, rare earth elements, stainless steel, uranium, and zinc. The last subsection identifies describes LCA research of five metals together, which have very few researches involved so far. Those includes with no or very few research output which are cemented carbide, manganese, magnesium oxide, and titanium oxides. 


\subsection{LCA in aluminium mining}

Aluminium is a lightweight and corrosion resistant metal, which are used in automobile industries, aerospace industries, beverage, making alloys, and electronics industries. The top countries which are mining and producing aluminium on a massive seale are China, Russia, Canada, India, Australia. Aluminium production consists of four major steps: bauxite ore mining, alumina production from Bayer process, alumina smelting from Hall Heroult process, and alumina refining. Table 3 describes the major findings and recommendations from the researches conducted related to LCA of this metal.

There were threeare four major studies conducted in the LCA of aluminium production processes. Tan et al. analysed LCA of the aluminium supply chain which consists of the refinery, smelter, and a casting plant. The geographical coverage was Australia, and it was a cradle to gate LCA study. The analysis was done using SimaPro with EDIP (Environmental Design of Industrial Products). The impact categories which were assessed, global warming potential (GWP), acidification potential (AP), human toxicity (HT), resources, built waste. Tan considered four scenarios including the baseline mode of operation, and other scenarios were constructed after modifying the scrap metal and red mud. Their results revealed that electricity use in smelting and refining process is mainly responsible for GWP (Global Warming Potential) and HT (Human Toxicity). AP (Acidification Potential) is due to sulfur dioxide $\left(\mathrm{SO}_{2}\right)$ generation from the power plant and transportation system. Their study revealed that reducing the scrap metal and red mud could significantly reduce the impacts from aluminium production (Tan and Khoo, 2005).

Paraskevas et al. analysed aluminium production after comparing electricity mix of 29 countries. Their datasets are originated from EcoInvent and USGS databases whereas analysed using SimaPro software and ReCiPe method. Electricity generated from hydropower, coal, gas, nuclear, biofuel, geothermal, solar are considered there. They assumed that electricity is $100 \%$ grid dependent and not traded among the countries. According to Paraskevas, amount of greenhouse gas emissions from aluminium production is $0.45 \mathrm{Gt} \mathrm{CO}_{2}$ eq. Aluminium production requires $66 \mathrm{MJ}$ energy per $\mathrm{kg}$. More than eighty percent $(80 \%)$ is for electricity generation in Hall Heroult process. They identified that countries with high coal and oilrich mix have higher emission results rather than countries using cleaner technologies. They have also stated that countries with similar electricity mix show similar GHG (Greenhouse Gas Emission) results (Paraskevas et al., 2016).

Another study conducted by Nunez et al. where the datasets are collected by the International Aluminium Institute (IAI) have studied primary aluminium production process and used Gabi software. The geographic region under consideration was global and global minus China. Nunez considered six midpoints indicator-based categories: GWP (global warming potential), AP (acidification potential), FFD (fossil fuel depletion), EU (eutrophication), ODP (ozone depletion potential), POCP (photo-oxidant creation potential), and WSP (water scarcity potential). Their identification also reveals the fact that highest contribution of GHG is from alumina refining and electrolysis process. Direct emissions from the electrolysis process also contribute largely to GHG (Nunez and Jones, 2016). Farjana et al. studied the cradle-to-gate complete LCA of four major steps eoncerning from the bauxite mining to alumina refining processes. They have also conducted the sensitivity analysis among the quantity of fossil fuel used based on process heat generation. As ecording to the study reports, electricity consumption during alumina smelting has the highest impact on environment. Process heat generation has also significantconsiderable impact on the environment. The climate change effect from bauxite mining is $0.079 \mathrm{~kg} \mathrm{CO}_{2}$ eq., alumina production is $1.23 \mathrm{~kg} \mathrm{CO}_{2}$ eq., alumina smelting is $10.91 \mathrm{~kg} \mathrm{CO}_{2}$ eq., and alumina refining is $0.27 \mathrm{~kg} \mathrm{CO}_{2}$ eq. (Farjana et al., 2019a) 
Table 3

Summary of the findings and recommendations for LCA of aluminum mining.

\begin{tabular}{|c|c|c|}
\hline Study reference & Key findings & Recommendation \\
\hline $\begin{array}{l}\text { LCA focused on } \\
\text { Australia (Tan and Khoo, } \\
\text { 2005) }\end{array}$ & $\begin{array}{l}\text { Electricity use in smelting and refining } \\
\text { process is mainly responsible for GWP }\end{array}$ & $\begin{array}{l}\text { Reducing the scrap metal and red } \\
\text { mud could significantly reduce } \\
\text { the impacts }\end{array}$ \\
\hline $\begin{array}{l}\text { LCA comparing } 29 \\
\text { countries (Paraskevas et } \\
\text { al., 2016) }\end{array}$ & $\begin{array}{l}\text { Identified that countries with high coal } \\
\text { and oil-rich mix have higher emission } \\
\text { results and countries with similar } \\
\text { electricity mix show similar GHG } \\
\text { results }\end{array}$ & $\begin{array}{l}\text { To reduce the environmental } \\
\text { impacts from aluminium } \\
\text { production, it should start by } \\
\text { focussing on China due to their } \\
\text { energy mix. All the aluminium } \\
\text { producing countries should focus } \\
\text { on using the cleaner resources. }\end{array}$ \\
\hline $\begin{array}{l}\text { LCA on global aluminum } \\
\text { production (Nunez and } \\
\text { Jones, 2016) }\end{array}$ & $\begin{array}{l}\text { reveals the fact that highest } \\
\text { contribution of GHG is from alumina } \\
\text { refining and electrolysis process. } \\
\text { Direct emissions from the electrolysis } \\
\text { process also contribute largely to GHG }\end{array}$ & $\begin{array}{l}\text { Due to increased production of } \\
\text { aluminum in China, more LCI } \\
\text { datasets are required for } \\
\text { modelling to enhance the } \\
\text { reliability of the impact } \\
\text { assessment about aluminum } \\
\text { production. }\end{array}$ \\
\hline $\begin{array}{l}\text { LCA on global aluminum } \\
\text { production (Farjana et al., } \\
\text { 2019a) }\end{array}$ & $\begin{array}{l}\text { Electricity and process heat } \\
\text { consumption in alumina smelting has } \\
\text { the highest impact. }\end{array}$ & $\begin{array}{l}\text { Alternative energy generation } \\
\text { source and improvement in } \\
\text { energy efficiency would be } \\
\text { beneficial for sustainability. }\end{array}$ \\
\hline
\end{tabular}

\subsection{LCA in coal mining}

Coal is a widely used fossil fuel used for electricity generation or process heat generation. Coal is extracted on the earth crust based on open cast and underground mining. The major miners of coal are Ukraine, Kazakhstan, South Africa, China, United States, and Australia. Coal can be produced from open pit mining or underground mining. There are a few steps involved in coal production while major processes are mining, transportation, and comminution. In the mining step, surface soil is removed for drilling and detonation. Then the inert materials are removed, and coal layers are drilled. Then the coal layers undergo detonation and mined areas are recovered. Then the run of mines undergoes the loading and transportation. The run of mines is then stocked, crushed, and shifted. Table $\mathbf{4}$ describes the major findings and recommendations from the research conducted related to LCA of this metal.

Korol et al. developed and utilised a computational LCA for coal mining in Poland. They assessed the GHG using the IPCC method (20 years, 100 years, and 500 years). Analysis of damage categories was done using the ReCiPe method. Their study identified that the largest contributor to GHG is fossil fuel and methane emissions for electricity use, processing of waste, heat, and steel supports. Among the three range of years, the highest range of emissions was from 20 years span, that is $85 \mathrm{~kg} \mathrm{CO}_{2}$ eq per $\mathrm{kg}$. In this time frame, highest contributor for GHG is methane emissions which could be generated from electricity, heat and steel support associated with the ventilation process (Burchart-Korol et al., 2016). In another study, Adiansyah et al. compare coal mining tailings management strategies using LCA. They have used hybrid LCA method comprised of Australian Indicator and ReCiPe method. The strategies involved belt press, tailings paste, thickened tailings. They found that electrical energy is the greatest contributor to environmental emissions from coal mining. The analysis is done using three case scenarios- tailings with 
the low amount of water, tailing paste with much solids, and the base case with high amount of water (Adiansyah et al., 2017). Zhang et al studied opencast coal mining operation in China. The functional unit was 100 ton of coal. The system boundary includes stripping, mining, transportation, processing, and reclamation. The impact categories which were considered: resources, acidification, GWP, waste, and dust. According to Zhang, the most impactful category was dust, followed by GWP and acidification. For 1 ton of coal production, the GWP was $7331.7 \mathrm{~kg} \mathrm{CO} 2$ eq (Zhang et al., 2018). Silva et al. analysed the surface coal mine located in Brazil. Their system boundary includes mining, transportation system, comminution, recovery, production, and final transportation. Their study found that diesel oil is the significant parameter which emits carbon dioxide, methane, and ammonia. They have also conducted a sensitivity analysis based on fugitive emission factors for diesel oil, electricity, and transport (Guimarães da Silva et al., 2018).

Table 4

Summary of the findings and recommendations for LCA of coal mining.

\begin{tabular}{|l|l|l|}
\hline Study reference & Key findings & Recommendation \\
\hline $\begin{array}{l}\text { PCA for coal mining in } \\
\text { et al., 2016) }\end{array}$ & $\begin{array}{l}\text { tThe largest contributor to GHG is } \\
\text { fossil fuel and methane emissions for } \\
\text { electricity use, processing of waste, } \\
\text { heat }\end{array}$ & $\begin{array}{l}\text { The impacts can be reduced using } \\
\text { alternative fuels in steel } \\
\text { production. Pollution prevention } \\
\text { methods should be applied to } \\
\text { reduce emissions. }\end{array}$ \\
\hline $\begin{array}{l}\text { LCA in respect of } \\
\text { Australia (Adiansyah et } \\
\text { al., 2017) }\end{array}$ & $\begin{array}{l}\text { Electrical energy is the greatest } \\
\text { contributor to environmental emissions } \\
\text { from coal mining }\end{array}$ & $\begin{array}{l}\text { The thickened tailing in the coal } \\
\text { mining tailing management could } \\
\text { reduce the environmental burdens. }\end{array}$ \\
\hline $\begin{array}{l}\text { LCA focused on coal } \\
\text { production in China } \\
\text { (Zhang et al., 2018) }\end{array}$ & $\begin{array}{l}\text { the most impactful category was dust, } \\
\text { followed by GWP and acidification }\end{array}$ & $\begin{array}{l}\text { Increase in tire performance, } \\
\text { transportation efficiency, low- } \\
\text { carbon power development, and } \\
\text { advancement in mining } \\
\text { technology will be beneficial to } \\
\text { reduce the impacts. }\end{array}$ \\
\hline $\begin{array}{l}\text { LCA based on Brazil } \\
\text { (Guimarães da Silva et } \\
\text { al., 2018) }\end{array}$ & $\begin{array}{l}\text { diesel oil is the significant parameter } \\
\text { anich emits carbon dioxide, methane, } \\
\text { and ammonia }\end{array}$ & $\begin{array}{l}\text { This work will contribute to the } \\
\text { detailed LCA analysis of coal } \\
\text { mining in Brazil to implement the } \\
\text { measures related to diesel oil. }\end{array}$ \\
\hline
\end{tabular}

\subsection{LCA in copper mining}

Copper is a valuable $\mathrm{n}$ important-metal used for their conductivity properties and corrosion resistant properties. They are widely used for electrical wiring, construction, heat exchangers, and electronics. The producers of copper are United States, Chile, and Australia. Copper is extracted using ore mining, beneficiation. If it goes through pyrometallurgical extraction, then it passes through smelting, converting, fire refining, and electrorefining. If the ore goes through hydrometallurgical extraction, then it has leaching, solvent extraction, and electrowinning. Table 5 describes the major findings and recommendations from the research conducted related to LCA of this metal.

Norgate conducted LCA based on pyrometallurgical and hydrometallurgical copper production. They assessed and compared the impacts from process parameters, ore grade, energy consumed for electricity generation, and electricity generation capacity. The assessed impact categories were GWP, AP. They 
showed that solvent extraction and electrowinning processes of hydrometallurgical copper production has a higher impact over pyrometallurgical copper production (Norgate, 2001). Memary et al. conducted a time series analysis of copper production. They examined the environmental effects from copper mining and smelting from 1940 to 2008 through a novel approach. They had conducted a cradle-to-gate LCA study based on datasets from five Australian copper mine. They showed that carbo footprint from all mines ranged from $800 \mathrm{kt} \mathrm{CO}_{2}$ eq to $1922 \mathrm{kt} \mathrm{CO}_{2}$ eq. They showed that copper mining and milling were the most crucial part to reduce GWP (Memary et al., 2012). Northey et al. conducted LCA of copper mining and stated that average energy intensity ranges from 10 to $70 \mathrm{GJ} / \mathrm{t} \mathrm{Cu}$. GHG ranges from 1 to $9 \mathrm{t}$ $\mathrm{CO}_{2}$ eq/t $\mathrm{Cu}$. This large variation was due to the form of copper produced, ore grade, sources of fuel, and electrical energy (Northey et al., 2013). Haque et al. conducted a comparative LCA study among in-situ leaching based production of copper, gold, and uranium. Their study was conducted based on Australian Impact method using SimaPro software. They showed that for copper mining, solvent extraction and electrowinning played a significant role in GHG. For good field related activities, electricity was the main source of GHG and also the sulfuric acid used for leaching (Haque and Norgate, 2014). Nilsson compared the carbon footprint of copper mining based on LCA while the sources are both primary and secondary. The value of carbon footprint ranges from 1.1 to $8.5 \mathrm{~kg} \mathrm{CO}_{2} \mathrm{eq} / \mathrm{kg} \mathrm{Cu}$. The literature shows that it could be 2.1 to $8 \mathrm{~kg} \mathrm{CO}$ eq $/ \mathrm{kg} \mathrm{Cu}$ for primary copper. From the secondary source, the carbon footprint ranges from 0.1 to $1.9 \mathrm{~kg} \mathrm{CO}_{2} \mathrm{eq} / \mathrm{kg} \mathrm{Cu}$. The reason for this wide range of variation was the material quality, the metallurgical process, and transportation distance (Ekman Nilsson et al., 2017). Farjana et al. analyzed the gold-silver-lead-zinc-copper beneficiation process, which summarizes that gold-silver beneficiation has greatest impact over the other metal in these joint production which is due to the electricity usage through fossil fuel consumption (Farjana et al., 2019b).

Table 5

Summary of the findings and recommendations for LCA of copper mining.

\begin{tabular}{|l|l|l|}
\hline Study reference & Key findings & Recommendation \\
\hline $\begin{array}{l}\text { LCA on global copper } \\
\text { production (Norgate, }\end{array}$ & $\begin{array}{l}\text { solvent extraction and electrowinning } \\
\text { processes of hydrometallurgical copper } \\
\text { production has a higher impact. }\end{array}$ & $\begin{array}{l}\text { They conducted a sensitivity } \\
\text { analysis based on by varying 30\% } \\
\text { of process power consumption } \\
\text { and transport mode and distance, } \\
\text { which indicates some } \\
\text { improvement the } \\
\text { environmental emissions. }\end{array}$ \\
\hline $\begin{array}{l}\text { LCA on Australian } \\
\text { copper mining (Memary } \\
\text { et al., 2012) }\end{array}$ & $\begin{array}{l}\text { copper mining and milling were the } \\
\text { most crucial part to reduce GWP. }\end{array}$ & $\begin{array}{l}\text { The mining production impacts } \\
\text { related to regional energy } \\
\text { consideration should be carefully } \\
\text { considered with the geography. }\end{array}$ \\
\hline $\begin{array}{l}\text { LCA on copper mining } \\
\text { (Northey et al., 2013) }\end{array}$ & $\begin{array}{l}\text { The large variation in GHG was due to } \\
\text { the form of copper produced, ore } \\
\text { grade, sources of fuel, and electrical } \\
\text { energy. }\end{array}$ & $\begin{array}{l}\text { Recommendations made for the } \\
\text { companies for improving mining } \\
\text { datasets through indicating } \\
\text { detailed energy consumption } \\
\text { scenario for each stage of the } \\
\text { metal production. }\end{array}$ \\
\hline $\begin{array}{l}\text { LCA of copper mining in } \\
\text { Australia (Haque and } \\
\text { Norgate, 2014) }\end{array}$ & $\begin{array}{l}\text { For good field related activities, } \\
\text { electricity was the main source of } \\
\text { GHG, and the sulfuric acid used for } \\
\text { leaching. }\end{array}$ & $\begin{array}{l}\text { Electricity generated from the } \\
\text { renewable energy resources such } \\
\text { as solar energy will beneficial for } \\
\text { reducing impacts from in-situ } \\
\text { leaching. }\end{array}$ \\
\hline $\begin{array}{l}\text { LCA of global copper } \\
\text { mine (Ekman Nilsson et }\end{array}$ & $\begin{array}{l}\text { The reason for this wide range of } \\
\text { variation in GHG was the material }\end{array}$ & $\begin{array}{l}\text { In case of the advancement of the } \\
\text { technology for efficient recovery }\end{array}$ \\
\hline
\end{tabular}




\begin{tabular}{|l|l|l|}
\hline al., 2017) & $\begin{array}{l}\text { quality, the metallurgical process, and } \\
\text { transportation distance. }\end{array}$ & of metals, the impact will reduce. \\
\hline $\begin{array}{l}\text { LCA of gold-silver-lead- } \\
\text { zinc-copper beneficiation } \\
\text { (Farjana et al., 2019b) }\end{array}$ & $\begin{array}{l}\text { Gold-silver beneficiation has highest } \\
\text { impact over the other metals }\end{array}$ & $\begin{array}{l}\text { Modification in the electricity grid } \\
\text { mix to enhance the energy } \\
\text { efficiency will be helpful to } \\
\text { reduce environmental burdens. }\end{array}$ \\
\hline
\end{tabular}

\subsection{LCA in ferroalloy mining}

Ferroalloy is iron bearing alloys which also have a higher proportion of metals. They can make alloys including chromium, manganese, molybdenum, silicon. It is mostly They are found and produced in China, South Africa, Ukraine, Kazakhstan. Table 6 describes the major findings and recommendations from the research conducted related to LCA of this metal.

Haque et al. studied the LCA of ferroalloys. These alloys were iron bearing material alloyed in conjunction with manganese, chromium, silicon, and molybdenum. They studied the environmental impacts in respect of Australia, using the Tasmanian electricity GHG emissions factors. According to their results, GHG was $1.8 \mathrm{t} \mathrm{CO}_{2} \mathrm{eq} / \mathrm{t} \mathrm{FeMn}, 2.8$ t CO $2 \mathrm{eq} / \mathrm{t} \mathrm{SiMn}, 3.4 \mathrm{t} \mathrm{CO}$ eq/t FeSi, $13.9 \mathrm{t} \mathrm{CO}_{2} \mathrm{eq} / \mathrm{t}$ $\mathrm{FeNi}$, and $3 \mathrm{t} \mathrm{CO}_{2} \mathrm{eq} / \mathrm{t} \mathrm{FeCr}$. This large variation in $\mathrm{GHG}$ was due to their electricity use, fossil fuel consumption, grade of ferroalloys produced (Haque and Norgate, 2013). Bartzas et al. conducted an LCA study based on ferronickel production with datasets collected from mines in Greece. They assessed GWP, AP, and PED based on three different case scenarios. The scenarios were dependent on energy sources and mode of operation in smelting and refining. They showed that environmental impacts could significantly be reduced with renewable energy use instead of fossil fuel. In the normal scenario, the GHG was $12.6 \mathrm{t} \mathrm{CO}_{2} \mathrm{eq} / \mathrm{t} \mathrm{FeNi}$ while in renewable energy scenario it could be $8.24 \mathrm{t} \mathrm{CO}_{2} \mathrm{eq} / \mathrm{t} \mathrm{FeNi}$. They also found that the smelting and refining stage consumes the highest amount of energy, while ore mining and beneficiation contributed the least (Bartzas and Komnitsas, 2015).

Table 6

Summary of the findings and recommendations for LCA of ferroalloy mining.

\begin{tabular}{|c|c|c|}
\hline Study reference & Key findings & Recommendation \\
\hline $\begin{array}{l}\text { LCA of ferroalloy in } \\
\text { respect of Australia } \\
\text { (Haque and Norgate, } \\
\text { 2013) }\end{array}$ & $\begin{array}{l}\text { The large variation in GHG was due to } \\
\text { their electricity use, fossil fuel } \\
\text { consumption, grade of ferroalloys } \\
\text { produced. }\end{array}$ & $\begin{array}{l}\text { Renewable carbon like biochar } \\
\text { can be blended with fossil fuels } \\
\text { like coke or coal to replace these } \\
\text { fossils. }\end{array}$ \\
\hline $\begin{array}{l}\text { LCA of ferroalloy in } \\
\text { respect of Greece } \\
\text { (Bartzas and Komnitsas, } \\
\text { 2015) }\end{array}$ & $\begin{array}{l}\text { The environmental impacts could } \\
\text { significantly be reduced with } \\
\text { renewable energy use instead of fossil } \\
\text { fuel. The smelting and refining stage } \\
\text { consumes the highest amount of } \\
\text { energy, while ore mining and } \\
\text { beneficiation contributed the least. }\end{array}$ & $\begin{array}{l}\text { Green energy utilization would be } \\
\text { the best possible solution to get } \\
\text { better environmental results in } \\
\text { each aspect. }\end{array}$ \\
\hline
\end{tabular}

\subsection{LCA in gold mining}

Gold has a bright yellow colour. Due to malleability and conductivity, gold is a precious metal which is popular metal of precious jewellery, currency, or in electronic applications. Australia has the highest amount of gold mine deposit, similar like South Africa, and Russia. From the gold mine, the gold ores are gone through comminution stage comprises of crushing and grinding. If it is refractory ore then 
consequentially undergoes flotation, roasting, pressure oxidation, bio-oxidation, regrinding, smelting, and refining. If the gold ore is non-refractory or free-milling ore, then it undergoes extraction, cyanidation (tank or heap), recovery, stripping, electrowinning, smelting, and refining. Table 7 describes the major findings and recommendations from the research conducted related to LCA of this metal.

Norgate et al. analysed gold production processes both from refractory and non-refractory ores. The impact categories under consideration were energy, GHG, water, and waste. They found that refractory ore has the highest impact on mining and comminution stage due to electricity consumption. $61 \%$ of the total GHG is from refractory ores (Norgate and Haque, 2012). Chen et al. analysed the life cycle impact of gold mining processes in China where the impact categories were CC, TAP, HT, PMF (Particulate Matter Formation), FFD (fossil fuel depletion). The analysis was done by midpoint and endpoint-based ReCiPe method. They found that the largest impact is on the metal depletion category from mining due to energy consumption and emissions. For climate change, electricity and diesel were the largest contributors. Climate change impact was $5.55 \mathrm{E} 4 \mathrm{~kg} \mathrm{CO}_{2}$ eq (Chen et al., 2018). Haque et al. conducted a comparative LCA study among in-situ leaching based production of copper, gold, and uranium. Their study was conducted based on Australian Impact method using SimaPro software. They showed that for gold mining, activities relating well field impacts mostly about $39 \%$ of total GHG, where $56 \%$ was from gold extraction and metal production, and 5\% were due to chemical use (Haque and Norgate, 2014). Farjana et al. analyzed the gold-silver-lead-zinc-copper beneficiation process, which summarizes that gold-silver beneficiation has greatest impact over the other metal in these joint production which is due to the electricity usage through fossil fuel consumption (Farjana et al., 2019b). Farjana et al. also analyzed the comparative life cycle environmental impacts of gold-silver refining operations whilewhere the ore is extracted from co-production of gold-silver and or the combined production of gold-silver-lead-zinccopper. Results from that study showed that From this study it is evident that gold refining from the goldsilver production have significantnoteworthy environmental impact over the combined production of five metals (Farjana et al., 2019d)

Table 7

Summary of the findings and recommendations for LCA of gold mining.

\begin{tabular}{|c|c|c|}
\hline Study reference & Key findings & Recommendation \\
\hline $\begin{array}{l}\text { LCA on gold mining in } \\
\text { Australia (Norgate and } \\
\text { Haque, 2012) }\end{array}$ & $\begin{array}{l}\text { The refractory ore of gold has the } \\
\text { highest impact on mining and } \\
\text { comminution stage due to electricity } \\
\text { consumption. }\end{array}$ & $\begin{array}{l}\text { Gold mining technological } \\
\text { improvements would be } \\
\text { beneficial for high pressure gas } \\
\text { recovery, leaching, flotation } \\
\text { technologies, gravitational } \\
\text { technologies, etc. to reduce the } \\
\text { environmental impacts. }\end{array}$ \\
\hline $\begin{array}{l}\text { LCA of gold mining in } \\
\text { China (Chen et al., 2018) }\end{array}$ & $\begin{array}{l}\text { The largest impact is on the metal } \\
\text { depletion category from mining due to } \\
\text { energy consumption and emissions. } \\
\text { For climate change, electricity and } \\
\text { diesel were the largest contributors. }\end{array}$ & $\begin{array}{l}\text { Environmental policy suggestions } \\
\text { like increasing the resources } \\
\text { efficiency, adjusting energy } \\
\text { structure, gold recycling, and } \\
\text { ecological compensation approach } \\
\text { would be beneficial for reducing } \\
\text { impacts. }\end{array}$ \\
\hline $\begin{array}{l}\text { LCA of gold mining in } \\
\text { Australia (Haque and } \\
\text { Norgate, 2014) }\end{array}$ & $\begin{array}{l}\text { For gold mining, activities relating } \\
\text { well field impacts mostly about } 39 \% \\
\text { of total GHG, where } 56 \% \text { was from } \\
\text { gold extraction and metal production, }\end{array}$ & $\begin{array}{l}\text { Electricity generated from the } \\
\text { renewable energy resources such } \\
\text { as solar energy will beneficial for } \\
\text { reducing impacts from in-situ }\end{array}$ \\
\hline
\end{tabular}




\begin{tabular}{|c|c|c|}
\hline & and $5 \%$ were due to chemical use. & leaching. \\
\hline $\begin{array}{l}\text { LCA of gold-silver-lead- } \\
\text { zinc-copper beneficiation } \\
\text { (Farjana et al., 2019b) }\end{array}$ & $\begin{array}{l}\text { Gold-silver beneficiation has highest } \\
\text { impact over the other metals }\end{array}$ & $\begin{array}{l}\text { Modification in the electricity grid } \\
\text { mix to enhance the energy } \\
\text { efficiency will be helpful to } \\
\text { reduce environmental burdens. }\end{array}$ \\
\hline gold-silver & Gold refining from the gold-silver & Altering the material alloying \\
\hline refining operations & couple production have & properties for stainless steel \\
\hline (Farjana et al., 2019d) & $\begin{array}{l}\text { significantnotable environmental } \\
\text { impact over the combined production. }\end{array}$ & $\begin{array}{l}\text { would be beneficial to reduce } \\
\text { environmental impacts. }\end{array}$ \\
\hline
\end{tabular}

\subsection{LCA in iron mining}

Iron is one of the most abundant elements found in the earth's crust and is mostly widely used metal in modern civilization. Iron is used for making weapons and tools. The major miners and producers of iron are China, Australia, Brazil, Russia, and India. Iron can be mined from open pit mining or underground mining. Iron ore is extraction through drilling, blasting, excavating, loading, haulage, ore dumping, crushing, and screening. After screening lumped ores are sent through stacking, reclaiming, loading, transport. If the iron ores are fine ore then after screening it goes through stacking, reclaiming, loading, transport, pelleting and sintering. Table 8 describes the major findings and recommendations from the research conducted related to LCA of this metal.

Ferreira et al. analysed the iron production for an open pit mine located in Brazil. Dataset was collected from company reports. The functional unit considered was one tonne of iron ore concentration produced. The analysis was done using SimaPro software and IPCC method. They found that use of grinding media was the largest contributor to environmental emissions with the largest impact on human health and quality of ecosystems. Emission of inhalable inorganic materials is affecting human health. Greenhouse gas emissions are from electricity consumption which was $13.32 \mathrm{~kg} \mathrm{CO}_{2}$ eq for 1 ton of iron produced (Ferreira and Leite, 2015). Haque et al. analysed LCA of open pit iron ore mining and processing which comprises of drilling, blasting, loading, haulage, crushing, screening, separation, stacking, and stockpiling. The functional unit was 1 ton. The impact categories were gross energy requirements and GHG emissions. The analysis was done by Australian Indicator method. The analysis results showed that loading and haulage made the highest contribution to GHG (11.9 $\mathrm{CO}_{2}$ eq/t) (Haque and Norgate, 2015; Norgate and Haque, 2010). Gan et al. analysed LCA of mining and processing of iron ore mine in China. The iron mine considered consists of open pit mine and underground mine. The functional unit was 1 tonne of iron ore. The analysis was done using the IPCC method. They found that the highest GHG contribution is from agglomeration, loading, haulage, and ore processing, where mean value is $270 \mathrm{~kg} \mathrm{CO}_{2}$ eq tonne. The | second largest contributor is vegetation(Gan and Griffin, 2018).

Table 8

Summary of the findings and recommendations for LCA of iron mining.

\begin{tabular}{|l|l|l|}
\hline Study reference & Key findings & Recommendation \\
\hline $\begin{array}{l}\text { LCA of iron mining in } \\
\text { Brazil (Ferreira and Leite, } \\
\text { 2015) }\end{array}$ & $\begin{array}{l}\text { The use of grinding media was the } \\
\text { largest contributor to environmental } \\
\text { emissions with the largest impact on } \\
\text { human health and quality of } \\
\text { ecosystems. }\end{array}$ & $\begin{array}{l}\text { Replacement of fossil fuels with } \\
\text { biodiesel would be beneficial for } \\
\text { reducing climate change effects. }\end{array}$ \\
\hline $\begin{array}{l}\text { LCA of iron mining in } \\
\text { Australia (Haque and }\end{array}$ & $\begin{array}{l}\text { The loading and haulage made the } \\
\text { highest contribution to GHG. }\end{array}$ & $\begin{array}{l}\text { Emerging technologies should be } \\
\text { adopted to reduce the } \\
\text { environmental burdens from } \\
\text { loading and hauling of iron ore. }\end{array}$ \\
\hline
\end{tabular}




\begin{tabular}{|l|l|l|}
\hline $\begin{array}{l}\text { LCA of iron mining in } \\
\text { China (Gan and Griffin, } \\
\text { 2018) }\end{array}$ & $\begin{array}{l}\text { The highest GHG contribution is from } \\
\text { agglomeration, loading, haulage, and } \\
\text { ore processing }\end{array}$ & $\begin{array}{l}\text { To reduce the environmental } \\
\text { impacts of iron mining in China, } \\
\text { high grade ore import from } \\
\text { abroad }\end{array}$ \\
\hline
\end{tabular}

\subsection{LCA in nickel mining}

Nickel is an important element for the military, marine, transport, aerospace, and architectural applications. In the nickel mining, the ore can be extracted from sulfidic ore or oxidic ore. If the ore is sulfidic, then it goes through beneficiation, pyrometallurgical extraction, refining. If the ore is oxidic, then it goes through ore preparation, hydrometallurgical extraction, and refining. Table 9 describes the major findings and recommendations from the research conducted related to LCA of this metal.

Khoo et al. studied three cradle-to-gate based nickel laterite technologies. The geographic region considered were Western Australia and Indonesia. The analysis was conducted using IMPACT 2002+ method, ReCiPe method, and Australian Indicator method. They were high-pressure acid leaching (HPAL), ferronickel, and direct nickel (DNi) process. Their study revealed that the highest environmental impact was from ferronickel, while the most sustainable was HPAL. It was also found that results obtained from Australian Indicator method were slightly higher than for other methods. Global warming potential was mostly contributed by fuel consumption in nickel reduction and smelting. Another major factor for GHG was coal consumption to produce steam (Khoo et al., 2017). Mistry et al. conducted LCA of nickel and ferronickel production. Their datasets were originated from nine companies, which comprised of 52\% global nickel production and $40 \%$ global ferronickel production. The analysis was done using Gabi software and CML 2001 method. They showed that extraction and refining steps were the major contributor for PED and GWP (Mistry et al., 2016).

Table 9

Summary of the findings and recommendations for LCA of nickel mining.

\begin{tabular}{|l|l|l|}
\hline Study reference & Key findings & Recommendation \\
\hline $\begin{array}{l}\text { LCA of nickel mining for } \\
\text { Australia and Indonesia } \\
\text { (Khoo et al., 2017) }\end{array}$ & $\begin{array}{l}\text { The highest environmental impact was } \\
\text { from ferronickel, while the most } \\
\text { sustainable was HPAL due to fuel } \\
\text { consumption in nickel reduction and } \\
\text { smelting. }\end{array}$ & $\begin{array}{l}\text { Nickel production using the DNi } \\
\text { method would be beneficial over } \\
\text { the HPAL method to enhance } \\
\text { sustainability. }\end{array}$ \\
\hline $\begin{array}{l}\text { LCA of global nickel } \\
\text { production (Mistry et al., } \\
\text { 2016) }\end{array}$ & $\begin{array}{l}\text { The extraction and refining steps were } \\
\text { the major contributor for PED and } \\
\text { GWP. }\end{array}$ & $\begin{array}{l}\text { The nickel institute will update } \\
\text { their life cycle inventory datasets } \\
\text { based on technological } \\
\text { advancements, energy efficiency, } \\
\text { and raw material inputs. }\end{array}$ \\
\hline
\end{tabular}

\subsection{LCA in rare earth elements mining}

These group of metals contains fifteen types of elements, which can exist in the form of oxide minerals. These rare earth elements are used for making optical and electronics products. Different industrial sectors are using these rare earth elements metallurgy, oil, and agriculture. They are mined from China, Brazil, and the United States. Rare earth elements can be mined using open pit mining or underground mining. After mining, it goes through beneficiation stage, which involves crushing and grinding, magnetic separation, multi-stage flotation, filtering, washing, and conditioning. At the refining stage, the concentrated rare earth elements go through leaching, roasting, co-products separation, ion exchange, 
calcination, solvent extraction, mixed concentration, mischmetal refining, water leaching, multistage acid leaching, precipitation, and acid digestion. Table 10 describes the major findings and recommendations from the research conducted related to LCA of this metal.

Weng et al. conducted LCA of rare earth elements, based on cradle-to-gate 26 mining projects. Their focus was on GER (Gross Energy Requirements) and GWP. The analysis was done using SimaPro software, ReCiPe method, and CED method. The allocation method was an economy-based allocation of SimaPro. They found that the greatest environmental impacts were from ionic clay, monazite, bastnaesite where the impact is higher than for most common metals like bauxite, copper, and steel (Weng et al., 2016). Lima et al. analysed LCA of $4 \mathrm{~kg}$ of rare earth element with $2 \mathrm{~kg}$ of coproducts from a Brazilian ore. The analysis was done using the IMPACT 2002+ method where the datasets were from CETEM. Their study showed that largest consumption of hydrochloric acid and ammonium oxides produce radioactive emissions which impact on ozone depletion potential, and carcinogens thus impact on human health (Lima et al., 2018).

Table 10

Summary of the findings and recommendations for LCA of rare earth elements mining.

\begin{tabular}{|l|l|l|}
\hline Study reference & Key findings & Recommendation \\
\hline $\begin{array}{l}\text { LCA of rare earth } \\
\text { elements (Weng et al., } \\
\text { 2016) }\end{array}$ & $\begin{array}{l}\text { The greatest environmental impacts } \\
\text { were from ionic clay, monazite, } \\
\text { bastnaesite where the impact is higher } \\
\text { than for most common metals like } \\
\text { bauxite, copper, and steel. }\end{array}$ & $\begin{array}{l}\text { Rare earth elements refining } \\
\text { technologies should adopt cleaner } \\
\text { ways based on mineralogy and } \\
\text { geological conditions. }\end{array}$ \\
\hline $\begin{array}{l}\text { LCA of rare earth } \\
\text { elements in Brazil (Lima } \\
\text { et al., 2018) }\end{array}$ & $\begin{array}{l}\text { The largest consumption of } \\
\text { hydrochloric acid and ammonium } \\
\text { oxides produce radioactive emissions } \\
\text { which impact on ozone depletion } \\
\text { potential, and carcinogens thus impact } \\
\text { on human health }\end{array}$ & $\begin{array}{l}\text { More investment is required in the } \\
\text { life cycle assessment sectors to } \\
\text { impact analysis. }\end{array}$ \\
\hline
\end{tabular}

\subsection{LCA in stainless steel miningproduction}

Steel industry is like oil and gas. Steel is widely used in construction works, transportation, packaging, and energy sector. China is one of the leading producers of steel. Steel is produced after processing in coke ovens, a sintering plant, blast furnace, and converter. Table 11 describes the major findings and recommendations from the research conducted related to LCA of this metal.

Norgate et al. conducted the LCA study of steel production where the functional unit was $1 \mathrm{~kg}$ of refined stainless steel. They assessed GWP, AP, and TED. The effects of different sources of electricity were also assessed. They used CSIRO software LCA-PRO for analysis. Their study revealed that when ferronickel was the nickel source, total energy consumption was higher than the case where nickel metal was used as a source. They also stated that nickel has the highest impact, then ferronickel, ferrochrome, and iron. While analysing the source of electricity, natural gas use could reduce the GWP without changing the total energy consumption, while hydroelectricity could reduce both (Norgate et al., 2007). Korol et al. assessed the cradle-to-grave LCA of steel production and arc furnace routes of Poland. They used SimaPro software and EcoInvent database for their analysis. The analysis method was IPCC, ReCipe, and CED. They showed that production of pig iron had the highest impact on GHG and fuel consumption due to electricity. They also showed that the iron ore sintering process was the highest contributor to dust and on GHG emissions. Direct GHG emissions were related to the combustion sources, while the indirect 
emissions were from fossils. The GHG value was $913 \mathrm{~kg} \mathrm{CO}_{2} \mathrm{eq} / \mathrm{FU}$ for natural electric arc furnace and $744 \mathrm{CO}_{2} \mathrm{eq} / \mathrm{FU}$ for crude steel (Burchart-Korol, 2013). Renzulli et al. studied cradle-to-gate LCA of an integrated steel mill in Italy. The system boundary was raw material extraction, the sintering operations, the coke production, and iron-steel production. The analysis method was ILCD while both mass and economy-based allocation were considered. Their results are similar like for Korol et al. that the most impactful processes were blast furnace and coke oven operations. More than $40 \%$ of the climate change, ozone depletion, and particulate matter were due to raw material transportation in the blast furnace and coke oven (Renzulli et al., 2016). Ma et al. analysed the crude steel production in China. Their functional unit was 1 ton of steel billet. The analysis method was IMPACT world+ model, IPCC, and ReCiPe. The system boundary includes mining, magnesium oxide production, transportation, and electricity generation. They analysed the water footprint caused by steel production and found that grey water footprint was higher than blue water footprint, while direct emissions played the key role for grey water footprint. Metal depletion was higher due to iron ore consumption (Ma et al., 2018).

\section{Table 11}

Summary of the findings and recommendations for LCA of steel mining.

\begin{tabular}{|c|c|c|}
\hline Study reference & Key findings & Recommendation \\
\hline $\begin{array}{l}\text { LCA of steel (Norgate et } \\
\text { al., 2007) }\end{array}$ & $\begin{array}{l}\text { Stated that when ferronickel was the } \\
\text { nickel source, total energy } \\
\text { consumption was higher than the case } \\
\text { where nickel metal was used as a } \\
\text { source. They also stated that nickel has } \\
\text { the highest impact, then ferronickel, } \\
\text { ferrochrome, and iron. }\end{array}$ & $\begin{array}{l}\text { Alternative metal production } \\
\text { technologies should be developed } \\
\text { to reduce the environmental } \\
\text { burdens. }\end{array}$ \\
\hline $\begin{array}{l}\text { LCA of steel production } \\
\text { in Poland (Burchart- } \\
\text { Korol, 2013) }\end{array}$ & $\begin{array}{l}\text { The production of pig iron had the } \\
\text { highest impact on GHG and fuel } \\
\text { consumption due to electricity. They } \\
\text { also showed that the iron ore sintering } \\
\text { process was the highest contributor to } \\
\text { dust and on GHG emissions }\end{array}$ & $\begin{array}{l}\text { In future, LCA of alternative steel } \\
\text { production technologies should be } \\
\text { conducted including } \\
\text { thermodynamic analysis and } \\
\text { exergy analysis. }\end{array}$ \\
\hline $\begin{array}{l}\text { LCA of steel mill in Italy } \\
\text { (Renzulli et al., 2016) }\end{array}$ & $\begin{array}{l}\text { The most impactful processes were } \\
\text { blast furnace and coke oven } \\
\text { operations. More than } 40 \% \text { of the } \\
\text { climate change, ozone depletion, and } \\
\text { particulate matter were due to raw } \\
\text { material transportation in the blast } \\
\text { furnace and coke oven }\end{array}$ & $\begin{array}{l}\text { Energy and fuel exchange } \\
\text { between the power plants and } \\
\text { factory can be modelled and } \\
\text { analysed. LCA analysis can also } \\
\text { be extended based on steel } \\
\text { product rolling operations. }\end{array}$ \\
\hline $\begin{array}{l}\text { LCA of steel production } \\
\text { in China (Ma et al., 2018) }\end{array}$ & $\begin{array}{l}\text { The water footprint caused by steel } \\
\text { production and found that grey water } \\
\text { footprint was higher than blue water } \\
\text { footprint, while direct emissions } \\
\text { played the key role for grey water } \\
\text { footprint }\end{array}$ & $\begin{array}{l}\text { Further studies should be carried } \\
\text { out based on dynamic database } \\
\text { and spatial disparity in water } \\
\text { footprint evaluation in different } \\
\text { aspects. }\end{array}$ \\
\hline
\end{tabular}

\subsection{LCA in uranium mining}

Uranium is the source of nuclear power which is widely produced and naturally found. Nuclear power accounts for more than $10 \%$ of power production in the world. The uranium deposits are mostly found in Australia, Kazakhstan, and Canada. Uranium can be mined using open pit mining or underground mining. 
The mined ores are then going through crushing, grinding, leaching, solid separation, liquor extraction, uranium precipitation, solid separation, and drying. Table 12 describes the major findings and recommendations from the research conducted related to LCA of this metal.

Norgate et al. studied the LCA of nuclear power production for uranium while the ore grade was $0.15 \%$ $\mathrm{U}_{3} \mathrm{O}_{8}$. The functional unit was $1 \mathrm{MWh}$ of electricity produced from $1 \mathrm{GWe}$ nuclear reactor. The system boundary includes uranium ore mining to electricity production in a plant. Their study found that fuel enrichment stage made the highest contribution of GHG while the total GHG was $34 \mathrm{~kg} \mathrm{CO}$ eq/MWh. But if the ore grade falls to $0.01 \%$, then the GHG would be $60 \mathrm{~kg} \mathrm{CO}$ eq/MWh (Haque and Norgate, 2014; Norgate et al., 2014). Parker et al. studied the cradle-to-gate uranium mining and milling in Canada. They found that source of GHG, that is the energy used to produce electricity and process emissions from non-energy resources was the largest contributor to environmental emissions (Parker et al., 2016). Farjana et al. analysed and compared among open pit mining, underground mining, and in-situ leaching uranium mining operations. They found that in-situ leaching has a higher impact on all the environmental impact categories except ionising radiation. On the other hand, underground mining effects adversely on ionising radiation (S.H. Farjana et al., 2018a; Shahjadi Hisan Farjana et al., 2018b). Haque et al. conducted a comparative LCA study among in-situ leaching based production of copper, gold, and uranium. Their study was conducted based on Australian Impact method using SimaPro software. They showed that for uranium mining, well field related activities and chemical consumption contributed the most for GHG. Chemical consumption for leaching and mineral processing contributed about $20 \%$ of GHG, while wellfield related electricity consumption emits $74 \%$ of GHG (Haque and Norgate, 2014).

Table 12

Summary of the findings and recommendations for LCA of uranium mining.

\begin{tabular}{|l|l|l|}
\hline Study reference & Key findings & Recommendation \\
\hline $\begin{array}{l}\text { LCA of nuclear power } \\
\text { production (Norgate et } \\
\text { al., 2014) }\end{array}$ & $\begin{array}{l}\text { The fuel enrichment stage made the } \\
\text { highest contribution of GHG }\end{array}$ & $\begin{array}{l}\text { New technologies in different } \\
\text { stages of nuclear fuel cycle would } \\
\text { beneficial for reducing } \\
\text { environmental burdens. }\end{array}$ \\
\hline $\begin{array}{l}\text { LCA of uranium mining } \\
\text { in Canada (Parker et al., } \\
\text { 2016) }\end{array}$ & $\begin{array}{l}\text { The energy used to produce electricity } \\
\text { and process emissions from non- } \\
\text { energy resources was the largest } \\
\text { contributor to environmental emissions }\end{array}$ & $\begin{array}{l}\text { In future, detailed LCA study } \\
\text { covering all the environmental } \\
\text { impact categories should be } \\
\text { conducted to reduce the } \\
\text { environmental burdens and to } \\
\text { trade off among the competing } \\
\text { energy products. }\end{array}$ \\
\hline $\begin{array}{l}\text { LCA of global uranium } \\
\text { mining (S.H. Farjana et } \\
\text { al., 2018a; Shahjadi } \\
\text { Hisan Farjana et al., } \\
\text { 2018b) }\end{array}$ & $\begin{array}{l}\text { The in-situ leaching has a higher } \\
\text { categories except ionising radiation }\end{array}$ & $\begin{array}{l}\text { In future, further studies should be } \\
\text { conducted using the natural gas- } \\
\text { based scenario for process and } \\
\text { mine specific datasets. }\end{array}$ \\
\hline $\begin{array}{l}\text { LCA of uranium mining } \\
\text { in Australia (Haque and } \\
\text { Norgate, 2014) }\end{array}$ & $\begin{array}{l}\text { The well field related activities and } \\
\text { chemical consumption contributed the } \\
\text { most for GHG }\end{array}$ & $\begin{array}{l}\text { Electricity generated from the } \\
\text { renewable energy resources such } \\
\text { as solar energy will beneficial for } \\
\text { reducing impacts from in-situ } \\
\text { leaching. }\end{array}$ \\
\hline
\end{tabular}

\subsection{LCA in zinc mining}


Zinc is used for the galvanising process, to protect steel in the construction, transportation, and products. ZineIt is also used as an alloying element with copper. But they are mainly used with iron and steel.Zinc is produced from ore mining, mineral processing, concentration, roasting, leaching, purification, and electrolysis. Table 13 describes the major findings and recommendations from the research conducted related to LCA of this metal.

Genderen et al. analysed the cradle-to-gate LCA of zinc concentrate and special high-grade zinc. Their geographical coverage considered in that study was global. The system boundary consists of zinc ore mining, concentration, transportation, and smelting. Datasets were collected from 24 mines and 18 smelters and analysed using Gabi software. The selected impact categories were GWP, AP, EU (Eutrophication), POCP, ODP, and PED. The analysis was done using the CML method, and the functional unit was 1 MT (Mega tonne) of zinc. Their study found that the impacts of zinc production were primarily due to energy consumption in the mining and concentration process. Electricity consumption was huge, which the country and grid mix played a significant role (Van Genderen et al., 2016). Qi et al. conducted LCA of hydrometallurgical zinc production in China which was based on National inventory datasets. The analysis was done by ReCiPe method, and the functional unit was 1 tonne of hydrometallurgical zinc production. Their study reveals that overall environmental emissions were due to zinc ore mining and energy consumption in the form of electricity and natural gas. They also stated that pollutants like copper, zinc, lead, which were emitted to the environment were responsible for human toxicity, marine aquatic ecotoxicity. Carbon-di-oxide emission from coal-based electricity generation was dominant for climate change and fossil depletion. Also, the heavy metals from iron ore mining and refining contributed to impacts on human health and water (Qi et al., 2017). Farjana et al. analyzed the gold-silver-lead-zinc-copper beneficiation process, which summarizes that gold-silver beneficiation has greatest impact over the other metal in these joint production which is due to the electricity usage through fossil fuel consumption (Farjana et al., 2019b).

Table 13

Summary of the findings and recommendations for LCA of zinc mining.

\begin{tabular}{|l|l|l|}
\hline Study reference & Key findings & Recommendation \\
\hline $\begin{array}{l}\text { LCA of global zinc } \\
\text { production } \begin{array}{l}\text { (Van } \\
\text { Genderen et al., 2016) }\end{array}\end{array}$ & $\begin{array}{l}\text { The impacts of zinc production were } \\
\text { in the mining and concentration } \\
\text { process. }\end{array}$ & $\begin{array}{l}\text { In future, including the unit } \\
\text { process details for LCA analysis } \\
\text { for concentration and smelting } \\
\text { would be beneficial for } \\
\text { sustainability. }\end{array}$ \\
\hline $\begin{array}{l}\text { LCA of zinc production } \\
\text { in China (Qi et al., 2017) }\end{array}$ & $\begin{array}{l}\text { The overall environmental emissions } \\
\text { were due to zinc ore mining and } \\
\text { energy consumption in the form of } \\
\text { electricity and natural gas. }\end{array}$ & $\begin{array}{l}\text { In future, their study would be } \\
\text { beneficial to build national LCI } \\
\text { database for zinc production in } \\
\text { China. }\end{array}$ \\
\hline $\begin{array}{l}\text { LCA of gold-silver-lead- } \\
\text { zinc-copper beneficiation } \\
\text { (Farjana et al., 2019b) }\end{array}$ & $\begin{array}{l}\text { Gold-silver beneficiation has highest } \\
\text { impact over the other metals }\end{array}$ & $\begin{array}{l}\text { Modification in the electricity grid } \\
\text { mix to enhance the energy } \\
\text { efficiency will be helpful to } \\
\text { reduce environmental burdens. }\end{array}$ \\
\hline
\end{tabular}

\subsection{Other metals and their LCA studies}

Table 14 describes the major findings and recommendations from the research conducted related to LCA of these metals. 
Cobalt is a valuable metal found in the earth's crust which is widely used in the industrial applications. Cobalt mining has notable impact on human health due to cancer-causing elements which may cause heart disease, vision problem, etc. Farjana et al. conducted the eomplete-life cycle assessment of cobalt extraction process. According to their study, cobalt extraction is harmful for eutrophication and global warming. Cobalt extraction requires hugelarge amount of electricity which is detrimental for global warming, and also is the blasting.

Cemented carbide has higher hardness and higher corrosion resistance, mostly. They are-used for drilling tools and cutting tools. China is the leading producer of cemented carbide. The cemented carbide ore is mined from extraction, crushing, milling, gravity method grinding, sulphide flotation, and roasting. In the hydro-metallurgy stage, the cemented carbide ore is digested, filtrated, precipitated, extracted using solvent, and finally crystalised. In the pyrometallurgy stage, the ore goes through calcination, hydrogen reduction, and carburization. In the powder metallurgy stage, the ore goes through powder milling, granulation, and sintering. Furberg et al. conducted a cradle to gate LCA of cemented carbide production with cobalt, while the geographic location was non-Chinese (Canada and USA). Their study stated that impacts were due to elements like kerosene, tailings, water, and electricity. The highest impacts were on the category of TAP (terrestrial acidification), ODP (ozone depletion), FEU (freshwater eutrophication). And the lowest impact was on CC (climate change), PCOF (photochemical oxidant formation), and WD (water depletion) (Furberg et al., 2019).

Manganese is an essential element for batteries, fertilisers, and chemicals. Manganese is a widely used alloying element comes in conjunction to make ferroalloys. The manganese alloy is produced using mineral extraction, hauling, ore preparation and beneficiation, sintering and transportation, smelting, crushing, screening, and refining. Westfall et al. conducted an LCA study based on manganese alloys, where datasets were collected from 16 ore and alloy producers. The authors $y$ have conducted a cradle-togate LCA of silicomanganese, ferromanganese, and refined ferromanganese. The impact categories considered were GWP, AP, POCP, water, and waste. The analysis was done using CML 2001 method. According to their analysis, electricity demand, fuel consumption during smelting were the primary contributors for impact (Westfall et al., 2016).

Magnesium oxide cement are widely produced in China, North Korea, Turkey, Russia, and Australia. The magnesium oxide is produced from the raw material acquisition, crushing, vertical shaft kiln, precipitation tank, screening, crushing, grinding, and packaging. If it is Portland cement, then after crushing it goes through preheating, rotary kiln, cooling zone, crushing, grinding, and packaging. Ruan et al. analysed the LCA of magnesium oxide where the functional unit was 1 tonne. They showed that $\mathrm{MgO}$ has a lower impact on ecosystem and resources but larger impact on human health. The analysis was done using EcoIndicator 99 method. They considered five different case scenarios based on fossil fuel and raw material consumption (Ruan and Unluer, 2016).

Silver metal is most widely used for industrial purposes or for making jewelries. There are very few studies which addressed the environmental impact of silver mining processes. Farjana et al. analysed the environmental burdens associated with gold-silver-lead-zinc-copper beneficiation process (Farjana et al., 2019b). In another study, they analysed the environmental impacts of gold-silver refining operations (Farjana et al., 2019d). They found that silver beneficiation and refining have least environmental impacts than gold mining processes as they consume least amount of electricity, Hhowever, there are some impacts in the eategories where they have impact are eutrophication, global warming, and ecotoxicity (Farjana et al., 2019b, 2019d).

Titanium oxides are widely used for making high-performance metal parts, artificial body parts, and engine elements. Ilmenite and rutile are the generally found form of titanium oxides. Ilmenite and rutile are extracted from mine site using heavy mineral concentration, rare earth drum separation, electrostatic 
separation circuit, and gravity separation circuit. Farjana et al. conducted a comparative LCA analysis of cradle-to-gate titanium oxides production. Ilmenite and rutile were considered where the geographic region considered was for Australia. The datasets were collected from AusLCI database and SimaPro software. The study revealed that rutile had a significant environmental impact than for ilmenite due to higher energy consumption and electricity use. The GHG was $0.295 \mathrm{~kg} \mathrm{CO}_{2} \mathrm{eq} / \mathrm{kg}$ of ilmenite production and $1.535 \mathrm{~kg} \mathrm{CO}_{2} \mathrm{eq} / \mathrm{kg}$ of rutile production (Shahjadi Hisan Farjana et al., 2018a).

Table 14

Summary of the findings and recommendations for LCA of different metals minings.

\begin{tabular}{|c|c|c|}
\hline Study reference & Key findings & Recommendation \\
\hline $\begin{array}{l}\text { LCA of cobalt extraction } \\
\text { process (Farjana et al., } \\
2019 \mathrm{c})\end{array}$ & $\begin{array}{l}\text { Eutrophication and global warming } \\
\text { impacts are higher due to electricity } \\
\text { consumption }\end{array}$ & $\begin{array}{l}\text { Altering the electricity generation } \\
\text { resources within the same grid } \\
\text { mix network will be beneficial for } \\
\text { sustainability. }\end{array}$ \\
\hline $\begin{array}{lr}\text { LCA of } & \text { non-Chinese } \\
\text { cemented } & \text { carbide } \\
\text { production } & \text { (Furberg et } \\
\text { al., 2019) } & \\
\end{array}$ & $\begin{array}{l}\text { The impacts were due to elements like } \\
\text { kerosene, tailings, water, and } \\
\text { electricity. }\end{array}$ & $\begin{array}{l}\text { In future, improvement in LCI } \\
\text { datasets is required to get rid of } \\
\text { uncertainty in environmental } \\
\text { sustainability. }\end{array}$ \\
\hline 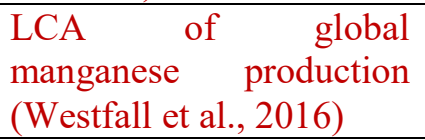 & $\begin{array}{l}\text { The electricity demand, fuel } \\
\text { consumption during smelting were the } \\
\text { primary contributors for impact. }\end{array}$ & $\begin{array}{l}\text { In future, the LCI datasets and } \\
\text { LCA results can be integrated to }\end{array}$ \\
\hline $\begin{array}{l}\text { LCA of magnesium oxide } \\
\text { production (Ruan and } \\
\text { Unluer, 2016) }\end{array}$ & $\begin{array}{l}\mathrm{MgO} \text { has a lower impact on ecosystem } \\
\text { and resources but larger impact on } \\
\text { human health }\end{array}$ & $\begin{array}{l}\text { An extensive database with } \\
\text { detailed LCI should be built to } \\
\text { conduct detailed LCA analysis. } \\
\text { Moreover, reduction of carbon } \\
\text { dioxide emissions should be } \\
\text { achieved. }\end{array}$ \\
\hline $\begin{array}{l}\text { LCA of titanium oxides } \\
\text { in Australia (Shahjadi } \\
\text { Hisan Farjana et al., } \\
\text { 2018a) }\end{array}$ & $\begin{array}{l}\text { Rutile had a significant environmental } \\
\text { impact than for ilmenite due to higher } \\
\text { energy consumption and electricity } \\
\text { use. }\end{array}$ & $\begin{array}{l}\text { Electricity grid mix have } \\
\text { significant impact on the } \\
\text { environmental impact analysis } \\
\text { results which would be analysed } \\
\text { extensively in future. }\end{array}$ \\
\hline $\begin{array}{l}\text { LCA of gold-silver-lead- } \\
\text { zinc-copper beneficiation } \\
\text { (Farjana et al., 2019b) }\end{array}$ & $\begin{array}{l}\text { Gold-silver beneficiation has highest } \\
\text { impact over the other metals }\end{array}$ & $\begin{array}{l}\text { Modification in the electricity grid } \\
\text { mix to enhance the energy } \\
\text { efficiency will be helpful to } \\
\text { reduce environmental burdens. }\end{array}$ \\
\hline $\begin{array}{ll}\text { LCA of } & \text { gold-silver } \\
\text { refining } & \text { operations } \\
\text { (Farjana et al., } 2019 \mathrm{~d})\end{array}$ & $\begin{array}{l}\text { Gold-silver refining from the couple } \\
\text { production of gold-silver have more } \\
\text { environmental burdens associated with } \\
\text { gold-silver-lead-zinc-copper couple } \\
\text { production. }\end{array}$ & $\begin{array}{l}\text { Altering the stainless steel } \\
\text { alloying properties would be } \\
\text { beneficial for sustainability. }\end{array}$ \\
\hline
\end{tabular}

\section{Discussion}


This chapter discusses the key aspects of the research articles on life cycle assessment of metal and mining industries. Analysis results ef life cycle assessment in mining industries-can be discussed based on a combination of three different perspectives _ . The perspective based on mining technologies, based on environmental impacts, and based on energy consumption and integration. According to the discussion on the LCA results presented in table 15, which describes the key findings of these research papers on LCA based on metal type, it is quite evident that the common reason for largest environmental impact from mining is due to energy generation, fossil fuel consumption for energy and process heat generation. For aluminium, smelting and refining stage made the greatest contribution due to energy consumption and direct emissions to the environment. From the cemented carbide production, the mining, hydrometallurgy, and powder metallurgy stages made the greatest contribution due to kerosene use, sulfidic tailing, water, and electricity. In the case of coal mining, still electricity use, fossil fuel use for heat generation creates greater environmental impacts generated from the mining stage. Among the copper mining steps, solvent extraction and electrowinning in hydrometallurgy causes greater environmental impact rather than for pyrometallurgy, due to electricity, fossil fuel use for heat generation, and steel use. Gold mining is impactful in mining and comminution stage, due to well field related activities. Agglomeration, loading, haulage, and ore processing in iron mining is harmful to the environment due to the emission of inorganic chemical materials, use of electricity, and use of grinding media. From magnesium oxide production, calcination stage is highly impactful towards environment due to fossil fuel usage in the form of coal. For nickel production, primary extraction, nickel reduction, and smelting are impactful due to electricity usage and coal consumption to produce steam. The oxide separation stage in rare earth mining step, consume a huge amount of hydrochloric acid and ammonium oxides which is harmful. Pig iron in a blast furnace and iron ore sintering process in steel and stainless-steel production causes greater impact due to electricity and fossil fuel usage. The fuel enrichment stage, well-field related stages, and the mining stage cause the greatest environmental impact of uranium mining due to electricity usage, use of chemicals and indirect emissions. In summary, mining and extraction stages made the greatest contribution in cemented carbide, coal, gold, titanium oxides, and zinc production. Smelting and refining steps cause a higher impact for aluminium, ferroalloy, nickel, and manganese mining which are due to significant amount of electricity consumed in smelting operation.

From the discussion presented above and in table 15 , it is quite evident that most of the environmental emissions from mining industries are due to electricity consumption and fossil fuel usage, whatever the process is. Fossil fuel can be of the form of diesel oil, natural gas, heavy fuel oil, and residual fuel oi. These fossil fuels can be used for electricity production, process heat generation, and mechanical energy generation. Among these, fossil fuel use can be reduced or replaced by integrating renewable energy resources. Renewable energy can be used as an alternative fuel to generate electricity or to produce process heat. Several LCA studies assessed the environmental impact scenario with the integration of renewable energy resources in mining industries. There could be replacement by different types of renewables either partially or completely. Another major reason is the electricity grid mix, which varies from one country to another. The grid mix is a combination of fuel sources used to generate electricity. Among the three major components in LCA, electricity mix, technology mix, and heat mix- electricity mix and heat mix both are related to fossil fuel. Between them, a most adverse effect is from electricity use which impacts on GWP and AP. It also affects PED and GER. Replacing coal with natural gas may also be a solution to reduce GWP with same GER, but natural gas has more ionising radiation impact on human health. However, it is possible but dependent on the availability of the renewables at the mining site to integrate with the power generation system. This replacement is time-consuming and involves huge capital cost. Another important point is electricity generation efficiencies which could be improved after involving modern technologies.

Another major part is the integration of renewable resources to generate process heat in mining. Regarding solar energy, temperatures below $150_{-}^{\circ}$ degree Celsius could easily be achieved by non-CST (non-concentrated solar thermal) technologies. Temperatures ranging between $150_{-}^{\circ}$ degree to $400_{-}^{\circ}$ degree 
Celsius is possible to generate with primary CST (concentrated solar thermal) technologies. There are few industries in the world where already process heat integration is operating with solar technologies. Few mines in Chile are utilising solar process heat for electrowinning operations. South Africa is using solar process heat for mining and cleaning operations. Cyprus, Austria, India, and Germany are also using solar process heat for different low-temperature mining operations which all operate below $100_{-}^{\circ}$ degree-Celsius. The availability of solar energy also varies depending on the latitude and longitude, irradiation, and many other factors. Not all miner countries could have this renewable source of energy.

Other than energy integration, there are some technological factors which affect the environmental impacts of mining processes - the most important factor, which was discussed in almost every paper that ore grade effects largely on environmental burdens associated with mining. The deeper would the mining goes; the greater machinery requirements and the energy consumption would be. The more we are approaching towards development, more mining of the metals is required. Another important factor is the use of inorganic chemicals for chemical extraction, acid leaching, and electrowinning processes; which is more troublesome for environmental sustainability. Mining tailing management is another critical issue, which causes significant load on environment impacting human health, ecosystems, and resources.

\section{Table 15}

Key factors of environmental impacts from metal mining industries.

\begin{tabular}{|c|c|c|}
\hline Metal & $\begin{array}{l}\text { Highest } \\
\text { Impactful } \\
\text { Category }\end{array}$ & Impactful process \\
\hline $\begin{array}{l}\text { Aluminium (Nunez } \\
\text { and Jones, 2016; } \\
\text { Paraskevas et al., } \\
\text { 2016; Tan and Khoo, } \\
\text { 2005) }\end{array}$ & $\begin{array}{l}\text { GWP due to } \\
\text { smelting } \\
\text { refining }\end{array}$ & $\begin{array}{l}\text { Smelting and refining, electricity consumption and direct } \\
\text { emissions. }\end{array}$ \\
\hline $\begin{array}{l}\text { Cobalt (Farjana et } \\
\text { al., 2019c) }\end{array}$ & $\underline{\mathrm{GWP}, \mathrm{EU}}$ & Extraction due to electricity consumption and blasting. \\
\hline $\begin{array}{l}\text { Cemented carbide } \\
\text { (Furberg et al., 2019) }\end{array}$ & TE, OD, FWE & $\begin{array}{l}\text { Mining, hydrometallurgy, and power metallurgy phases. } \\
\text { Due to kerosene, sulfidic tailing, water use, and electricity } \\
\text { use. }\end{array}$ \\
\hline $\begin{array}{l}\text { Coal (Adiansyah et } \\
\text { al., 2017; Burchart- } \\
\text { Korol et al., 2016; } \\
\text { Guimarães da Silva } \\
\text { et al., 2018; Zhang et } \\
\text { al., 2018) }\end{array}$ & Dust, GWP, AP & $\begin{array}{l}\text { Mining due to electricity usage, diesel oil consumption, } \\
\text { fossil fuel, use of steel and heat. }\end{array}$ \\
\hline $\begin{array}{l}\text { Copper (Ekman } \\
\text { Nilsson et al., 2017; } \\
\text { Haque and Norgate, } \\
\text { 2014; Memary et al., } \\
\text { 2012; Norgate, 2001; } \\
\text { Northey et al., 2013) }\end{array}$ & GWP & $\begin{array}{l}\text { Solvent extraction and electrowinning, leaching due to } \\
\text { electricity usage, fossil fuel, sulfuric acid. }\end{array}$ \\
\hline $\begin{array}{l}\text { Ferroalloy (Bartzas } \\
\text { and Komnitsas, } \\
\text { 2015; Haque and } \\
\text { Norgate, 2013) }\end{array}$ & GWP & Smelting and refining due to electricity usage, fossil fuel. \\
\hline Gold (Chen et al., & GWP, MD & Mining and comminution, well field related activities due \\
\hline
\end{tabular}




\begin{tabular}{|c|c|c|}
\hline $\begin{array}{l}\text { 2018; Farjana et al., } \\
\text { 2019b, 2019d; Haque } \\
\text { and Norgate, 2014; } \\
\text { Norgate and Haque, } \\
\text { 2012) }\end{array}$ & & $\begin{array}{l}\text { to electricity usage, diesel oil consumption, and direct } \\
\text { emissions. }\end{array}$ \\
\hline $\begin{array}{l}\text { Iron (Ferreira and } \\
\text { Leite, 2015; Gan and } \\
\text { Griffin, 2018; Haque } \\
\text { and Norgate, 2015; } \\
\text { Norgate and Haque, } \\
\text { 2010) }\end{array}$ & $\begin{array}{l}\text { GHG, human } \\
\text { health }\end{array}$ & $\begin{array}{l}\text { Agglomeration, loading and haulage, ore processing, } \\
\text { vegetation and soil removal due to electricity usage, } \\
\text { emission of inorganic materials, use of grinding media. }\end{array}$ \\
\hline $\begin{array}{l}\text { Manganese (Westfall } \\
\text { et al., 2016) }\end{array}$ & GHG & $\begin{array}{l}\text { Smelting due to electricity usage, fossil fuel (coal and } \\
\text { coke). }\end{array}$ \\
\hline $\begin{array}{l}\text { Magnesium oxide } \\
\text { (Ruan and Unluer, } \\
\text { 2016) }\end{array}$ & Human health & Calcination due to coal usage. \\
\hline $\begin{array}{l}\text { Nickel (Khoo et al., } \\
\text { 2017; Mistry et al., } \\
\text { 2016) }\end{array}$ & GHG & $\begin{array}{l}\text { Primary extraction, nickel reduction and smelting due to } \\
\text { electricity usage, coal consumption to produce steam. }\end{array}$ \\
\hline $\begin{array}{l}\text { Rare earth element } \\
\text { (Lima et al., 2018; } \\
\text { Zaimes et al., 2015) }\end{array}$ & ODP, carcinogens & $\begin{array}{l}\text { Oxide separation step due to consumption of hydrochloric } \\
\text { acid and ammonium oxides. }\end{array}$ \\
\hline$\frac{\text { Silver }}{2019 b, 2019 d)}$ & $\underline{\mathrm{GWP}, \mathrm{EU}}$ & $\begin{array}{l}\text { Stainless steel and electricity used in beneficiation and } \\
\text { refining processes. }\end{array}$ \\
\hline $\begin{array}{l}\text { Steel (Burchart- } \\
\text { Korol, 2013; Norgate } \\
\text { et al., 2007; Renzulli } \\
\text { et al., 2016) }\end{array}$ & GHG, dust & $\begin{array}{l}\text { Pig iron in the blast furnace and coke oven operations, the } \\
\text { iron ore sintering process due to electricity usage, fossil } \\
\text { fuel. }\end{array}$ \\
\hline $\begin{array}{lr}\text { Titanium } & \text { oxides } \\
(\text { Shahjadi } & \text { Hisan } \\
\text { Farjana et al., } & 2018 \mathrm{a}) \\
\end{array}$ & GHG & Mining due to electricity usage. \\
\hline $\begin{array}{l}\text { Uranium (Shahjadi } \\
\text { Hisan Farjana et al., } \\
\text { 2018b; Haque and } \\
\text { Norgate, 2014; } \\
\text { Norgate et al., 2014; } \\
\text { Parker et al., 2016) }\end{array}$ & GHG & $\begin{array}{l}\text { Fuel enrichment, well field related activities, leaching due } \\
\text { to electricity usage, use of chemicals, and direct } \\
\text { emissions. }\end{array}$ \\
\hline $\begin{array}{l}\text { Zinc (Qi et al., 2017; } \\
\text { Van Genderen et al., } \\
\text { 2016) }\end{array}$ & GWP & $\begin{array}{l}\text { Mining and concentration due to electricity consumption } \\
\text { and fossil fuel usage. }\end{array}$ \\
\hline
\end{tabular}

\section{Conclusion}

In conclusion, this review paper presents a comprehensive scenario of all the existing studies reported in the literature aims to analyse the existing literature on the life cycle environmental impact analysis of metal mining industries. Sixteen metal mining industries are identified which have the significant research output that quantified the environmental effects based on LCA methods. A comprehensive compilation of the published work is being carried out, analysed, compared the impactful mining materials, processes which are energy intensive, thus harmful for global environmental sustainability. According to the | findings presented in of this paper, mining and extraction stages made the notable greatest contribution in 
cemented carbide, coal, gold, titanium oxides, and zinc production. In addition, Also, smelting and refining steps cause a considerable amount of higher-impact for aluminium, ferroalloy, nickel, and manganese mining which are due to significant amount of electricity consumed in smelting operation. This paper also summarises the key methods of life cycle assessment which were utilised for mining industries. Limitations of these studies sustainability are also presented. The most important challenge is the replacement of energy generation resources by renewables, which could significantly reduce the gross energy requirements and global warming potential, to achieve the sustainability goals for 2050 .

In summary, there are some many-limitations, and future recommendations on their basis-focused on LCA techniques and methods as follows: which should be brought under the focus of attention of the scientific community for the betterment of the future environment. The key points are:

a. Development of global LCA method which would be applicable irrespective of the geographic region of the mining company.

b. Development of aggregated allocation technique for coproduction of metals, which would be free from technological and economic differences of metals.

c. Analysis of complete LCA for each metal industries, as most of them, lack full LCA study, due to the research focus and availability of dataset.

d. Development of specific database focused on mining industries life cycle inventory datasets, which should would contain inventory datasets for every type of mining technology per metal.

According to the analysis results presented in this study, it is evident that the mining industry is significantlyconsiderably affecting global warming potential and human health (carcinogenic and noncarcinogenic). The following measures could be adopted for significant reduction in the emission during the mining processes:

a. Replacement of electricity generation sources by renewables is of paramount importance. required. The choice of renewable energy resource would be dependent on the geographic location of the mine, availability of energy resources, and the capital cost of replacement.

b. Process heat generation sources could be altered by renewables. Mining processes should be classified as in terms of heating needs as low-temperature, medium temperature, and hightemperature process heat applications. Following that, the feasibility of process heat integration should be assessed approaching towards the practical integration.

c. Sourcing high grade Increasing the-mining ore grade-would be beneficial for the environment, which will consume less energy in the form of electricity and heat and less equipment to extract mined ore. Increasing the ore grade would also decrease the chance of acid rain.

d. Decreasing the use of inorganic chemicals for leaching or increasing the efficiency of leaching processes would be beneficial to reduce the human health impacts, both carcinogenic and noncarcinogenic.

\section{Nomenclature}

\begin{tabular}{|l|l|}
\hline Term & Description \\
\hline AP & Acidification \\
\hline CC & Climate change \\
\hline CED & Cumulative energy demand \\
\hline CETEM & Center for mineral technology database \\
\hline
\end{tabular}




\begin{tabular}{|l|l|}
\hline CSIRO & Commonwealth Scientific and Industrial Research Organization \\
\hline CML & Center for methodological development \\
\hline CST & Concentrated solar thermal technology \\
\hline DNi & Direct Nickel method \\
\hline EDIP & Environmental Design of Industrial Products \\
\hline EU & Eutrophication \\
\hline FEU & Freshwater eutrophication \\
\hline FFD & Fossil fuel depletion \\
\hline FWE & Freshwater ecotoxicity \\
\hline GER & Gross energy requirements \\
\hline GWP & Global warming potential \\
\hline HH & Human health \\
\hline HPAL & High pressure acid leaching \\
\hline HT & Human toxicity \\
\hline IAI & International Aluminum Institute \\
\hline IPCC & Intergovernmental Panel on Climate Change \\
\hline ILCD & International Reference Life Cycle Data System \\
\hline ISO & International Organization for Standardization \\
\hline LCA & Life cycle assessment \\
\hline LCA-Pro & Life cycle assessment software name \\
\hline LCI & Life cycle inventory \\
\hline ME & Marine eutrophication \\
\hline MT & Mega tonne \\
\hline Non-CST & Non- concentrated solar thermal technology \\
\hline ODP & Ozone depletion potential \\
\hline POCP & photo-oxidant creation potential \\
\hline PMF & Particulate matter formation \\
\hline TAP & Terrestrial acidification \\
\hline USGS & U.S. Geological Survey database \\
\hline WD & Water resource depletion \\
\hline WMO & World Meteorological Organization \\
\hline WSP & Water scarcity potential \\
\hline kg CO ${ }_{2}$ eq & Carbon dioxide equivalent \\
\hline
\end{tabular}




\section{References}

(JRC), I. for the E. and S. in the E.C.J.R.C., 2012. ILCD handbook, Http://Lct.Jrc.Ec.Europa.Eu/Assessment/Assessment/Projects. https://doi.org/10.278/33030

Acero, A.A.P., Rodríguez, C., Ciroth, A., 2015. LCIA methods Impact assessment methods in Life Cycle Assessment and their impact categories 1-22.

Adiansyah, J.S., Haque, N., Rosano, M., Biswas, W., 2017. Application of a life cycle assessment to compare environmental performance in coal mine tailings management. J. Environ. Manage. 199, 181-191. https://doi.org/10.1016/j.jenvman.2017.05.050

Althaus, H., Chudacoff, M., Hischier, R., Jungbluth, N., Osses, M., Primas, A., Hellweg, S., 2007. Life cycle inventories of chemicals. Ecoinvent data v2.0, Swiss Centre for Life Cycle Inventories. 1-957.

Althaus, H.J., Classen, M., 2005. Life cycle inventories of metals and methodological aspects of inventorying material resources in ecoinvent. Int. J. Life Cycle Assess. 10, 43-49. https://doi.org/10.1065/lca2004.11.181.5

Bartzas, G., Komnitsas, K., 2015. Life cycle assessment of ferronickel production in Greece. Resour. Conserv. Recycl. 105, 113-122. https://doi.org/10.1016/j.resconrec.2015.10.016

Burchart-Korol, D., 2013. Life cycle assessment of steel production in Poland: A case study. J. Clean. Prod. 54, 235-243. https://doi.org/10.1016/j.jclepro.2013.04.031

Burchart-Korol, D., Fugiel, A., Czaplicka-Kolarz, K., Turek, M., 2016. Model of environmental life cycle assessment for coal mining operations. Sci. Total Environ. 562, 61-72. https://doi.org/10.1016/j.scitotenv.2016.03.202

Chen, W., Geng, Y., Hong, J., Dong, H., Cui, X., Sun, M., Zhang, Q., 2018. Life cycle assessment of gold production in China. J. Clean. Prod. 179, 143-150. https://doi.org/10.1016/j.jclepro.2018.01.114

Cortez-Lugo, M., Riojas-Rodríguez, H., Moreno-Macías, H., Montes, S., Rodríguez-Agudelo, Y., Hernández-Bonilla, D., Catalán-Vázquez, M., Díaz-Godoy, R., Rodríguez-Dozal, S., 2018. Evaluation of the effect of an environmental management program on exposure to manganese in a mining zone in Mexico. Neurotoxicology 64, 142-151. https://doi.org/10.1016/j.neuro.2017.08.014

Curran, M.A., 2012. Life Cycle Assessment Handbook. https://doi.org/10.1002/9781118528372

DEE, 2017. Australian Energy Update. Aust. Gov. 2016, 27. https://doi.org/2203-8337

Ekman Nilsson, A., Macias Aragonés, M., Arroyo Torralvo, F., Dunon, V., Angel, H., Komnitsas, K., Willquist, K., 2017. A Review of the Carbon Footprint of $\mathrm{Cu}$ and $\mathrm{Zn}$ Production from Primary and Secondary Sources. Minerals 7, 168. https://doi.org/10.3390/min7090168

EPA, 2018. The Emissions \& Generation Resource Integrated Database (eGRID) Technical Support Document. US Environ. Prot. Agency 106.

European Commission -- Joint Research Centre -- Institute for Environment and Sustainability, 2010. International Reference Life Cycle Data System (ILCD) Handbook -- General guide for Life Cycle Assessment -- Detailed guidance, Constraints. https://doi.org/10.2788/38479

Farjana, S.H., Huda, N., Mahmud, M.A.P., 2019a. Impacts of aluminum production: A cradle to gate investigation using life-cycle assessment. Sci. Total Environ. 663, 958-970. https://doi.org/10.1016/j.scitotenv.2019.01.400

Farjana, S.H., Huda, N., Mahmud, M.A.P., 2019b. Life cycle analysis of copper-gold-lead-silver-zinc beneficiation process. Sci. Total Environ. 659, 41-52. https://doi.org/10.1016/j.scitotenv.2018.12.318

Farjana, S.H., Huda, N., Mahmud, M.A.P., 2019c. Life cycle assessment of cobalt extraction process. J. Sustain. Min. https://doi.org/10.1016/j.jsm.2019.03.002

Farjana, S.H., Huda, N., Mahmud, M.A.P., 2018a. Life-Cycle environmental impact assessment of mineral industries, in: IOP Conference Series: Materials Science and Engineering. https://doi.org/10.1088/1757-899X/351/1/012016

Farjana, S.H., Huda, N., Mahmud, M.A.P., Lang, C., 2019d. Impact Analysis of Gold-Silver Refining Processes Through Life-Cycle Assessment. J. Clean. Prod. https://doi.org/10.1016/j.jclepro.2019.04.166 
Farjana, S.H., Huda, N., Mahmud, M.A.P., Lang, C., 2018a. Towards sustainable TiO 2 production : An investigation of environmental impacts of ilmenite and rutile processing routes in Australia. J. Clean. Prod. 196, 1016-1025. https://doi.org/10.1016/j.jclepro.2018.06.156

Farjana, S.H., Huda, N., Mahmud, M.A.P., Lang, C., 2018b. Comparative Life-cycle Assessment of Uranium Extraction Processes in Australia. J. Clean. Prod. 202, 666-683. https://doi.org/10.1016/j.jclepro.2018.08.105

Farjana, S.H., Huda, N., Parvez Mahmud, M.A., 2018b. Environmental impact assessment of european non-ferro mining industries through life-cycle assessment, in: IOP Conference Series: Earth and Environmental Science. https://doi.org/. IOP Conference Series: Earth and Environmental Science, 154, [012019]. DOI: 10.1088/1755-1315/154/1/012019

Ferreira, H., Leite, M.G.P., 2015. A Life Cycle Assessment study of iron ore mining. J. Clean. Prod. 108, 1081-1091. https://doi.org/10.1016/j.jclepro.2015.05.140

Fogler, S., Timmons, D., 1998. An Overview of the ISO 14040 Life Cycle Assessment Approach and an Industrial Case Study. Argentum V.

Fugiel, A., Burchart-Korol, D., Czaplicka-Kolarz, K., Smoliński, A., 2017. Environmental impact and damage categories caused by air pollution emissions from mining and quarrying sectors of European countries. J. Clean. Prod. 143, 159-168. https://doi.org/10.1016/j.jclepro.2016.12.136

Furberg, A., Arvidsson, R., Molander, S., 2019. Environmental life cycle assessment of cemented carbide (WC-Co) production. J. Clean. Prod. 209, 1126-1138. https://doi.org/10.1016/j.jclepro.2018.10.272

Gan, Y., Griffin, W.M., 2018. Analysis of life-cycle GHG emissions for iron ore mining and processing in China-Uncertainty and trends. Resour. Policy 58, 90-96. https://doi.org/10.1016/j.resourpol.2018.03.015

Goedkoop, M., Oele, M., Vieira, M., Leijting, J., Ponsioen, T., Meijer, E., 2014. SimaPro Tutorial 89. https://doi.org/10.1142/S0218625X03005293

Gorman, M.R., Dzombak, D.A., 2018. A review of sustainable mining and resource management: Transitioning from the life cycle of the mine to the life cycle of the mineral. Resour. Conserv. Recycl. 137, 281-291. https://doi.org/10.1016/j.resconrec.2018.06.001

Grande, C.A., Blom, R., Spjelkavik, A., Moreau, V., Payet, J., 2017. Life-cycle assessment as a tool for eco-design of metal-organic frameworks (MOFs). Sustain. Mater. Technol. 14, 11-18. https://doi.org/10.1016/j.susmat.2017.10.002

Guimarães da Silva, M., Costa Muniz, A.R., Hoffmann, R., Luz Lisbôa, A.C., 2018. Impact of greenhouse gases on surface coal mining in Brazil. J. Clean. Prod. 193, 206-216. https://doi.org/10.1016/j.jclepro.2018.05.076

Haque, N., Norgate, T., 2015. Life cycle assessment of iron ore mining and processing, Iron Ore: Mineralogy, Processing and Environmental Sustainability. Elsevier Ltd. https://doi.org/10.1016/B978-1-78242-156-6.00020-4

Haque, N., Norgate, T., 2014. The greenhouse gas footprint of in-situ leaching of uranium, gold and copper in Australia. J. Clean. Prod. 84, 382-390. https://doi.org/10.1016/j.jclepro.2013.09.033

Haque, N., Norgate, T., 2013. Estimation of greenhouse gas emissions from ferroalloy production using life cycle assessment with particular reference to Australia. J. Clean. Prod. 39, 220-230. https://doi.org/10.1016/j.jclepro.2012.08.010

Hischier, R., Weidema, B., Althaus, H.-J., Bauer, C., Doka, G., Dones, R., Frischknecht, R., Hellweg, S., Humbert, S., Jungbluth, N., Köllner, T., Loerincik, Y., Margni, M., Nemecek, T., 2010. Implementation of Life Cycle Impact Assessment Methods Data v2.2 (2010). ecoinvent Rep. No. 3 176.

International Institute for Environment and Development, 2002. Appendix 2 : Environmental and Social Impacts of Mining. Glob. Biodivers.

JRC European commission, 2011. ILCD Handbook: Recommendations for Life Cycle Impact Assessment in the European context, Vasa. https://doi.org/10.278/33030

Khoo, J.Z., Haque, N., Woodbridge, G., McDonald, R., Bhattacharya, S., 2017. A life cycle assessment of a new laterite processing technology. J. Clean. Prod. 142, 1765-1777. 
https://doi.org/10.1016/j.jclepro.2016.11.111

Li, C., Bai, H., Lu, Y., Bian, J., Dong, Y., Xu, H., 2018. Life-cycle assessment for coal-based methanol production in China. J. Clean. Prod. 188, 1004-1017. https://doi.org/10.1016/j.jclepro.2018.04.051

Lima, F.M., Lovon-Canchumani, G.A., Sampaio, M., Tarazona-Alvarado, L.M., 2018. Life Cycle Assessment of the Production of Rare Earth Oxides from a Brazilian Ore. Procedia CIRP 69, 481486. https://doi.org/10.1016/j.procir.2017.11.066

Lodhia, S., Martin, N., 2014. Corporate Sustainability Indicators: An Australian Mining Case Study. J. Clean. Prod. 84, 107-115. https://doi.org/10.1016/j.jclepro.2014.05.050

Long, K.R., DeYoung, J.H., Ludington, S.D., 1998. Database of significant deposits of gold, silver, copper, lead, and zinc in the United States. Part A: Database description and analysis. Open-File Report 98-206A. US Geol. Surv. 1-60.

Ma, X., Ye, L., Qi, C., Yang, D., Shen, X., Hong, J., 2018. Life cycle assessment and water footprint evaluation of crude steel production: A case study in China. J. Environ. Manage. 224, 10-18. https://doi.org/10.1016/j.jenvman.2018.07.027

Marguerite, R., Tim, G., Maartje, S., James, L., Brad, R., Fabiano, X., Jonas, B., Annette, C., Joe, J., 2015. Best Practice Guide for Life Cycle Impact Assessment ( LCIA ) in Australia ALCAS Impact Assessment Committee. ALCAS Impact Assess. Comm.

Memary, R., Giurco, D., Mudd, G., Mason, L., 2012. Life cycle assessment: A time-series analysis of copper. J. Clean. Prod. 33, 97-108. https://doi.org/10.1016/j.jclepro.2012.04.025

Menoufi, K.A.I., 2011. Life Cycle Analysis and Life Cycle Impact Assessment methodologies: State of the art. Master Thesis $1-84$.

Mistry, M., Gediga, J., Boonzaier, S., 2016. Life cycle assessment of nickel products. Int. J. Life Cycle Assess. 21, 1559-1572. https://doi.org/10.1007/s11367-016-1085-X

Mudd, G.M., 2009. The Sustainability of Mining in Australia: Key Production Trends and Their Environmental Implications for the Future. https://doi.org/978-0-9803199-4-1

Mutchek, M., Cooney, G., Pickenpaugh, G., Marriott, J., Skone, T., 2016. Understanding the Contribution of Mining and Transportation to the Total Life Cycle Impacts of Coal Exported from the United States. Energies 9, 559. https://doi.org/10.3390/en9070559

Norgate, T., Haque, N., 2012. Using life cycle assessment to evaluate some environmental impacts of gold production. J. Clean. Prod. 29-30, 53-63. https://doi.org/10.1016/j.jclepro.2012.01.042

Norgate, T., Haque, N., 2010. Energy and greenhouse gas impacts of mining and mineral processing operations. J. Clean. Prod. 18, 266-274. https://doi.org/10.1016/j.jclepro.2009.09.020

Norgate, T., Haque, N., Koltun, P., 2014. The impact of uranium ore grade on the greenhouse gas footprint of nuclear power. J. Clean. Prod. 84, 360-367. https://doi.org/10.1016/j.jclepro.2013.11.034

Norgate, T.E., 2001. A Comparative Life Cycle Assessment of Copper Production Processes.

Norgate, T.E., Jahanshahi, S., Rankin, W.J., 2007. Assessing the environmental impact of metal production processes. J. Clean. Prod. 15, 838-848. https://doi.org/10.1016/j.jclepro.2006.06.018

Northey, S., Haque, N., Mudd, G., 2013. Using sustainability reporting to assess the environmental footprint of copper mining. J. Clean. Prod. 40, 118-128. https://doi.org/10.1016/j.jclepro.2012.09.027

Nunez, P., Jones, S., 2016. Cradle to gate: life cycle impact of primary aluminium production. Int. J. Life Cycle Assess. 21, 1594-1604. https://doi.org/10.1007/s11367-015-1003-7

Paraskevas, D., Kellens, K., Van De Voorde, A., Dewulf, W., Duflou, J.R., 2016. Environmental Impact Analysis of Primary Aluminium Production at Country Level. Procedia CIRP 40, 209-213. https://doi.org/10.1016/j.procir.2016.01.104

Parker, D.J., MNaughton, C.S., Sparks, G.A., 2016. Life Cycle Greenhouse Gas Emissions from Uranium Mining and Milling in Canada. Environ. Sci. Technol. 50, 9746-9753. https://doi.org/10.1021/acs.est.5b06072

PRé, 2018. SimaPro Database Manual Methods Library Colophon Title: SimaPro Database Manual Methods Library. https://doi.org/10.1017/CBO9781107415324.004 
Qi, C., Ye, L., Ma, X., Yang, D., Hong, J., 2017. Life cycle assessment of the hydrometallurgical zinc production chain in China. J. Clean. Prod. 156, 451-458. https://doi.org/10.1016/j.jclepro.2017.04.084

Ranängen, H., Lindman, A., 2017. A path towards sustainability for the Nordic mining industry. J. Clean. Prod. 151, 43-52. https://doi.org/10.1016/j.jclepro.2017.03.047

Raugei, M., Ulgiati, S., 2009. A novel approach to the problem of geographic allocation of environmental impact in Life Cycle Assessment and Material Flow Analysis. Ecol. Indic. 9, 1257-1264. https://doi.org/10.1016/j.ecolind.2009.04.001

Renzulli, P.A., Notarnicola, B., Tassielli, G., Arcese, G., Di Capua, R., 2016. Life cycle assessment of steel produced in an Italian integrated steel mill. Sustain. 8. https://doi.org/10.3390/su8080719

Ruan, S., Unluer, C., 2016. Comparative life cycle assessment of reactive $\mathrm{MgO}$ and Portland cement production. J. Clean. Prod. 137, 258-273. https://doi.org/10.1016/j.jclepro.2016.07.071

Santero, N., Hendry, J., 2016. Harmonization of LCA methodologies for the metal and mining industry. Int. J. Life Cycle Assess. 21, 1543-1553. https://doi.org/10.1007/s11367-015-1022-4

Stewart, M., Petrie, J., 2006. A process systems approach to life cycle inventories for minerals: South African and Australian case studies. J. Clean. Prod. 14, 1042-1056. https://doi.org/10.1016/j.jclepro.2004.08.008

Tan, R.B.H., Khoo, H.H., 2005. An LCA study of a primary aluminum supply chain. J. Clean. Prod. 13, 607-618. https://doi.org/10.1016/j.jclepro.2003.12.022

Teh, S.H., Wiedmann, T., Castel, A., de Burgh, J., 2017. Hybrid life cycle assessment of greenhouse gas emissions from cement, concrete and geopolymer concrete in Australia. J. Clean. Prod. 152, 312320. https://doi.org/10.1016/j.jclepro.2017.03.122

Tost, M., Hitch, M., Chandurkar, V., Moser, P., Feiel, S., 2018. The state of environmental sustainability considerations in mining. J. Clean. Prod. 182, 969-977. https://doi.org/10.1016/j.jclepro.2018.02.051

Van Genderen, E., Wildnauer, M., Santero, N., Sidi, N., 2016. A global life cycle assessment for primary zinc production. Int. J. Life Cycle Assess. 21, 1580-1593. https://doi.org/10.1007/s11367-016-11318

Weidema, B.P., Bauer, C., Hischier, R., Mutel, C., Nemecek, T., Reinhard, J., Vadenbo, C.O., Wernet, G., 2013. Data quality guideline for the ecoinvent database version $33,169$.

Weidema, B.P., Norris, G. a, 2002. Avoiding co-product allocation in the metals sector. ICMM Int. Work. Life Cycle Assess. Met.

Weng, Z., Haque, N., Mudd, G.M., Jowitt, S.M., 2016. Assessing the energy requirements and global warming potential of the production of rare earth elements. J. Clean. Prod. 139, 1282-1297. https://doi.org/10.1016/j.jclepro.2016.08.132

Westfall, L.A., Davourie, J., Ali, M., McGough, D., 2016. Cradle-to-gate life cycle assessment of global manganese alloy production. Int. J. Life Cycle Assess. 21, 1573-1579. https://doi.org/10.1007/s11367-015-0995-3

Wolf, M.A., Pant, R., Chomkhamsri, K., Sala, S., Pennington, D., 2012. The International Reference Life Cycle Data System (ILCD) Handbook, European Commission. JRC references reports. https://doi.org/10.2788/85727

WORLD ECONOMIC FORUM, 2015. Mining \& Metals in a Sustainable World 2050 1-44. https://doi.org/REF 250815

Zaimes, G.G., Hubler, B.J., Wang, S., Khanna, V., 2015. Environmental Life Cycle Perspective on Rare Earth Oxide Production. ACS Sustain. Chem. Eng. 3, 237-244. https://doi.org/10.1021/sc500573b

Zhang, L., Wang, J., Feng, Y., 2018. Life cycle assessment of opencast coal mine production: a case study in Yimin mining area in China. Environ. Sci. Pollut. Res. 25, 8475-8486. https://doi.org/10.1007/s1 1356-017-1169-6 